Review

\title{
The Emerging Roles of Autophagy in Human Diseases
}

\author{
Yuchen Lei ${ }^{1,2}$ and Daniel J. Klionsky ${ }^{1,2, * \mathbb{C}}$ \\ 1 Department of Molecular, Cellular and Developmental Biology, University of Michigan, \\ Ann Arbor, MI 48109, USA; yclei@umich.edu \\ 2 Life Sciences Institute, University of Michigan, Ann Arbor, MI 48109, USA \\ * Correspondence: klionsky@umich.edu
}

check for

updates

Citation: Lei, Y.; Klionsky, D.J. The Emerging Roles of Autophagy in Human Diseases. Biomedicines 2021, 9 , 1651. https://doi.org/10.3390/ biomedicines 9111651

Academic Editor: Alessandro Rimessi

Received: 27 September 2021

Accepted: 5 November 2021

Published: 9 November 2021

Publisher's Note: MDPI stays neutral with regard to jurisdictional claims in published maps and institutional affiliations.

Copyright: (c) 2021 by the authors. Licensee MDPI, Basel, Switzerland. This article is an open access article distributed under the terms and conditions of the Creative Commons Attribution (CC BY) license (https:// creativecommons.org/licenses/by/ $4.0 /)$.

\begin{abstract}
Autophagy, a process of cellular self-digestion, delivers intracellular components including superfluous and dysfunctional proteins and organelles to the lysosome for degradation and recycling and is important to maintain cellular homeostasis. In recent decades, autophagy has been found to help fight against a variety of human diseases, but, at the same time, autophagy can also promote the procession of certain pathologies, which makes the connection between autophagy and diseases complex but interesting. In this review, we summarize the advances in understanding the roles of autophagy in human diseases and the therapeutic methods targeting autophagy and discuss some of the remaining questions in this field, focusing on cancer, neurodegenerative diseases, infectious diseases and metabolic disorders.
\end{abstract}

Keywords: autophagy; cancer; infection; metabolism; neurodegeneration

\section{Introduction to Autophagy}

Autophagy is a conserved process from yeast to human, in which parts of the cytoplasm are transported to the lysosome (the vacuole in fungi and plants) for degradation and recycling. Three primary types of autophagy have been characterized, macroautophagy, microautophagy and chaperone-mediated autophagy (CMA) and the most prevalent form is macroautophagy (hereafter autophagy). The morphological hallmark of this form of autophagy is the formation of double-membrane vesicles, autophagosomes, which are the terminal product of phagophores. Following expansion and closure, the phagophore is now termed an autophagosome; this latter compartment ultimately fuses with the lysosome, releasing the cargo into the lumen of the degradative organelle where it is exposed to hydrolytic enzymes. The entire process of autophagy can be viewed as four steps: (1) initiation and nucleation of the phagophore; (2) expansion and closure of the phagophore to generate a completed autophagosome; (3) fusion with the lysosome; and (4) degradation and release/recycling of the autophagic cargos. Different autophagy-related (ATG) proteins are essential for each of these steps (Figure 1A).

Initiation begins with the activation of the ULK1 complex, including ULK1, ATG13, RB1CC1 and ATG101 in response to MTORC1 and AMPK [1]. The activated ULK1 complex will then phosphorylate and activate the class III phosphatidylinositol 3-kinase (PtdIns3K) complex, which contains PIK3C3/VPS34, PIK3R4/VPS15, BECN1, ATG14, NRBF2 and AMBRA1. The activated PIK3C3/VPS34 phosphorylates phosphatidylinositol (PtdIns) to produce a local pool of phosphatidylinositol-3-phosphate (PtdIns3P), which defines the region of phagophore initiation and recruits PtdIns3P effector proteins including WIPI2 and ZFYVE1/DFCP1 [2]. One model suggests that the phagophore is derived from a PtdIns3P-enriched ER region named the omegasome, followed by the recruitment of membrane sources for phagophore expansion, including ER exit sites [3], ER-mitochondria contact sites [4], the plasma membrane [5] and recycling endosomes [6], possibly via ATG9-containing vesicles, although the details of this process are still not fully understood. Another model, proposed by David Rubinsztein's group, suggests that the phagophore 
is evolved from RAB11-positive recycling endosomes [7]. Even though the origin of the autophagosome membrane is still under debate, the hierarchical assembly of ATG proteins is well accepted.

Following initiation, the phagophore expands through the action of two ubiquitin-like protein systems [8]. In the first system, ATG12 is conjugated with ATG5 via the E1-like enzyme ATG7 and the E2-like enzyme ATG10. The second ubiquitin-like system starts with the proteolytic processing of Atg8-family proteins, including the MAP1LC3/LC3 and GABARAP subfamilies, by the ATG4 protease; this is followed by conjugation to phosphatidylethanolamine (PE), in a process termed lipidation, via ATG7, the E2-like enzyme ATG3 and the E3-like ATG12-ATG5-ATG16L1 complex [8]. ATG16L1 binds to WIPI2 directly, allowing the lipidation to take place at the phagophore membrane [9]. The expansion and sealing of the phagophore generates the double-membrane autophagosome; during this step the ATG proteins disassociate from the autophagosome outer membrane [10].

Finally, the autophagosome outer membrane fuses with an endosome to form an intermediate compartment termed an amphisome and/or with a lysosome to form an autolysosome. The autophagosome inner membrane, together with the sequestered cargo will be exposed to the lysosomal hydrolases and degraded. The resulting small molecules are released back into the cytosol through membrane permeases for reuse or as catabolic substrates.

Autophagy can be selective, and several protein aggregates and organelles have been characterized as targets of selective autophagy [11]. This type of autophagy can be ubiquitin dependent, where the ubiquitinated cargo is captured by ubiquitin-binding receptors, which can also interact with Atg8-family proteins through LC3-interacting regions (LIRs) and recruit the cargo to the phagophore [8], but selective autophagy can also be ubiquitin independent. Selective autophagy is important for the clearance of damaged and superfluous organelles and misfolded or oxidized proteins, thereby playing a significant role in maintaining proper cell physiology; the dysregulation of selective autophagy is therefore associated with several diseases. Mitophagy is a critical quality control process to degrade damaged and superfluous mitochondria through selective autophagy to maintain a pool of functional organelles and avoid the harmful effects of excessive reactive oxygen species (ROS) that might otherwise be generated. In line with this function, dysregulation of mitophagy leads to multiple diseases [12]. For a better understanding of how selective autophagy is related to disease, here we provide a brief introduction about the mechanism of mitophagy (Figure 1B).

In yeast, Atg32, an outer mitochondrial membrane (OMM) protein, serves as the receptor recruiting Atg8, and Atg11 acts as the scaffold/platform for core Atg protein assembly [13-16]. Mammalian mitophagy is more complicated and occurs via the action of different components depending on the cell type and/or purpose; for example, mitochondrial removal during red blood cell erythropoiesis involves BNIP3L/NIX and is part of a normal developmental pathway [17]. The PINK1-PRKN pathway is one well-characterized mechanism of mitophagy. When mitochondria are compromised, the loss of the membrane potential stabilizes PINK1, a Ser/Thr kinase, on the OMM [18]. PINK1 recruits, phosphorylates, and activates PRKN, an E3 ubiquitin ligase [19-23]. At the same time, PINK1 phosphorylates ubiquitin [24], which will be conjugated to some OMM proteins. Ubiquitinated mitochondria are recognized by several receptors [25-28], joining them with LC3, and the mitochondria get sequestered by the growing phagophore. Besides; some OMM proteins such as BNIP3L and FUNDC1 can themselves function as the receptor [29,30]. Of note, PINK1 and PRKN are mutated in autosomal recessive Parkinson disease (PD) and their roles in mitophagy indicate the connection between mitophagy and PD, which will be discussed in detail in the following sections. 

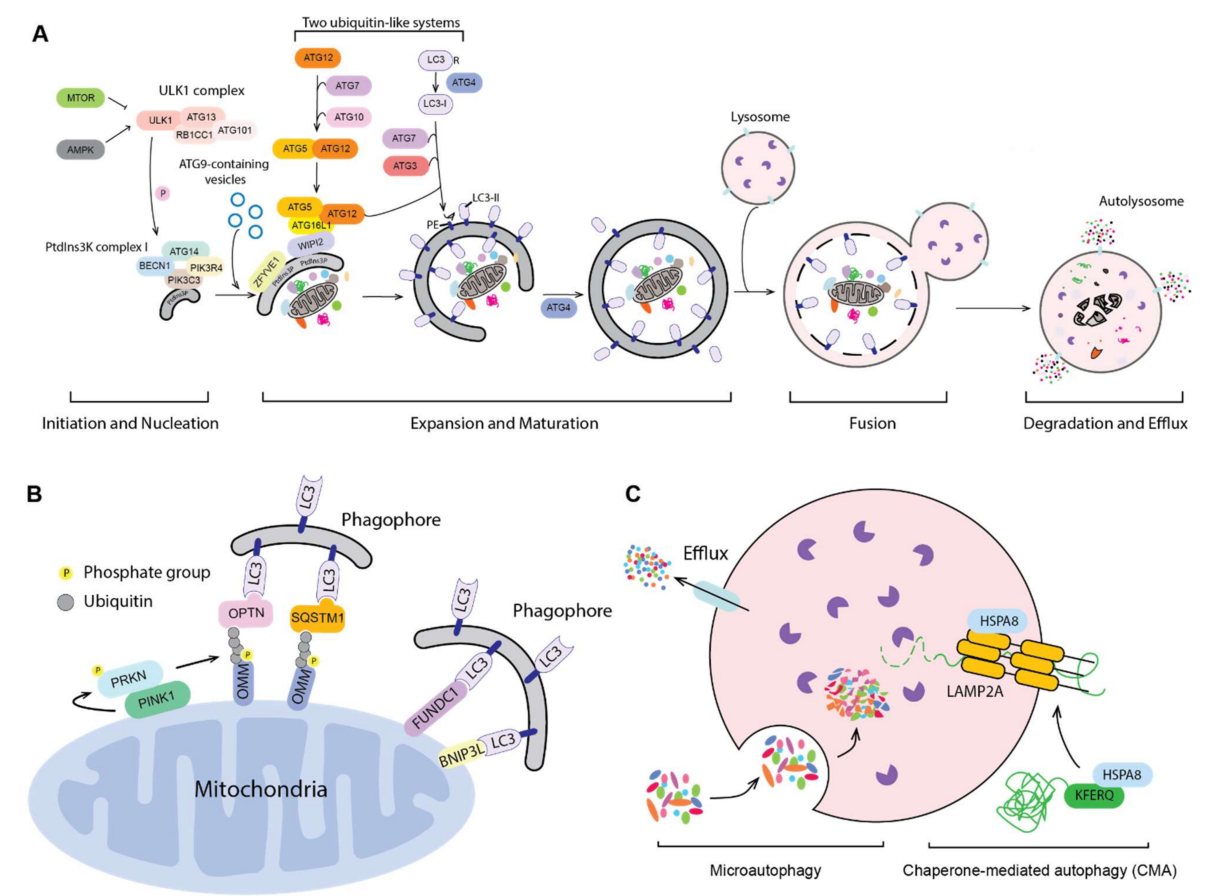

Figure 1. Three types of autophagy. (A) The mechanism of macroautophagy. Upon induction, the phagophore nucleates and expands to sequester cytoplasmic substrates randomly or selectively. Upon completion, the phagophore closes and forms a double-membrane autophagosome, which fuses with an endosome (not shown) and/or a lysosome; the autophagic cargos are degraded and the breakdown products are released back into the cytosol. The sequence shown for the LC3B C terminus is for the mouse protein. (B) PINK1- and PRKN-mediated and receptor-mediated mitophagy. Upon mitochondrial damage, PINK1 recruits and phosphorylates PRKN on the outer mitochondrial membrane (OMM). PRKN mediated the ubiquitination of OMM proteins, which then bind to autophagy receptors, targeting the mitochondria to a phagophore via interaction with an Atg8-family protein. Additionally, OMM proteins such as FUNDC1 and BNIP3L can serve as the mitophagy receptors. (C) Microautophagy and chaperone-mediated autophagy (CMA). During microautophagy, the lysosome membrane rearranges and forms a lumenal vesicle-containing autophagic substrates, which will be degraded within the lysosome. CMA starts from the recognition of a KFERQ-like motif in the substrate protein by HSPA8. HSPA8 facilitates the transport of substrates into the lysosome through the action of LAMP2A and lumenal HSPA8.

The biggest morphological difference between macroautophagy and the other two major forms of autophagy, microautophagy and CMA (Figure 1C), is that autophagosome formation is not involved-in both cases, sequestration of the cargo occurs directly at the lysosome membrane. In microautophagy, the lysosome membrane undergoes a rearrangement by protrusion or invagination and engulfs the autophagic cargos, resulting in a lumenal vesicle that is degraded along with the autophagic substrates [31]. Microautophagy is proposed to participate in several cellular processes including organellar quality control, but its role in human diseases remains unclear [32]. During CMA, individual proteins bearing a KFERQ-like motif bind to the cytosolic chaperone HSPA8/HSC70. The protein unfolds and then translocates into the lysosome via the receptor LAMP2A (lysosomal associated membrane protein 2A) and lumenal HSPA8, in addition to other components [33]. In the cell, approximately $40 \%$ of proteins contain a KFERQ-like motif [33], indicating that CMA functions as an important lysosome-dependent protein degradation pathway. Along these lines, CMA is involved in many different human pathologies, particularly in neurodegenerative diseases [33-35], which will be discussed in later sections.

Autophagy was first defined as a way for the cell to deal with environmental stresses such as starvation, hypoxia and ER stress; the macromolecular products of the degradation 
process are released back into the cytosol for reuse and energy replenishment. However, under normal conditions, autophagy also plays a critical role in controlling cellular homeostasis through clearing misfolded or oxidized proteins and damaged or superfluous organelles. The physiological relevance of autophagy has been highlighted over the past two decades, including its role in development [36] in the maintenance of stem cells $[37,38]$ and in the immune system [39]. Given the importance of autophagy in both normal physiological and stress conditions, it is not surprising to see that dysregulation of autophagy leads to a diseased stated due to alterations in these critical physiological processes and in the response to environmental stress; accordingly, modulation of autophagy can help in recovery from the diseased state. In this review, we discuss the role of autophagy in four types of disease and the corresponding autophagy-targeting therapies.

\section{Autophagy and Cancer}

Autophagy plays dual roles in cancer regulation. Autophagy can be tumor-suppressive with its ability to clear oncogenic proteins and damaged organelles. Alternatively, autophagy, as a primary mechanism for tolerance and cell survival under stress conditions, can be used for tumor cells to promote their growth and progression (Figure 2). In this section, we briefly discuss how autophagy affects tumor from these two perspectives.

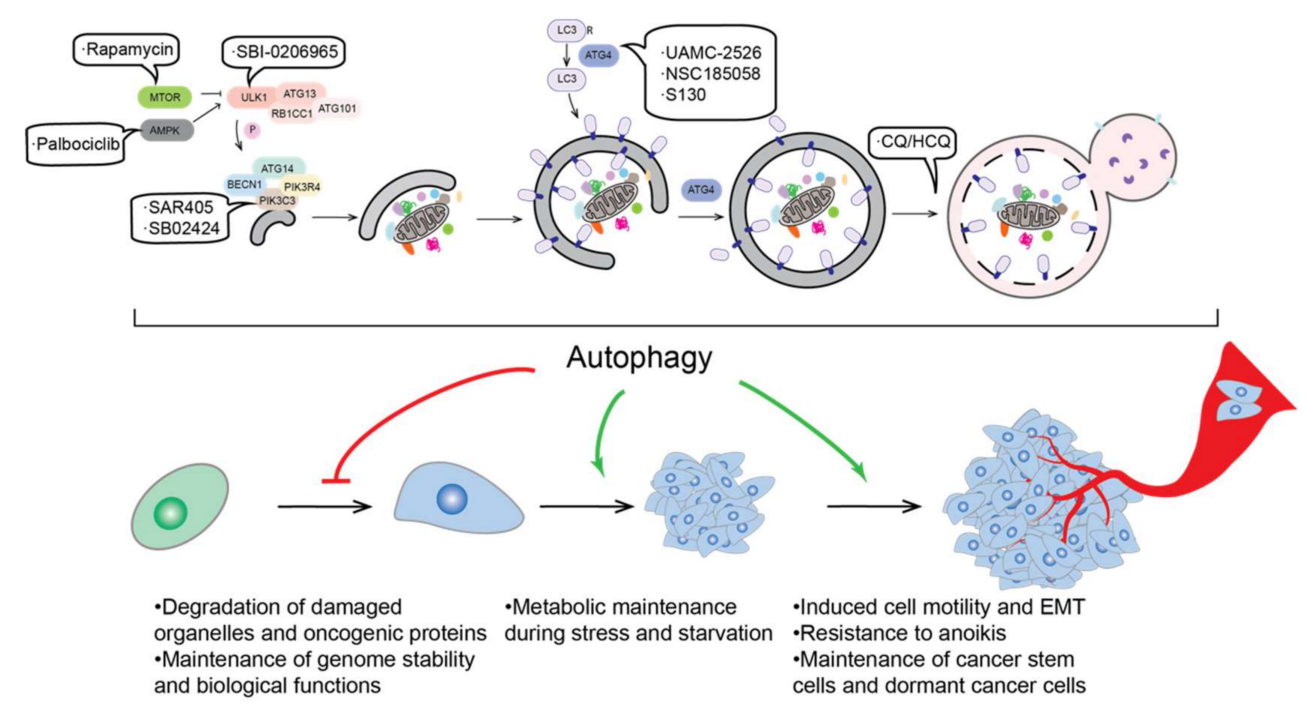

Figure 2. Autophagy in tumor progression and autophagy-targeting cancer therapy. Autophagy has been proposed to inhibit malignant transformation through different mechanisms, including the degradation of damaged organelles and oncogenic proteins and the maintenance of genomic stability and biological functions. After the tumor forms, autophagy basically supports tumor progression mainly through regulating metabolic process during stress or starvation. Tumor-supporting functions of autophagy are also reflected from its ability of promote cell motility, EMT and resistance to anoikis and to maintain cancer stem cells and dormant cancer cells. Because controversial conclusions exist, we only present what most studies indicate. Autophagy modulation could have the ability to treat cancers, and drugs targeting different steps of autophagy have been proposed as potential anticancer therapeutic approaches.

\subsection{Autophagy and Tumor Suppression}

In 1999, a study from Beth Levine's lab demonstrated the role of BECN1 as a tumor suppressive factor, first linking autophagy with cancer [40]. Several subsequent studies have connected BECN1 with different types of cancer, such as hepatocellular carcinoma, gastric cancer and lymphoma [41-43]. The fact that the heterozygous disruption of BECN1 results in an increased frequency of spontaneous malignancies and decreased autophagy $[44,45]$ indicates that autophagy functions as a tumor suppression mechanism. In line with this 
hypothesis, several BECN1-interacting proteins function as tumor suppressors. Frameshift and truncation mutations in UVRAG, an important BECN1 interactor during autophagosome and lysosome fusion [46], are found in cancer cells and also lead to reduced autophagy and increased tumorigenicity [47,48]. SH3GLB1/BIF1, which joins the BECN1 complex through UVRAG, is also a tumor suppressor; loss of SH3GLB1 inhibits autophagy while promoting tumorigenesis [49]. Another important protein for the BECN1-containing complex activity, AMBRA1 [50], is reported to act as a tumor suppressor via facilitating the degradation of the proto-oncogene MYC/c-Myc [51]. AMBRA1 also controls the cell cycle from the $G_{1}$ to $S$ phase through mediating D-type cyclin degradation, which reduces DNA replication stress, maintains genome integrity and therefore suppresses tumorigenesis [52].

Mutations of core ATG genes, including ATG2B, ATG5 and ATG9B, are also found in cancers, especially those with high microsatellite instability (MSI), which is characterized by the insertion or deletion in the repeated DNA sequence due to deficient DNA mismatch repair $[53,54]$. Additionally, the frameshift mutation of UVRAG mentioned above is also found in gastric carcinomas with MSI [47]. In addition to the core ATG genes, frameshift mutations in VPS33A, which functions during the fusion between autophagosomes and lysosomes [55], are also found in colorectal cancer cells with high MSI [56]. However, how these mutations affect autophagy and tumor progression has not been fully examined. In addition, mutation at an ATG5 splice site has been reported in a prostate cancer cell line, which prevents ATG12 conjugation and leads to the degradation of ATG12 and ATG16L1, thus inhibiting autophagy [57]. Of note, even though ATG genes have a more than $25 \%$ mutation rate in gastric and colorectal cancers with MSI [54], a study analyzing 11 different types of cancer supports the idea that core autophagy machinery is not highly targeted by single-nucleotide mutations [58]. This finding could reflect the necessity of an intact autophagy pathway for tumor growth. In line with this, the ablation of autophagy results in more benign diseases rather than invasive cancer [59-62], indicating that autophagy inhibits tumor initiation but is required for further progression, which will be discussed in the next subsection.

Most of the studies mentioned above focus on autophagy activity, but not its selectivity. Recently, by mapping mutations in cancers to LIR-motif-containing proteins, Han et al. found more than 200 potential LIR-motif associated mutations (LAMs) in 148 different proteins [63]. They further examined STBD1, a glycogen autophagy receptor, and found that it inhibits tumor growth and that the cancer-associated LAM inhibits its interaction with LC3 and abolishes its cancer-suppressing capability, drawing a connection between glycogen autophagy and tumor suppression [63]. Other proteins of interest were identified from this analysis. For instance, some core ATG genes were identified in the screen, including ATG4B, ATG2B, ATG5 and ATG9A, and the mutation in ATG4B decreases its interaction with LC3. How these mutations affect autophagy and how the potential change in autophagy is associated with cancer need further examination. Additionally, some proteins not in the core autophagy machinery are predicted to contains LAMs, such as BRAF, a defined oncogenic protein [64]. Can these proteins be the cargos or receptors of selective autophagy? Do these mutations in LIR motifs function as a way to escape autophagic degradation and result in cancer? The answer to these questions will shed more light on how autophagy suppresses tumors.

\subsection{Autophagy and Tumor Promotion}

Cancer cells often encounter a stressful environment lacking both nutrients and oxygen, especially in the interior region of a tumor. Because autophagy is an important pathway for cell survival under stress conditions, it is not surprising to see that autophagy supports tumor maintenance and growth. Elevated autophagy is discovered in many types of cancers, suggesting the important role of autophagy in tumor promotion $[65,66]$. In line with this observation, attenuated tumor growth has been found when autophagy is inhibited [61,62,67-72]. One important mechanism by which autophagy promotes tumor growth is to sustain metabolic plasticity [73]. Autophagy can recycle macromolecules and 
provide metabolic substrates to sustain energy homeostasis [74-76] and ablated autophagy in STK11/LKB1-deficient cells leads to insufficient amino acids for mitochondria energy production, excessive fatty acid oxidation and energy crisis [77]. Furthermore, blockage of autophagy also leads to the accumulation of ROS, resulting in DNA damage, which is another possible reason for impaired cancer cell growth after autophagy inhibition [67].

Importantly, even though tumor promotion through autophagy is discovered in many cancers, it depends on the genotype of the cancer cells, or more specifically, the expression of TP53/p53. In both breast cancer and non-small-cell lung cancer, inhibition of autophagy only impairs the growth of the cancer cells expressing TP53 [78,79], indicating that TP53 inhibits tumor growth when autophagy is inhibited. However, whether TP53 determines the consequence of autophagy inhibition is controversial when it comes to pancreatic ductal adenocarcinoma $[60,80]$. Overall, it seems unlikely that inhibiting autophagy can be used as a general therapeutic approach, but there may be patient-specific applications depending on the genotype of the cancer cells.

\subsection{Autophagy and Tumor Metastasis}

Metastasis is one of the hallmarks of cancer and causes most cancer-related deaths [81]. Increased expression of autophagy associated genes is correlated with a more aggressive and invasive phenotype [82,83], suggesting that autophagy primarily promotes tumor metastasis.

\subsubsection{Autophagy and Cancer Cell Motility}

The very first step of metastasis is to gain motility and invasiveness to allow migration from the primary tumor site. Cell migration is critical at the early stage of metastasis and turnover of focal adhesions (FAs) is important during this process [84]. FA turnover is promoted by autophagy, though degrading FA proteins such as PXN (paxillin) $[85,86]$. Additionally, a recent study shows that the deletion of RB1CC1 or ATG5 leads to different FA morphologies, but they both result in reduced cell motility [87]. However, during energy starvation, RB1CC1 is activated by ULK1 and inhibits focal adhesion kinase PTK2/FAK, leading to reduced cell motility and tumor metastasis [88]. Together, these studies suggest that energy-starvation-induced autophagy may inhibit cancer cell metastasis, but basal autophagy is necessary for cancer cells to gain motility and invasiveness.

NBR1 is also suggested to mediate the autophagy-dependent disassembly of FA proteins through its interaction with FA proteins and LC3 [89], suggesting the selective degradation of FA proteins. However, which FA protein or proteins are the cargo of NBR1-mediated selective autophagy is unknown. Additionally, because NBR1 contains a ubiquitin-binding domain, ubiquitination of FA proteins may participate in this process, but additional studies are needed to confirm this hypothesis. In a recent study, researchers from Jayanta Debanth's lab reported that in breast cancer, autophagy inhibition promotes aberrant NBR1 accumulation, which induces the expression of basal epithelial markers and metastatic outgrowth [90]. Together, these studies indicate that autophagy may have distinct roles at different stages of metastasis, supporting cell matrix detachment in an early step, but suppressing metastatic outgrowth at later stages, and NBR1 seems to be a critical protein in both types of regulation. This idea is in line with some discoveries that metastases have a higher level of autophagy than the primary tumor cells, and early cancer metastases have the highest LC3 level [91]. However, many questions remain to be answered: What are the downstream targets of NBR1 when it promotes metastatic outgrowth? Overexpressing NBR1 promotes SQSTM1 accumulation and phosphorylation in liquid-like bodies [92] and SQSTM1-mediated activation of NFE2L2/NRF2 provides hepatocellular carcinoma cells proliferation potency [93]. In addition, aberrant regulation of NFE2L2 is correlated with high-level resistance to anticancer drugs [94]. Therefore, NBR1 accumulation by autophagy inhibition may help tumor metastases outgrowth through SQSTM1 and NFE2L2, but this still needs further investigation. Additionally, how NBR1 is 
regulated and plays different roles in cancer cell motility and metastases outgrowth and whether NBR1 is involved in other cancers need further investigation.

Epithelial-mesenchymal transition (EMT), a pro-metastatic process wherein epithelial cells gain mobility and invasiveness to become mesenchymal stem cells, is also regulated by autophagy [95]. Autophagy, on the one hand, promotes EMT [96-99]; however, how this happens remains controversial. Some studies indicate that autophagy regulates EMT in a TGFB-dependent manner [96], but others point out that TGFB-induced EMT partially depends on autophagy [100]. Therefore, which pathway is upstream remains unclear. Additionally, because TGFB can activate autophagy [101], whether there is a positive loop between these two factors to promote EMT is worth examining. On the other hand, autophagy could inhibit EMT via selective degradation of the transcriptional repressor SNAI1/Snail and inhibiting SQSTM1-dependent stabilization of the transcription factor TWIST1 [102-104]. These discrepancies in how autophagy regulates EMT, whether in the same direction but via different mechanisms or even in opposite directions, indicate the importance of figuring out if autophagy is directly or indirectly linked to EMT. If directly, does it act in parallel with the known EMT signaling pathways? If indirectly, apart from TGFB, are there interactions between autophagy and EMT pathways that contribute to cancer cell EMT? This is a pertinent questions because, besides the TGFB-SMAD pathway, other types of cell signaling, including PI3K-AKT, MAPK, and RHO GTPase cascades [105] are also key mediators to activate the EMT and they all have close interactions with autophagy [106]; thus, it is possible that autophagy either acts in parallel with one or more of these pathways or they function together to form a network regulating cancer cell EMT.

\subsubsection{Autophagy and Resistance to Anoikis}

Once cancer cells enter the circulatory system, the disassociation from the extracellular matrix (ECM) leads to anoikis, a form of programmed cell death [107]. When detachment from the ECM occurs, oxidative stress activates EIF2AK3/PERK, which induces autophagy through promoting the expression level of some essential ATG genes [108], activating AMPK and inhibiting MTOR complex 1 (MTORC1) [109] and the induced autophagy protects the cell from anoikis $[108,110]$. Besides EIF2AK3, IKK also induces autophagy but via an MTORC1-independent pathway [111]. In a recent study, MTDH/AEG-1 is reported to promote anoikis resistance, which partially depends on autophagy [112].

Even though different signals have been revealed to induce autophagy after ECM detachment, the mechanism downstream of autophagy induction remains unclear. Proteins from the BCL2 family are key players in anoikis [113] and the close connection between autophagy and apoptosis implies that autophagy may regulate anoikis through BCL2-family proteins [114]. During anoikis, BCL2L11/BIM, a BCL2-family pro-apoptotic protein, is translocated to mitochondria and promotes the assembly of BAX-BAK1 oligomers to induce apoptosis [113]. BCL2L11/BIM can form a complex with BECN1 [115]. Therefore, upon autophagy induction, the increasing level of BECN1 may be able to sequester BCL2L11 from mitochondria, thus inhibiting cell death. Beyond the direct interaction with these BCL2-family proteins, autophagy may indirectly inhibit anoikis. MAPK1 is critical for apoptosis prevention [116] and autophagy may activate MAPK1 function through phosphorylation [117]. Therefore, it is possible that autophagy promotes anoikis resistance through its regulation of MAPK1; however, the precise mechanism needs further examination.

\subsection{Autophagy and Cancer Stem Cells}

Cancer stem cells (CSC) are a subpopulation of cancer cells, which are similar to normal stem cells, but proposed to be critical for tumor metastasis because of their high mobility and self-renewal ability [118]. Autophagy is upregulated in a variety of CSCs and found to be important for CSC survival and maintaining stemness, which encompasses the fundamental properties of stem cells such as self-renewal and generating daughter cells [119-121]. Previously, IL17B was shown to be overexpressed in breast cancer tissue and inversely correlate with breast cancer patient survival rate [122], and a recent study 
indicates that IL17B induces autophagosome formation in gastric cancer CSCs; in contrast, autophagy inhibition through ATG7 deletion inhibits IL17B-induced self-renewal, which draws a connection between autophagy and CSC maintenance [123]. The ability of autophagy to maintain CSCs may provide an explanation as to why some ATG genes, such as $L C 3 B, G A B A R A P$ and $A T G 5$, have been found to correlate with poor prognosis [124,125].

Autophagy supports CSC stemness through several downstream pathways. First, in breast cancer, autophagy supports stemness through inducing the secretion of IL6 [126], which is important for stemness maintenance [127]. Second, EGFR-STAT3 and TGFBSMAD signaling pathways are found to act downstream of autophagy to sustain CSC stemness [128]. Third, in gastric CSCs, a higher expression level of FOXA2 is sustained by autophagy [129], which promotes cell proliferation and maintain CSC stemness [130], and overexpressing FOXA2 partially rescues the decreased self-renewal ability when autophagy is inhibited [129]. Finally, autophagy can augment cell stemness through degrading ubiquitinated TP53 [125,131]. All the studies mentioned above indicate that autophagy positively regulates CSC. However, this observation does not mean that continually higher autophagy activity is better for CSCs. A study from Shashi Gujar's lab demonstrates that autophagy promotion and suppression both result in a decrease in pluripotency and an increased differentiation or senescence of CSCs [132], indicating that a proper autophagy level is essential to sustain the stemness of CSCs.

\subsection{Autophagy and Dormant Cancer Cells}

One reason tumors are difficult to treat is the existence of dormant cancer cells, which refers to some cancer cells that have arrested growth but are able to retain proliferative capacity and lead to subsequent tumor growth $[133,134]$. Even though dormant cells have similarities to CSCs such as drug resistance, fundamental differences exist. CSCs are considered as "slow cycling cells" whereas dormant cancer cells undergo cell cycle arrest. In addition, CSCs express stemness marker genes and are at the apex of the differentiation hierarchy. However, dormant and activated cancer cells are at the same differentiation stage and the switch between dormancy and activation is reversible [135].

Many independent studies show that under different dormancy induction conditions, cancer cells show a higher autophagy activity [136], suggesting that autophagy may be critical to maintain the survival of these dormant cells. A majority of ovarian cancer patients develop tumor recurrence, possibly due to the existence of dormant cancer cells [137], and therefore, ovarian cancer becomes a major model to study cancer dormancy. DIRAS3/ARHI usually has a lower expression level in ovarian cancer cells, but the re-expression of DIRAS3 induces autophagy and these cells keep dormant when they grow in a mouse model. The inhibition of autophagy through chloroquine (CQ) treatment leads to a reduced regrowth of these dormant cells in the mouse model, indicating that DIRAS3-induced autophagy is critical for the survival of dormant cancer cells $[138,139]$. Another study shows that AKT inhibition induces dormancy-like ovarian cancer cells. Under this condition, autophagy activity is increased, and autophagy inhibition will reduce cell viability [140]. Interestingly, DIRAS3-induced autophagy seems to play a different role in vitro and in vivo. As mentioned previously, expressing DIRAS3 in xenograft leads to dormant cancer cells, whereas in cell culture, autophagy induction through DIRAS3 leads to cell death [141]. This difference may come from a more complicated in vivo system than the in vitro cell culture and the interaction between the cancer cell and its microenvironment may contribute to the choice between apoptosis or quiescence. Beyond ovarian cancer, cancer cell dormancy promotion by autophagy is seen in many other cancer types as well. Dormant breast CSCs are highly autophagic [142], which supports cell survival during dormancy [143]. In glioblastoma, autophagy reprograms cancer cell metabolism and promotes cancer cell quiescence [144].

Inhibition of autophagy facilitates cancer cell escape from the dormant state [142,145]. PFKFB3, which may promote cancer cell metastasis [146], could be a key factor in this process. PFKFB3 is an autophagy substrate and an elevated level of PFKFB3 when au- 
tophagy is impaired may explain the induced tumor recurrence [142]. Recently, MIR27A was reported to ameliorate chemoresistance of breast cancer cells and, at the same time, inhibit autophagy [147], further suggesting that impairment of autophagy leads to cancer cell emergence from the dormant state.

Whether autophagy could be a target to deal with dormant cancer cells having high drug resistance needs a more careful examination. Is awakening dormant tumors via inhibiting autophagy a good way to make them more sensitive to chemotherapy and preventing tumor recurrence? A recent study suggests that treating DIRAS3-overexpressing ovarian dormant cancer cells with crizotinib further increases autophagy and induces apoptosis, and treating mice carrying DIRAS3-expressing ovarian cancer cells with crizotinib prolongs life span [148], even though, as mentioned above, DIRAS3-indcued autophagy supports dormant cancer cell survival. These findings suggest that autophagy may have dual roles in sustaining tumor dormancy and that inducing autophagy to an improperly high level may also become a way to eliminate dormant cancer cells.

\subsection{Autophagy and Cancer Therapy}

As noted above, autophagy can suppress or promote tumors, indicating that modulating autophagy could be a way to treat cancer. CQ and its derivate hydroxychloroquine (HCQ), which impairs autophagosome fusion with a lysosome [149], are two autophagy inhibitors that have been approved by the FDA. CQ treatment inhibits tumor growth both in vitro and in vivo [150-152]. Additionally, CQ/HCQ sensitizes cancer cells to chemotherapy, so they are usually used together with other drugs [153], such as temozolomide in solid tumors and melanoma [154], bortezomib in myeloma [155], and gemcitabine in pancreatic ductal adenocarcinoma [156]. Of note, autophagy-independent effects may occur when treating cancer cells with $C Q$, but these effects still suggest $C Q$ may be a promising compound to treat cancer. For instance, CQ-induced blood vessel normalization, which does not rely on autophagy, restrains tumor invasion and metastasis [157].

Even though the clinical trial of CQ/HCQ is promising, there are still many concerns or limitations in CQ/HCQ application. First, a study culturing three different human cancer cell lines at acidic $\mathrm{pH}$ found that autophagic flux is not inhibited by CQ under this condition [158], suggesting that CQ may be not effective in the tumor region with an acidic microenvironment. Second, the results of CQ administration may be different depending on the tumor background. For instance, Maycotte et al. found that breast cancer cells with high STAT3 activity are more sensitive to autophagy inhibition than those with lower STAT3 activity [159], indicating CQ application may not be effective in some breast cancer subtypes. Third, as mentioned, the role of autophagy in tumor growths depends on cancer cell genotype [80], which may potentially lead to different CQ/HCQ effects.

Several inhibitors targeting the early steps of autophagy are also proposed to be potential drugs to treat cancers (Figure 2), such as the ULK1 inhibitor SBI-0206965 [160], the PtdIns3K inhibitors SAR405 and SB02424 [161,162] and the ATG4B inhibitors UAMC2526 [163], NSC185058 [164], and S130 [165]. These molecules have not gone into clinical trial, but their induction of cancer cell death or sensitivity to chemotherapy highlights their potential to treat cancers.

Because of the dual roles of autophagy in cancer, some autophagy activators are also suggested in cancer therapy. Rapamycin, a commonly used MTOR inhibitor has been proposed to inhibit tumor growth in many cancer types [166,167]. Palbociclib, an AMPK activator, is reported to increase both autophagy and apoptosis in hepatocellular carcinoma [168]. However, the usage of autophagy activators is not as common as that of inhibitors [153].

Even though the studies summarized above show attractive and promising results for the use of autophagy inhibitors or activators to treat cancer, important questions remain. First, it is not known which step of autophagy should be modulated to achieve a better result. Similarly, which autophagy-associated protein is the best target should be carefully examined because these proteins are also involved in other processes. For example, PIK3C3, 
PIK3R4 and BECN1 can form complexes with either ATG14 (complex I) or UVRAG (complex II), so PIK3C3 is involved not only in autophagy but also endosomal trafficking [169], and the PtdIns3K inhibitor SAR405 compromises both pathways [161]. To alleviate the risk of side effects due to the simultaneous influence on other pathways, drugs targeting more autophagy-specific proteins are needed. Recently, through a screening of more than 2000 molecules, researchers found 19 molecules that interrupt the interaction of BECN1 and ATG14, inhibit the formation of complex I and impair autophagy but not endosomal trafficking [170]. Whether these chemicals, which are more specifically targeting autophagy compared with the other PIK3C3 inhibitors, could have better effects on cancer therapy is worth further assessing. Autophagy also has a complicated crosstalk with other pathways, including cell death and cell migration. Therefore, the modulation of autophagy may lead to alternations of these fundamental cellular pathways, leading to a lower efficiency in tumor elimination or side effects.

Second, modulating autophagy may have different impact on cancer cells and other cells in the tumor microenvironment. While inhibiting autophagy may slow cancer cell growth, autophagy is also needed for other cells in the tumor microenvironment, especially for immune cell development and function [171,172]. Therefore, an expected result may not be achieved if these autophagy inhibitors are simply targeted to the general area of a tumor due to their influence on other neighboring cells.

Third, autophagy plays different roles during the progression of tumors, and even within metastasis, as mentioned above, autophagy has dual roles, inducing detachment but inhibiting outgrowth $[89,90]$, suggesting that it may not be a good idea to use only one compound that either induces or inhibits autophagy. Therefore, different drugs may be used based on the tumor stage and the background of the cancer cells.

Finally, whether cancer cells can develop autophagy inhibition resistance is worth considering. In the clinical trial of the combination of CQ and bortezomib, $45 \%$ of the patients are reported to have a period of stable disease [155], suggesting that cancer cells may develop some compensatory mechanism to deal with autophagy inhibition. Two recent studies indicate that knocking out several ATG genes, in both cancer cells and normal cells, leads to an increased expression of NFE2L2, a master transcription regulator, which increases proteasome production even though those proteosomes are not as effective as those in WT cells possibly due to the lack of autophagy [173,174]. The upregulation of the proteasome pathway may possibly make up for the loss of autophagy to maintain homeostasis. These autophagy-deficient cells with high NFE2L2 expression are sensitive to proteasome inhibition [173], but the clinical trial mentioned above involves the combination of autophagy and proteasome inhibitor [155]. Therefore, it is possible that some other pathways are also altered to circumvent the loss of autophagy. There are not many studies focusing on whether or how cancer cells compensate for autophagy inhibition, but exploring further into this aspect will help us optimize the efficiency and evaluate the long-term effect of autophagy-based cancer treatment.

\section{Autophagy and Neurodegenerative Diseases}

One hallmark of neurodegenerative diseases is the abnormal accumulation of certain neuroproteins. Because autophagy is critical for the degradation of protein aggregates and maintaining cellular homeostasis, it is not surprising to see that autophagy has a close connection with neurodegeneration: autophagy is responsible for the clearance of accumulated proteins, and this role is particularly important in non-dividing cells. In this section, we will discuss the role of autophagy in Parkinson, Alzheimer, and Huntington diseases.

\subsection{Parkinson Disease}

$\mathrm{PD}$ is characterized by the progressive loss of dopaminergic neurons of the substantia nigra, which is accompanied by the accumulation of SNCA / $\alpha$-synuclein in the form of Lewy bodies and Lewy neurites [175]. From genome-wide association studies (GWAS), 
great advances have been made in recent decades with the identification of monogenetic causes of PD, including mutations in SNCA, LRRK2, PRKN, and PINK1 [176,177].

SNCA is a substrate of CMA [178], and, consistent with this fact, boosting CMA decreases SNCA levels and protects cells from wild-type SNCA-induced neurotoxicity [179]. The SNCA accumulation and neurotoxicity in PD patients may result from two factors related to CMA. First, PD-associated mutant SNCA, A53T and A30P, are degraded by CMA less efficiently because they bind to the lysosome but cannot be translocated into the lysosomal lumen, which, at the same time, inhibits the degradation of other CMA cargos and increases cell toxicity $[180,181]$. Second, the expression level of essential CMA proteins, such as LAMP2A and HSPA8, decreases significantly in PD patient brains [182-184]. In addition, the PD-associated UCHL1 ${ }^{193 M}$ mutation facilitates interaction with LAMP2A, thus inhibiting CMA [185].

Besides CMA, SNCA is degraded through macroautophagy in neuronal cells [178] and particularly, via selective-autophagy mediated by SQSTM1 as the receptor in microglia [186]. At the same time, SNCA regulates autophagy. Overexpression of SNCA inhibits autophagy via RAB1, which further leads to the mislocalization of ATG9 [187]. Overexpression of PD-associated mutant $\mathrm{SNCA}^{\mathrm{E} 46 \mathrm{~K}}$ impairs autophagosome formation through the inactivation of the MAPK8/JNK1-BCL2 pathway [188]. One recent study, expressing human SNCA in Drosophila, found that SNCA impairs macroautophagy through stabilizing the actin cytoskeleton, which inhibits the fusion between lysosomes and autophagosomes [189]. Even though SNCA is a target of autophagy, SNCA aggregates are not easily degraded by autophagy and inhibit this process by impairing autophagosome clearance [190]. Autophagy is not only responsible for the degradation of SNCA, but also affects its cell-to-cell transmission [191]. Several studies indicate that the blockage of autophagy induces SNCA secretion through exosomes [192-194], which reduces cell death, but creates a microenvironment with an inflammatory and neurotoxic response [194]. Additionally, the secreted SNCA will be taken up by other neurons and act as a seed for aggregation in the recipient cells [195].

LRRK2 mutations are one of the most common causes of PD. In most cases of LRRK2associated PD, the protein has the G2019S mutation and the cells display the SNCA aggregates as Lewy bodies and undergo cell death [196]. Similar to SNCA, LRRK2 is another substrate of CMA, but the LRRK2 ${ }^{\mathrm{G} 2019 \mathrm{~S}}$ mutant is again difficult to degrade and inhibits CMA, which underlies the toxicity in PD by compromising the CMA-mediated degradation of SNCA $[197,198]$. Besides, LRRK2 ${ }^{\text {R1441G }}$, which leads to age-dependent SNCA accumulation, also inhibits CMA [198]. LRRK2 regulates macroautophagy as well, but the role remains undetermined. Many studies, involving LRRK2 kinase inhibitor and LRRK2 ${ }^{\mathrm{G} 2019 S}$, which has higher kinase activity, demonstrate that LRRK2 inhibits autophagy [199,200]. In contrast, some studies indicate that LRRK2 may promote autophagy through the activation of the MAP2K/MEK-MAPK/JNK-MAPK/ERK pathway [201] and it is reported that age-dependent dopaminergic neurodegeneration and autophagy impairment occur in lrrk1 lrrk2 double-knockout mice [202]. Further studies should integrate these relevant findings and draw a more complete model of how LRRK2 affects autophagy, which will be of great significance in designing autophagy-targeting PD therapy.

Mitochondria dysfunction has long been recognized as the initiating factor in dopaminergic neuronal loss [203]. Of note, mutations in PINK1 and PRKN, two critical proteins in mitophagy, are highly associated with PD [204]. Interestingly, PD-associated PINK1 mutations are clustered in the kinase domain [204] and several mutations such as G309D, L347P and W437X have a compromised interaction with PRKN, thus inhibiting mitophagy execution [205]. In addition to the mutations in these two proteins, studies focused on other PD-associated proteins also shed light on the importance of mitophagy in PD. Pathogenic SNCA impairs mitochondrial function via binding to OMM proteins such as TOMM20, which impairs protein import to mitochondria [206-208], or decreasing the mitochondrial SIRT3 level [209]. As mentioned above, mitophagy is responsible for impaired mitochondria degradation and a study expressing SNCA in yeast shows that Sir2-mediated 
mitophagy is induced and the selective degradation of mitochondria is responsible for the SNCA toxicity [210]. However, in neurons or in in vivo models, how SNCA-mediated mitochondrial damage is related to or affects mitophagy is unknown. Compared with SNCA, there are more studies about LRRK2 and mitophagy. It is found that the PD-associated LRRK2 ${ }^{\text {G2019S }}$ mutation inhibits mitophagy by affecting mitochondria motility [211], inhibiting mitochondrial fission [212], and phosphorylating RAB10 to inhibit its mitochondrial accumulation and interaction with OPTN [213].

Here, we focus on SNCA, LRRK2, PINK1 and PRKN, summarizing how they interact with autophagy. Other proteins with PD-associated mutations, such as VPS35, VPS13C and FBXO7, have been suggested to play a role in autophagy (Table 1).

Table 1. PD-associated genes from GWAS and their connection with autophagy (except SNCA, LRKK2, PINK1 and PRKN).

\begin{tabular}{|c|c|c|}
\hline Gene Name & Description & Reference \\
\hline GBA & $\begin{array}{l}\text { Loss of GBA function impairs autophagy via PPP2/PP2A inactivation. } \\
\text { PD-associated mutation L444P heterozygote impairs autophagy, } \\
\text { mitochondria priming and autophagy-lysosome degradation. }\end{array}$ & {$[214,215]$} \\
\hline VPS13C & $\begin{array}{c}\text { Deletion of VPS13C is correlated with impaired mitochondrial } \\
\text { morphology and upregulate PINK1-PRKN-dependent mitophagy, but } \\
\text { the study does not show the connection between PD-associated } \\
\text { mutations with mitophagy. }\end{array}$ & [216] \\
\hline \multirow[t]{3}{*}{ VPS35 } & $\begin{array}{l}\text { VPS35 } 2 \text { D620N } \text { causes autosomal-dominant Parkinson disease. } \\
\text { VPS35 } 2620 \mathrm{~N} \text { has a reduced affinity for WASH and impairs ATG9A } \\
\text { trafficking and localization, thus compromising autophagosome } \\
\text { formation. }\end{array}$ & [217] \\
\hline & $\begin{array}{c}\text { VPS35 }^{\mathrm{D} 620 \mathrm{~N}} \text { impairs endosome-to-Golgi retrieval of LAMP2A and } \\
\text { accelerates LAMP2A degradation, thus inhibiting SNCA degradation } \\
\text { through CMA. }\end{array}$ & [218] \\
\hline & $\begin{array}{l}\text { VPS35 }{ }^{\text {D620N }} \text { hampers PINK1 and PRKN recruitment to mitochondria thus } \\
\text { impairing mitophagy. }\end{array}$ & [219] \\
\hline \multirow{3}{*}{ PARK7 } & $\begin{array}{c}\text { PARK7 knockdown impairs autophagy and the SNCA uptake and } \\
\text { degradation in microglia. }\end{array}$ & [220] \\
\hline & $\begin{array}{l}\text { PARK7 deficiency downregulates HSPA8 expression level and accelerates } \\
\text { the degradation of LAMP2A, inhibiting SNCA degradation through } \\
\text { CMA. }\end{array}$ & [221] \\
\hline & $\begin{array}{l}\text { Park7 may function in mitophagy because it is important for proper } \\
\text { mitochondria function and Park7 upregulation can rescue the phenotype } \\
\text { in pink1 mutant Drosophila. }\end{array}$ & [222] \\
\hline SREBF1 & $\begin{array}{l}\text { SREBF1 knockdown inhibits PRKN translocation to mitochondria, thus } \\
\text { inhibiting mitophagy. }\end{array}$ & [223] \\
\hline \multirow{4}{*}{ FBXO7 } & $\begin{array}{l}\text { FBXO7 }^{\mathrm{T} 22 \mathrm{M}} \text { inhibits its interaction with PRKN and impairs PRKN } \\
\text { translocation to mitochondria. }\end{array}$ & \multirow{3}{*}{ [224] } \\
\hline & FBXO7 ${ }^{\mathrm{R} 378 \mathrm{G}}$ mutation impairs ubiquitination of MFN1. & \\
\hline & $\mathrm{FBXO}^{\mathrm{R} 498 \mathrm{X}}$ truncation inhibits PRKN recruitment to mitochondria. & \\
\hline & $\begin{array}{l}\text { T22M, R378G and R498X mutations aggravate aggregation of FBXO7 in } \\
\text { mitochondria, which may inhibit mitophagy. }\end{array}$ & [225] \\
\hline \multirow[t]{2}{*}{ TMEM175 } & $\begin{array}{l}\text { TMEM175 deficiency leads to the impaired autophagosome degradation } \\
\text { in the lysosome. }\end{array}$ & [226] \\
\hline & $\begin{array}{c}\text { TMEM175 }^{\mathrm{M} 393 \mathrm{~T}} \text { shows similar autophagosome clearance phenotype as a } \\
\text { knockout. }\end{array}$ & [227] \\
\hline
\end{tabular}

GWAS provides us with invaluable information to study the connection between PD and autophagy and identify therapeutic targets. However, with 90 variants nominated as PD-related factors [176], how to study them, particularly how they are related to autophagy, needs further consideration. First, some PD-associated genes are only studied by knockout instead of using the PD-associated mutated form (such as VPS13C [216]). Even though studies of mutant proteins may lead to the concern that the point mutation may not be sufficient to result in either an autophagy or pathological phenotype, further studies focusing on the mutation may shed light on a more detailed mechanism of PD and autophagy. Second, some PD-associated genes discovered through GWAS studies may affect autophagy, but few studies delve into them with regard to mechanism. For instance, 
several genes, such as CHCHD2 [228] and ATP13A2 [229,230], are critical for mitochondrial quality, but whether they have any connection with mitophagy remains unclear. Third, controversial data exist, which may have resulted from the use of different cells lines, and the phenotype at the cellular level is sometimes different from that at the behavioral level [231]. Therefore, based on the goal of specific studies, the model used to study these genes and what marker(s)/phenotype(s) should be used as an indication of PD need consideration as well.

\subsection{Alzheimer Disease}

Alzheimer disease (AD) is a progressive neurodegenerative disease characterized by cognitive impairment and loss of memory. AD patients usually show the accumulation of misfolded proteins such as amyloid- $\beta(\mathrm{A} \beta)$ and hyperphosphorylated MAPT (microtubule associated protein tau) [232].

Several lines of evidence indicate deficient autophagy in AD patients, which include the decreased level of autophagy-related genes, including BECN1 [233], ATG5 and $L C 3 B$ [234], and the accumulation of autophagosomes [235]. More importantly, the accumulation of autophagosomes correlates with AD pathology [236], which further indicates the importance of understanding the connections between autophagy and AD. Besides these direct lines of evidence, AD-associated mutation in PSEN1 disrupt autophagy [237,238]. A decreasing level of PICALM, which occurs in AD, inhibits autophagy and exacerbates AD pathology [239-241]. However, some studies report an increase in autophagy when cells are treated with $\mathrm{A} \beta$ [242]. This discrepancy could at least in part be a consequence of the AD stage. In 2016, Bordi et al. carried out a comprehensive analysis at different stages of AD, finding an upregulation of autophagy-related genes at the early stage, but an impeded autophagy flux at the late stage [243]. The mechanism of this change is not clear, possibly because autophagy is induced at the early stage to degrade the protein aggregates. However, at the later stage, autophagy or lysosome clearance ability becomes inhibited by the accumulation of abnormal proteins.

The relationship between $A \beta$ and autophagy is complicated. First, $A \beta$ is degraded through autophagy, and several studies show a decreased $A \beta$ level in cells and improved cognitive ability in an AD mouse model when autophagy is induced [244-247]. Second, A $\beta$ may also be generated inside autophagosomes because both APP (amyloid beta precursor protein) and PSEN1, an enzyme involved in the cleavage of APP to form A $\beta$, are found within the autophagosome [235]. Third, one study reported that the secretion of $A \beta$ to the extracellular space, where plaque forms, depends on autophagy in neurons [248]. On the contrary, a recent study indicates that MTORC1 inhibition reduces amyloid secretion due to the upregulation of autophagy [249]. Interestingly, the activation of AMPK does not induce autophagy in neurons, and different AMPK activators results in differential regulation of $A \beta$ secretion, either increasing or reducing, which indicates a complex role of AMPK in $A \beta$ secretion independent from autophagy [249].

APP has a KFERQ motif, which is typically associated with CMA. However, the deletion of this motif in APP does not abolish its interaction with HSPA8, but conversely, increases the interaction [250]. The authors raise the possibility that the KFERQ motif may be used to bind to AP2, which is an autophagy adaptor, because the AP2 recognition sequence is part of KFERQ; deletion of the KFERQ motif impairs AP2-dependent targeting to the lysosome. Further studies should investigate the binding partner of the KFERQ motif other than HSPA8; this may lead to the identification of new functions of this motif other than acting as the CMA signal and shed more light on AD pathology.

The other hallmark protein in AD, MAPT, is a substrate of macroautophagy, CMA and microautophagy, but some AD-associated MAPT mutations cannot be cleared efficiently by autophagy [251,252]. Consistently, activation of autophagy through inhibiting MTORC1 helps with prolonged clearance of MAPT [253]. CMA is downregulated in AD patient brains [254]; CMA upregulation improves the disease phenotype that results from MAPT or 
combined MAPT and A $\beta$ pathologies, and inhibition of CMA accelerates the AD pathology in a mouse model [254].

Together with $\mathrm{A} \beta$ and MAPT, compromised mitochondria accumulation is another hallmark of AD. Although it is unclear whether the mitochondrial dysfunction is a cause or a consequence of $\mathrm{A} \beta$ and phosphorylated MAPT accumulation [255], it indicates that quality control of mitochondria is impaired in AD neurons. Deficient mitophagy has been discovered in AD patient brain and patient stem-cell derived neurons [256]. The compromised mitophagy in AD may resulted from the following. First, in AD patient brains, PINK1-PRKN-dependent mitophagy is enhanced with $A \beta$ accumulation, but it is followed by a progressively depleted PRKN $[257,258]$, suggesting that mitophagy is induced at the early stage of $\mathrm{AD}$, but finally shows an inadequate capacity compared with the huge number of damaged mitochondria. Additionally, higher levels of $\Delta 1$ PINK1, the main cleaved product of PINK1, is found in AD patient brain, which inhibits PRKN translocation to mitochondria and impairs mitophagy [258]. Second, emerging data are showing that $\mathrm{A} \beta$ and phosphorylated MAPT interfere in the mitophagy pathway and MAPT impairs PRKN translocation to mitochondria [259-261]. Overall, these studies demonstrate that compromised mitophagy and abnormal mitochondrial dynamics contribute to $\mathrm{AD}$ pathogenesis.

\subsection{Huntington Disease}

Huntington disease (HD) is characterized by cognitive dysfunction, uncontrolled movement, and alternation in mood [262]. HD is caused by the accumulation of a mutant (m) form of HTT (huntingtin), which has abnormally long tracts of polyglutamine (polyQ) repeats [262].

mHTT aggregates can be degraded through selective autophagy, with the help of SQSTM1 [263] and OPTN [264] as the receptors, indicating autophagy is critical to prevent HD. Interestingly, a study shows that the depletion of SQSTM1 leads to a longer life span in a mouse model with mHTT [265]. The data suggest that the aggerated MHTT is localized in both the nucleus and cytoplasm. SQSTM1 deletion only affects the protein degradation in the cytosol but not the nucleus, and the reduced nuclear inclusion may result from the inhibited nuclear transport of mHTT from the cytosol [265]. However, in this study, the inhibition of autophagy through ATG5 knockout is toxic, still indicating the importance of autophagy in protein aggregate clearance and inhibiting HD pathology [265].

Autophagy activity is altered in HD. It has been reported that autophagy-associated gene expression is changed in HD patients [266]. Even though some genes at the early autophagy stages are upregulated [266], autophagy activity is impaired because of the deficient capability of trapping cytosolic cargos [267]. Additionally, mHTT leads to decreased phosphorylation of ATG14 by ULK1, which further leads to the reduction in PtdIns3K kinase activity and autophagy [268]. Therefore, not surprisingly, inducing autophagy either through the MTORC1-dependent pathway or MTORC1-independent pathway can reduce the toxicity of mHTT and ameliorate the HD phenotype [269-271].

Of note, conformational polymorphism of polyQ proteins has been suggested [272] and the polyQ antibody 3B5H10-recognized mHTT is the most toxic form; it has a slower degradation rate because of the resistance to K63 ubiquitination and SQSTM1 recognition [273]. It also raises some questions to consider. For example, is there a conversion between different conformations? Can we convert the ones that are the most resistant to degradation to more autophagy sensitive forms? The answers to these questions may lead us to think about new ways to ameliorate mHTT accumulation to treat HD.

Even though mutant HTT leads to protein aggregates and neurotoxicity, wild-type HTT, in contrast, helps autophagy. The role of HTT as a scaffold protein in selective autophagy is suggested by a similar structure between the C-terminal domain of HTT and yeast Atg11 and the capability of binding with key Atg11 interactors [274]. Further study confirms the interaction between HTT and SQSTM1 to facilitate its connection between LC3 and ubiquitinated cargo [275]. Additionally, this study also shows that HTT binds to ULK1, 
releasing it from the negative regulation by MTORC1, to reach the maximal activation of selective autophagy, and this modulation only occurs when selective autophagy is specifically induced but not during starvation-induced autophagy [275]. This elegant study reveals a positive role of HTT in selective autophagy, but also raises several questions. How is HTT regulated to distinguish between selective autophagy and starvation-induced autophagy? To what extent does the HD-associated mutation affect normal HTT function? The answers to these questions will bring us a better understanding about the relationship between HTT and autophagy and may shed light on new autophagy-based therapeutic approaches to HD.

\subsection{Autophagy and Therapy of Neurodegenerative Diseases}

As mentioned above, autophagy can degrade toxic protein aggregates, which are the major causes of neurodegenerative diseases, raising the possibility that modulation of autophagy could be a possible therapeutic approach to the treatment of such diseases. Potential autophagy-targeting therapeutic approaches can be divided into three categories. First, generally stimulating autophagy may help in the clearance of aberrant protein aggregates and improve the symptoms of the pathology. Multiple autophagy-inducing small molecules have been tested in the mouse model [276]. For instance, rapamycin and its analog temsirolimus lower the level of MAPT [277] and rescue memory impairment in an AD mouse model [278]. In addition, rapamycin is also able to improve the motor ability of both PD and HD mice $[269,279]$ and to revert the cognitive and affective deficits of PD mice [280]. Trehalose, an AMPK activator, not only induces autophagy and improves the clearance of SNCA and motor function in PD mice injected with SNCA ${ }^{\mathrm{A} 53 \mathrm{~T}}$ [281] but improves HD pathology as well [282]. Furthermore, applying the combination of rapamycin and trehalose to the PD mouse model shows an additive effect on dopaminergic deficits [283]. In addition, felodipine, a calcium channel blocker and autophagy inducer, can stimulate the degradation of SNCA in PD mice and improve the motor ability of HD mice [284]. S14G-humanin and melatonin can alleviate the accumulation of $A \beta$ in the brain [285] and prevent cognitive decline [286] through inducing autophagy in AD mice. Besides the chemicals tested in the mouse model, lithium and metformin are being used in clinical trial in patients with mild cognitive impairment, which is associated with high risk of PD, and the studies indicate that these two autophagy-stimulating molecules can attenuate cognitive decline in these patients $[287,288]$. Nilotinib, an AMPK activator, has also been used in a clinical trial of PD patients [289].

Second, mitophagy dysregulation is also highly associated with neurodegenerative diseases; therefore, molecules modulating mitophagy may improve neurodegenerative pathologies. This idea has been tested in an AD mouse model. Treating the AD mice with urolithin A, a mitophagy inducer, inhibits MAPT hyperphosphorylation and improves memory [256]. Recently, through a screening of more than 2000 FDA-approved drugs or drug candidates, Cen et al. found UMI-77 as a mitophagy inducer and treating the APP/PS1 mouse model with UMI-77 reduces the brain insoluble A $\beta$ level [290].

Third, specifically attaching neurodegeneration-associated proteins to LC3 or HSPA8 can induce their degradation through autophagy or CMA, respectively. In 2010, a 46 amino-acid peptide adaptor molecule was designed, which contains an expanded polyQ tract-binding motif and two HSPA8-binding motifs. This molecule is sufficient to reduce polyQ aggregation, ameliorate symptoms and extend the life span of HD mice [291]. Recently, adapting the idea of autophagic degradation of $\mathrm{mHTT}$, researchers found small molecules that interact with mHTT and LC3 at the same time, which are sufficient to bring mHTT to the phagophore, reduce the MHTT level and alleviate the HD-related phenotype [292]. Similarly, a cell membrane-penetrating peptide, which specifically binds the $A \beta$ oligomer and contains three CMA-targeting motifs can reduce the $A \beta$ oligomer level and protect neurons from $A \beta$ oligomer-induced neurotoxicity [293]. However, this peptide has only been tested in neurons, and not in an AD mouse model. Therefore, further experiments are needed to demonstrate its practicality in vivo. 
Even though the studies mentioned above indicate intriguing results of autophagytargeting therapy, the complicated connection between autophagy and neurodegenerative diseases requires us to get an even deeper understanding before we could apply these approaches efficiently. The complexity of this relationship first come from the various disease-associated mutations that may affect different steps of autophagy. If the mutant protein inhibits the later steps of autophagy, such as the degradation step, then inducing autophagy from the early steps may not improve the degradation of protein aggregates and on the contrary may bring side effects because of the increasing accumulation of autophagosomes. Another reason of the complexity is that autophagy not only can degrade proteins aggregates, but also affect their secretion, especially for $\mathrm{A} \beta$ in $\mathrm{AD}$ as mentioned above. Even though the role of autophagy in $A \beta$ secretion is undetermined, it is worth further study because if autophagy is required for $A \beta$ secretion, promoting autophagy as a treatment of $\mathrm{AD}$ may be at the expense of higher extracellular $\mathrm{A} \beta$ and plaque formation. Of note, inducing autophagy after plaque formation has no effect on AD-like pathology and cognitive deficits [294], which also indicates that the disease stage to apply autophagytargeting therapy is critical. Additionally, because autophagosomes are a site where $A \beta$ is generated [235], whether stimulating autophagy will induce the generation of $A \beta$ and if so, whether the upregulated clearance of $A \beta$ can offset the increase in production should be assessed. Because of the complexity, personalized analysis about the cause of the disease and the disease stage may be needed.

How to evaluate the efficiency of an autophagy-targeting approach also needs serious consideration. One recent study pointed out that impaired autophagy in dopamine neurons in a mouse PD model expressing human SNCA improves motor performance even though the pathology of PD such as progressive neuron loss still exists [231], indicating that while upregulating autophagy is beneficial for cellular pathology, it may lead to an opposite consequence on organismal behavior. Therefore, clinicians and researchers also need to carefully consider whether it is better to examine the cellular or the behavioral level for signs of improved pathology.

\section{Autophagy and Infectious Diseases}

\subsection{Autophagy and Bacterial Infection}

As mentioned previously, autophagy can be selective, and the invading pathogens can be substrates of autophagy. This selective autophagy is named xenophagy [295]. In this context, autophagy functions as an innate immune mechanism to fight against infectious bacteria. Not surprisingly, bacteria have developed strategies to escape from the autophagic degradation. Here, we will briefly discuss the interaction between autophagy and infectious bacteria (Figure 3).

Salmonella enterica serovar Typhimurium (S. Typhimurium) is one of the most common model bacteria used to study xenophagy. Salmonella invades cells and resides within the cytosol in a modified phagosome termed a Salmonella-containing vacuole (SCV). When the SCV membrane is damaged and the bacterium is exposed to the cytosol, it will be ubiquitinated; this results in the recruitment of several ubiquitin-binding autophagic receptors, such as SQSTM1, OPTN and CALCOCO2/NDP52, which will target the bacterium to the phagophore. The bacterium will finally get trapped in the autophagosome, which fuses with a lysosome for degradation [296]. Additionally, the damaged SCV can be sensed by the vacuolar-type $\mathrm{H}^{+}$-ATPase, which then recruits ATG16L1 for autophagosome formation [297]. Damage to the SCV also exposes $\beta$-galactoside, which is usually localized on the lumenal surface of endosomes, to the cytosol. $\beta$-galactoside can be recognized by LGALS8 (galectin 8), which will then recruit autophagy receptor CALCOCO2 [298]. Similarly, Mycobacterium tuberculosis (M. tuberculosis) enters the cell through phagosomes. Permeabilization of the phagosome allows the ubiquitination of the bacterium and the subsequent recognition by autophagy receptors such as SQSTM1 and CALCOCO2 [299]. In addition, ubiquitin binds directly to the ubiquitin-associated domain on the bacterial surface protein Rv1468c independently from the E3 ligase and recruits autophagy recep- 
tors [300]. Autophagy also selectively targets cytosolic bacteria, such as Streptococcus pneumoniae (group A streptococcus). After escaping from endosomes to the cytosol, most of the group A streptococcus will be sequestered within LC3-decorated autophagosome-like vesicles and degraded through fusion with a lysosome [301]. Several RAB GTPases are involved in this process, including RAB7, RAB9A and RAB23, which are responsible for the formation of the vesicles and fusion with lysosomes [302,303]. Interestingly, RAB23 and RAB9A do not participate in starvation-induced autophagosome formation [303]. Additionally, a recent study indicates that the outer-membrane vesicles from Gram-negative bacteria induce xenophagy even before entering the cells through activating AMPK, but non-selective autophagy is not induced [304]. Together, these studies demonstrate a special regulating mechanism of xenophagy but not non-selective autophagy.

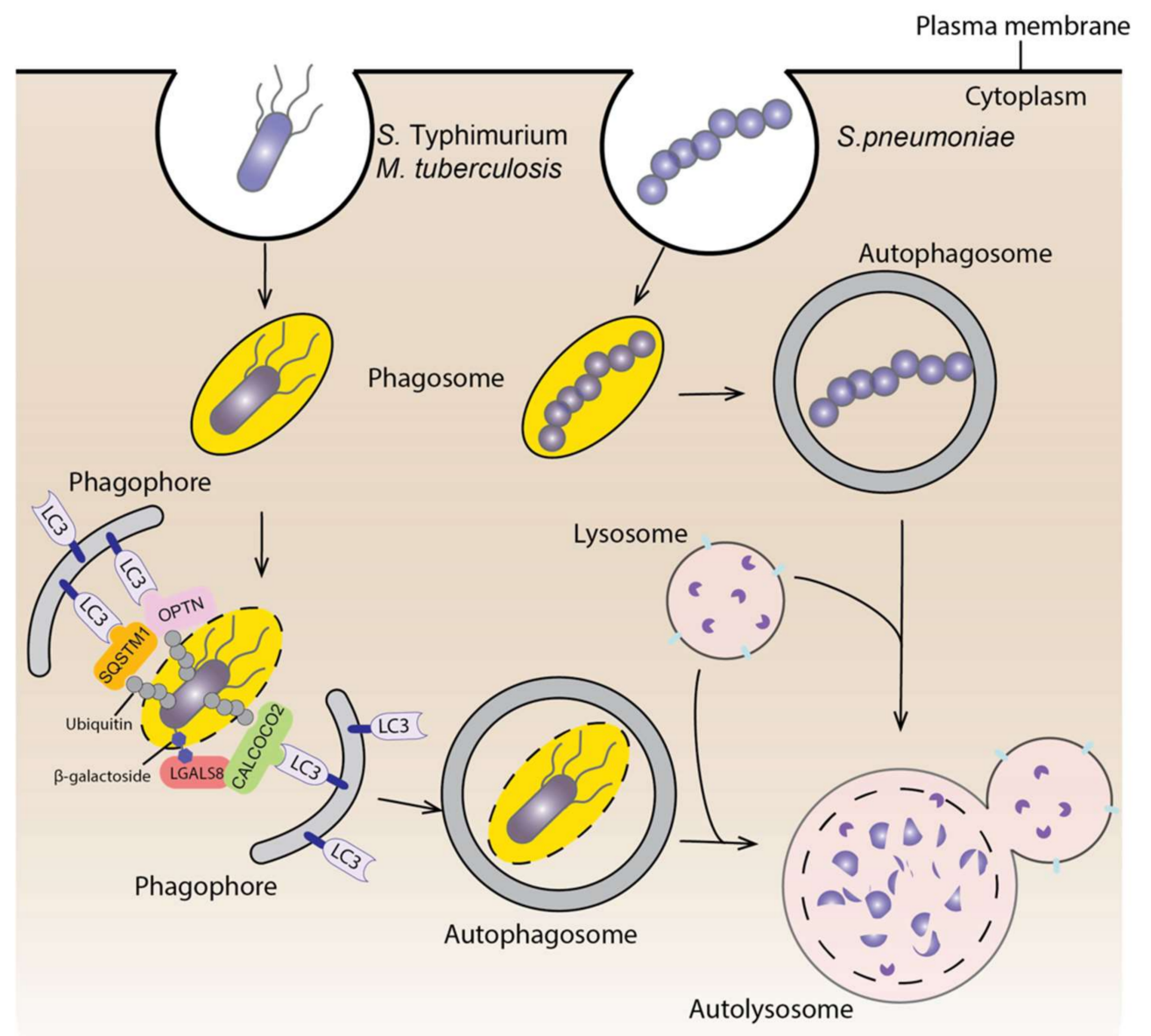

Figure 3. Autophagy and bacterial infection. Bacteria enter the cell within a phagosome or vacuole. Autophagy can target the bacteria within a damaged vacuole or phagosome (such as $S$. Typhimurium and M. tuberculosis). The ubiquitination of the bacterium and the recognition of $\beta$ galactoside by LGALS8 will recruit autophagy receptors to target the bacterium in to the phagophore. Autophagy can also target cytosolic bacteria (such as S. pneumoniae) causing them to be trapped within an autophagosome. Subsequently, the autophagosome will fuse with a lysosome to degrade invading bacteria.

Because of the potential degradation through autophagy, many bacteria have evolved mechanisms to hijack this process to allow their survival and replication within infected cells. First, bacteria can inhibit autophagy initiation signaling. For instance, S. Typhimurium infection induces lysosomal degradation of AMPK and reactivation of MTORC1, thus inhibiting autophagy [305]. Second, some bacterial proteins can directly interact with autophagy-associated proteins and inhibit their functions. RavZ, a Legionella pneumophila 
effector protein, hydrolyzes the bond between the glycine and the aromatic residue of LC3, thus producing non-functional LC3 that cannot be reconjugated with PE [306]. VirA, a Shigella flexneri effector protein, interacts with RAB1 and inhibits its function, thus prohibiting phagophore biogenesis around the bacteria [307,308]. RAB1 is also bound by SseF and SseG secreted by $S$. Typhimurium, which inhibits ULK1 activation and PtdIns3P biogenesis, thus impairing autophagy and supporting the survival and replication of the bacteria [309]. Additionally, in S. Typhimurium SopF, a type III secretion system effector, inhibits the recruitment of ATG16L1 to the SCV by the vacuolar-type $\mathrm{H}^{+}$-ATPase upon vacuole damage, thus impairing autophagy initiation [297]. Third, several types of bacteria block autophagosome and lysosome fusion, including M. tuberculosiss [310], and Helicobacter pylori [311]. Besides the three mechanisms mentioned above, bacteria can escape autophagy through masking their surface and through some unknown mechanisms [312]. To summarize, xenophagy is an efficient way to clear bacteria that have invaded into cells and the research focusing on how bacteria escape from autophagy will guide us to design autophagy-targeting approaches to treat infectious diseases.

\subsection{Autophagy and Viral Infection}

Viruses are also the target of selective autophagy [313] and the specific degradation of viruses through autophagy is named virophagy. Several viruses have been demonstrated as the cargo of virophagy, but they can be targeted to this pathway via different mechanisms. For example, LGALS8 detects $\beta$-galactosides when picornaviruses are released from endosomes, marking them for autophagic degradation [314]. In addition, hepatitis $C$ virus NS5A (nonstructural 5A) protein, which is critical for HCV RNA replication, interacts with SHISA5/SCOTIN and gets targeted to phagophores, leading to degradation via autophagy [315].

Autophagy also supports virus survival in host cells [316]. Autophagy is needed by some common viruses for their infection and normal replication, including polioviruses [317], hepatitis C virus [318,319], and influenza A virus [320]. The studies summarized above indicate the dual role of autophagy in viral infection, suggesting that targeting autophagy could be a promising way to deal with viral infection.

\subsection{Autophagy and COVID-19}

Among a wide range of human viruses, the one that has recently received the most attention is the severe acute respiratory syndrome coronavirus 2 (SARS-CoV-2), a betacoronavirus resulting in the ongoing coronavirus disease 2019 (COVID-19) pandemic, which is having a dramatic impact on healthcare and society worldwide. Because the interplay between other coronaviruses from the same family, including SARS-CoV and Middle East respiratory syndrome coronavirus, and autophagy is shown by many previous studies [321-324], the involvement of autophagy in SARS-CoV-2 infection has been suggested and drugs targeting autophagy have been proposed for COVID-19 treatment $[325,326]$. This year, many studies have focused on this field, revealing a close but complex connection between SARS-CoV-2 infection and autophagy.

Several large-scale studies, including the use of transcriptomics and proteomics analysis, suggest that SARS-CoV-2 proteins perturb the host cell autophagic pathway $[327,328]$. More specifically, a systematic functional analysis of SARS-CoV-2 proteins found that ORF3a and ORF7a disturb autophagy flux via different mechanism: ORF3a inhibits the fusion between autophagosomes and lysosomes, whereas ORF7a inhibits lysosome acidification [329]. How ORF3a inhibits fusion is illustrated by two independent studies, which indicate that SARS-CoV-2 ORF3a interacts with VPS39, inhibiting the interaction between the homotypic fusion and protein sorting/HOPS complex and RAB7 or STX17, consequently preventing the formation of a STX17-SNAP29-VAMP8 SNARE complex, and therefore impairing autophagosome-lysosome fusion [330,331]. Another study indicates that ORF3a interacts with UVRAG, thus positively regulating PtdIns3K complex I but inhibiting the formation of complex II. As a result, autophagosome formation can be in- 
duced, but maturation is compromised [332]. Why does SARS-CoV-2 choose to inhibit the late steps of autophagy? One possibility is that SARS-CoV-2 uses phagophores or autophagosomes for their replication. Several genetic screens aiming to identify host factors for SARS-CoV-2 suggest the importance of autophagosomes in viral replication [333-336]. In BECN1 or PIK3R4 knockout cells, the replication of SARS-CoV-2 is almost blocked [333]. Additionally, inhibiting the PtdIns3K complex results in a striking decrease in viral load, with some inhibitors reaching a more than 100-fold reduction [334,337]. Interestingly, TMEM41B, an ER-localized protein, is critical not only for the infection of SARS-CoV-2, but other seasonal coronaviruses as well $[335,336,338]$. TMEM41B has been indicated to participate in autophagy: deletion of TMEM $41 B$ leads to a stall during autophagosome biogenesis [339-341], suggesting that the reason TMEM41B deletion inhibits SARS-CoV-2 may be due to the compromised autophagosome formation. Furthermore, double-membrane vesicles are a major coronavirus replication organelle [342,343]; therefore, autophagosomes or phagophores, which are double membrane, are likely to be involved in this process. Additionally, ACE2 (angiotensin converting enzyme 2), the first reported receptor for SARS$\mathrm{CoV}-2$, contains a LIR motif in its cytoplasmic region, which potentially recruits autophagy elements such as LC3 to facilitate the incoming coronavirus replication [344]. However, on the contrary, some studies report that CQ or HCQ treatment inhibits SARS-CoV-2 infection $[337,345,346]$. Therefore, whether autophagy facilitates and whether phagophores and/or autophagosomes are sites for SARS-CoV-2 replication need further investigation.

Autophagy may help SARS-CoV-2 escape from the host immune response. One recent study determined that overexpressing one of the SARS-CoV-2 main structural proteins, $\mathrm{M}$, induces mitochondria degradation through mitophagy to block innate immunity signaling and inhibit the type I IFN (interferon) response [347]. Additionally, ORF8 of SARS-CoV2 mediates the degradation of major histocompability complex class I (MHC-I) through autophagy [348], while the specific mechanism and the receptor for this selective autophagic degradation remain unknown.

Another unanswered question is whether SARS-CoV-2 can be degraded through autophagy. It is possible that SARS-CoV-2 inhibits autophagy to protect the virus from degradation. Besides inhibiting autophagy in the fusion step mentioned above, coronaviruses may use the lysosome for non-lytic viral release, which involves lysosomal deacidification and compromised lysosomal hydrolase activity [349]. A recent study points out that SARS-CoV-2 infection results in the accumulation of key metabolites, the activation of autophagy inhibitors and the reduction of several ATG proteins involved in different steps of autophagy including the initiation step [350]. In addition, autophagy induction restricts SARS-CoV-2 growth in primary human lung cells [350], which is consistent with another finding that rapamycin treatment reduces viral replication 4-6 fold [329]. Even though the result of inducing autophagy is not as striking as inhibiting autophagy, as mentioned above, it still suggests the potential role of autophagy in viral degradation.

Despite the studies mentioned above, we must continue to explore the potential dual roles of autophagy in SARS-CoV-2 infection. Having a clearer understanding of the relationship between SARS-CoV-2 and autophagy will help us optimize an autophagytargeting therapeutic strategy to treat COVID-19.

\section{Autophagy and Metabolic Disorders}

Autophagy, as mentioned above, is a critical process for energy replenishment when the cell is in a stressful environment and is important to maintain the balance of metabolites. In line with this, dysregulation of autophagy has been seen in, and been proposed as one of the causes of, metabolic disorders. Similar to other diseases, the role of autophagy in metabolic disorders is complicated. In this section, we briefly summarize the studies revealing the relationship between autophagy and metabolic disorders, focusing on obesity and diabetes mellitus.

Obesity is one of the most common metabolic disorders around the world and is characterized by the accumulation of dysfunctional adipose tissue when the energy intake 
exceeds the energy expenditure [351]. Autophagy alternation has been found in many different tissues in obese individuals or in a mouse obesity model. For instance, both genetic or dietary obesity leads to the downregulation of autophagic proteins in liver such as ATG7 [352], and high-fat diet reduces hepatic ATG12, ATG5 and LC3-II levels [353]. In adipose tissue, most studies report an increased autophagy in obese patients $[354,355]$, but high-fructose-induced obesity results in a decreased expression of ATG genes [356]. Controversial results are also seen in pancreas and heart [351]. The discrepancy among studies may result from different modes of obesity induction: amino acids, glucose and lipids have different metabolic pathways and may regulate autophagy through alternate pathways [351].

Autophagy is not only changed in an obesity model; dysregulation of autophagy is also suggested as one of the causes of obesity and concomitant metabolic disorders such as insulin resistance (Table 2). Autophagy may be related to obesity from two aspects. First, autophagy is critical in adipogenesis. Multiple ATG genes are actively regulated during the adipocyte differentiation [357] and several studies indicate that blockage of autophagy by knocking out essential ATG genes impairs adipogenesis [358,359]. Furthermore, some autophagy-regulating proteins or chemicals are reported to modify adipogenesis. For instance, CEBPB /C /EBP $\beta$ facilitates adipogenesis via activating ATG4B and promoting autophagy [360]. $\beta$-Cypermethrin promotes adipogenesis through inducing autophagy and shaping a microenvironment that is suitable for adipogenesis [361]. However, autophagy is critical and most active only during the initial stage of adipocyte differentiation but not in the later stage [362]. Recently, a study reported decreased RUBCN expression and subsequent upregulated autophagy in aged adipose tissue, which worsens the age-related metabolic disorder [363], indicating that even though autophagy is necessary for adipogenesis, excessive autophagy may not be beneficial for adipose tissue especially during the later stage. Second, autophagy is critical for maintaining the balance between white adipose tissue (WAT), which stores energy, and brown adipose tissue (BAT), which is responsible for thermogenesis [364]. Autophagy facilities brown or beige adipocyte whitening, possibly through the degradation of mitochondria $[365,366]$. This idea is supported by other studies showing that deficient PRKN helps beige adipocyte maintenance [367], and PRKNmediated mitophagy is downregulated during the browning of white adipocytes [368]. Additionally, thermogenic activation suppresses autophagy in brown adipocytes, which may help brown adipocyte maintenance and thermogenesis [369]. Therefore, inhibiting autophagy in BAT may become a way to prevent obesity by impairing the conversion from BAT to WAT [370]. 
Table 2. In vivo studies of the altered autophagy effect on metabolic phenotype.

\begin{tabular}{|c|c|c|c|c|c|}
\hline Genotype & Target Organ & Modulation on Autophagy & Model & Phenotype & Reference \\
\hline $\operatorname{Atg} 7^{+/-}$ & Whole body & Suppression & Cross with ob/ob mice & $\begin{array}{l}\text { Resistance to insulin. } \\
\text { Increased intracellular lipid } \\
\text { content. }\end{array}$ & {$[371]$} \\
\hline $\operatorname{sh} 3 g l b 1^{-/-}$ & Whole body & Suppression & HFD or NCD & $\begin{array}{l}\text { Higher body weight under both } \\
\text { diets. } \\
\text { Insulin resistance under HFD. }\end{array}$ & [372] \\
\hline $\operatorname{Becn} 2^{+/-}$ & Whole body & Suppression & HFD or NCD & $\begin{array}{l}\text { Obesity. } \\
\text { Insulin resistance. }\end{array}$ & [373] \\
\hline $\operatorname{atg} 4 b^{-1-}$ & Whole body & Suppression & Fasting, HFD or sucrose fed & $\begin{array}{l}\text { Reduced starvation-induced } \\
\text { weight loss. } \\
\text { Larger adipocytes in visceral fat } \\
\text { tissue and increased hepatic } \\
\text { steatosis. } \\
\text { Reduced glucose tolerance and } \\
\text { attenuated insulin sensitivity. }\end{array}$ & [374] \\
\hline Atg5 overex pression & Whole body & Enhancement & NCD and aging & $\begin{array}{c}\text { Lower body weight. } \\
\text { Enhanced insulin sensitivity. } \\
\text { Resistance to age-associated } \\
\text { obesity. }\end{array}$ & [375] \\
\hline Becn1 ${ }^{\text {F121A }}$ knockin & Whole body & Enhancement & HFD & $\begin{array}{l}\text { Impaired glucose tolerance but } \\
\text { improved insulin sensitivity. }\end{array}$ & [376] \\
\hline $\operatorname{atg} 7^{-1-}$ & Adipose tissue & Suppression & HFD or NCD & $\begin{array}{l}\text { Lower body weight. } \\
\text { Lower white adipose tissue mass. } \\
\text { Resistance to HFD-induced } \\
\text { obesity. } \\
\text { Enhanced insulin sensitivity. }\end{array}$ & {$[377,378]$} \\
\hline$f t o^{-/-}$ & Adipose tissue & Suppression & HFD or NCD & $\begin{array}{l}\text { Lower white fat mass. } \\
\text { Lower body weight. }\end{array}$ & [379] \\
\hline $\operatorname{atg} 3^{-/-}$ & Adipose tissue & Suppression & HFD or NCD & Induced insulin resistance. & [380] \\
\hline $\operatorname{atg} 16 l 1^{-/-}$ & Adipose tissue & Suppression & NCD & Induced insulin resistance. & [380] \\
\hline
\end{tabular}


Table 2. Cont

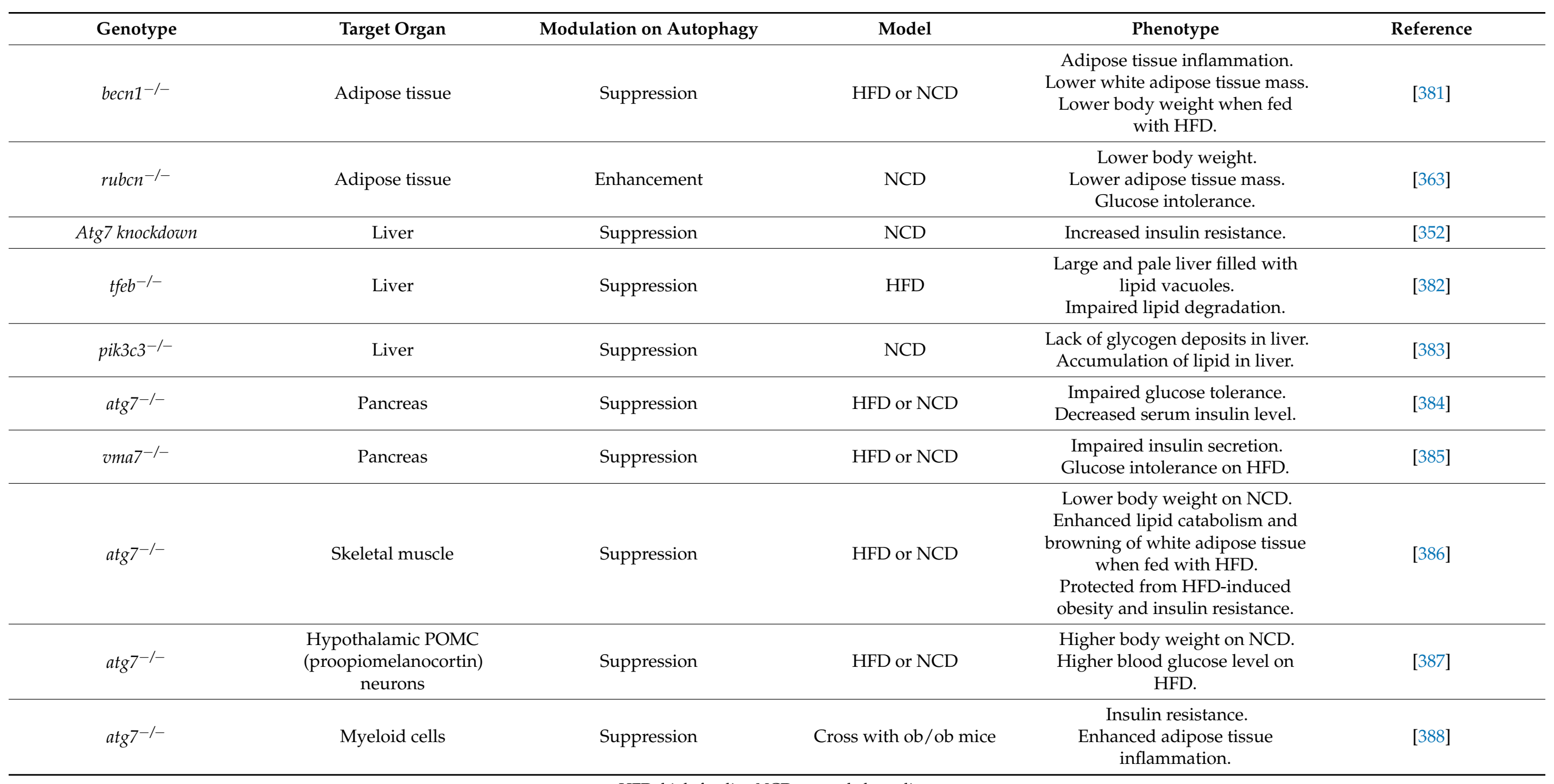

HFD, high-fat diet; NCD, normal-chow diet. 
Type 2 diabetes mellitus (T2DM) is one of the most common chronic metabolic diseases associated with obesity, which is characterized by the resistance to insulin and inability to produce insulin by pancreatic $\beta$-cells [389]. Multiple studies have shown altered $\beta$-cell autophagy in mouse obesity or diabetes models and the ablation of autophagy in $\beta$-cells leads to decreased insulin secretion and impaired glucose tolerance (Table 2) [390]. T2DM also features the accumulation of IAPP (islet amyloid polypeptide), which is toxic to $\beta$-cells through inducing apoptosis. $\beta$-cell autophagy inhibition leads to glucose intolerance and loss of $\beta$-cell mass in human IAPP-expressing mice [391,392] and inducing autophagy facilitates the clearance of IAPP and improves $\beta$-cell activities [393]. All these studies suggest the importance of autophagy in maintaining normal $\beta$-cell functions and protecting the individual from diabetes. Autophagy is beneficial to $\beta$-cells from different aspects. First, autophagy can protect $\beta$-cells from ER stress. Because $\beta$-cells have a high demand to produce and secrete proteins, they are quite susceptible to ER stress. ER stress is an inducer of autophagy, which serves a cytoprotective role in $\beta$-cells [394-396]. Second, ROS is a signal of insulin secretion due to the increasing level of glucose [397], but chronic exposure to ROS leads to abnormal mitochondria, inflammatory damage and finally cell death. Mitophagy in $\beta$-cells can serve as an adaptive response to the proinflammatory cytokines and protect $\beta$-cells from inflammatory damage [398]. Compromised mitophagy is found in patients with newly diagnosed T2DM and advanced duration T2DM [399]. The impaired mitophagy of diabetes could result not only from the decreased expression of mitophagy genes [399], but the ER-stress and oxidative-stress-induced cytosolic TP53 [400] and also the accumulation of IAPP in $\beta$-cells [401]. Moreover, PDX1, which is critical for $\beta$-cell mitophagy [402], also has a lower expression level in diabetic models [403]. The fact that mitophagy promotion via overexpressing PRKN or deficient TP53, or sonodynamic therapy can inhibit $\beta$-cells dysfunction and maintain insulin secretion in diabetic mice further indicates the importance of mitophagy in preserving the normal function of $\beta$-cells $[400,404]$. Of note, even though autophagy is important for $\beta$-cells, too much autophagy may inhibit insulin secretion by degrading insulin granule vesicles [376]. The studies summarized above focus on T2DM, but in type 1 diabetes mellitus (T1DM), $\beta$-cell autophagy is also compromised [405]. However, how this impaired autophagy is associated with T1DM needs further study.

Several autophagy-inducing molecules have been tested in a mouse obesity model and the treated mice show ameliorated obesity and associated phenotypes. For example, ADIPOQ/adiponectin stimulates autophagy and reduces insulin resistance caused by highfat diet (HFD) [406]. Injecting mangiferin, which induces autophagy, into HFD-fed mice improves glucose tolerance and lowers body weight [407]. Liraglutide, a GCG (glucagon)like peptide-1 (GLP-1) analog, relieves lipid accumulation in the liver of HFD-fed mice through inducing autophagy [408]. More recently, from a screening of small molecules that act as autophagy stimulators, researchers identified MSL, a compound that can reduce the intracellular lipid level; obese mice treated with MSL have a better metabolic profile [409]. In addition to the chemicals that stimulate autophagy, the autophagy inhibitor HCQ protects mice from HFD-induced obesity and insulin resistance [410]. A clinical study also proposed that HCQ is favorable to $\beta$-cell function and lowers the risk of T2DM [411].

Even though some drugs targeting autophagy in obesity have been designed, questions remain concerning the practicality of modulating autophagy to treat this condition. First, most of the studies are done in mouse models. However, the living environment and diet of humans is much more complicated, which may result in different consequences compared to mice. Second, autophagy in different tissues responds or contributes differently to metabolic disorders. Can a drug target one specific tissue and modulate autophagy? If not, whether the effect on other tissues can affect the efficiency of autophagy regulation needs to be determined. Third, the specific degradation of lipid droplets through autophagy, lipophagy, is also considered as an important regulator of metabolism. The role of lipophagy is mostly discussed in the context of fatty liver diseases [412], but some studies 
also show that lipophagy may be related to obesity and diabetes. For instance, a recent study designed autophagy-tethering compounds targeting lipid droplets to induce their degradation. Treating mice with these compounds leads to a lower body weight [413], which indicates a role of lipophagy in obesity. However, the mechanism and the treatment potential of modulating lipophagy need further study.

Besides drug intervention, lifestyle modifications, such as intermittent fasting (IF), are also beneficial for metabolism in the mouse models [414,415] and in humans [416]. The benefits of IF may come from its regulation of autophagy. Fasting can induce autophagy in liver and stimulate lipid degradation [417]. IF can also increase autophagy flux in islets, which enhances $\beta$-cell survival and glucose-stimulated insulin secretion [418]. Intermeal fasting is also proposed to induce autophagy and be beneficial to metabolism [419].

\section{Conclusions and Perspectives}

Because autophagy is not only important for energy replenishment during starvation, but also to maintain cellular homeostasis, this pathway has a close connection with human diseases, and the emerging roles of autophagy in disease outcome provide a potential for breakthrough in investigating the mechanism of human diseases and designing therapeutic approaches. In this review, we only summarize the role of autophagy in four types of diseases: cancer, neurodegenerative diseases, infectious diseases, and metabolic disorders, but many other human diseases such as those involving the heart, lungs, kidney, retina, muscle and autoimmunity are also related to autophagy [420] (Figure 4). Even though an increasing number of studies focus on autophagy and human diseases, there are still many questions that need further consideration.

First, using different models and genetic approaches, the modulation of autophagy gives us exciting but sometimes controversial results, indicating the dual roles of autophagy in diseases. The dual role of autophagy could result from studies examining different disease stages and may be inherent to the differences between pathological and physiological autophagy. More investigations are needed to determine what regulates the changing of roles of autophagy, which will provide us with more information when considering modulating autophagy as an approach to overcome diseases.

Second, to what extent we can modulate autophagy needs serious consideration. Even though modulating autophagy seems to be a promising strategy to treat some diseases, autophagy has its own physiological roles and too much or too little autophagy can both be harmful. Deficient autophagy may lead to acute infectious diseases and tissue aging while excessive autophagy could result in cell death. Moreover, autophagy proteins also function in autophagy-independent pathways. The modulation of these proteins may lead to the dysregulation of other pathways, which brings potential side effects. Therefore, autophagy modulators that can be more precisely targeted to disease-related tissues, and targeting more autophagy-specific proteins, should be optimal ways to treat pathologies.

Third, selective autophagy is closely related to human diseases, such as mitophagy and selective removal of protein aggregates (aggrephagy) in neurodegenerative diseases, xenophagy in infectious diseases, and lipophagy in metabolic disorders. Sometimes, selective autophagy regulation is uncoupled from non-selective autophagy. Therefore, it is possible that we can specifically target selective autophagy rather than non-selective autophagy for disease treatment to reduce the potential side effects of these manipulations. However, how this uncoupled regulation is accomplished and whether there are chemical components/metabolites involved need to be addressed. 


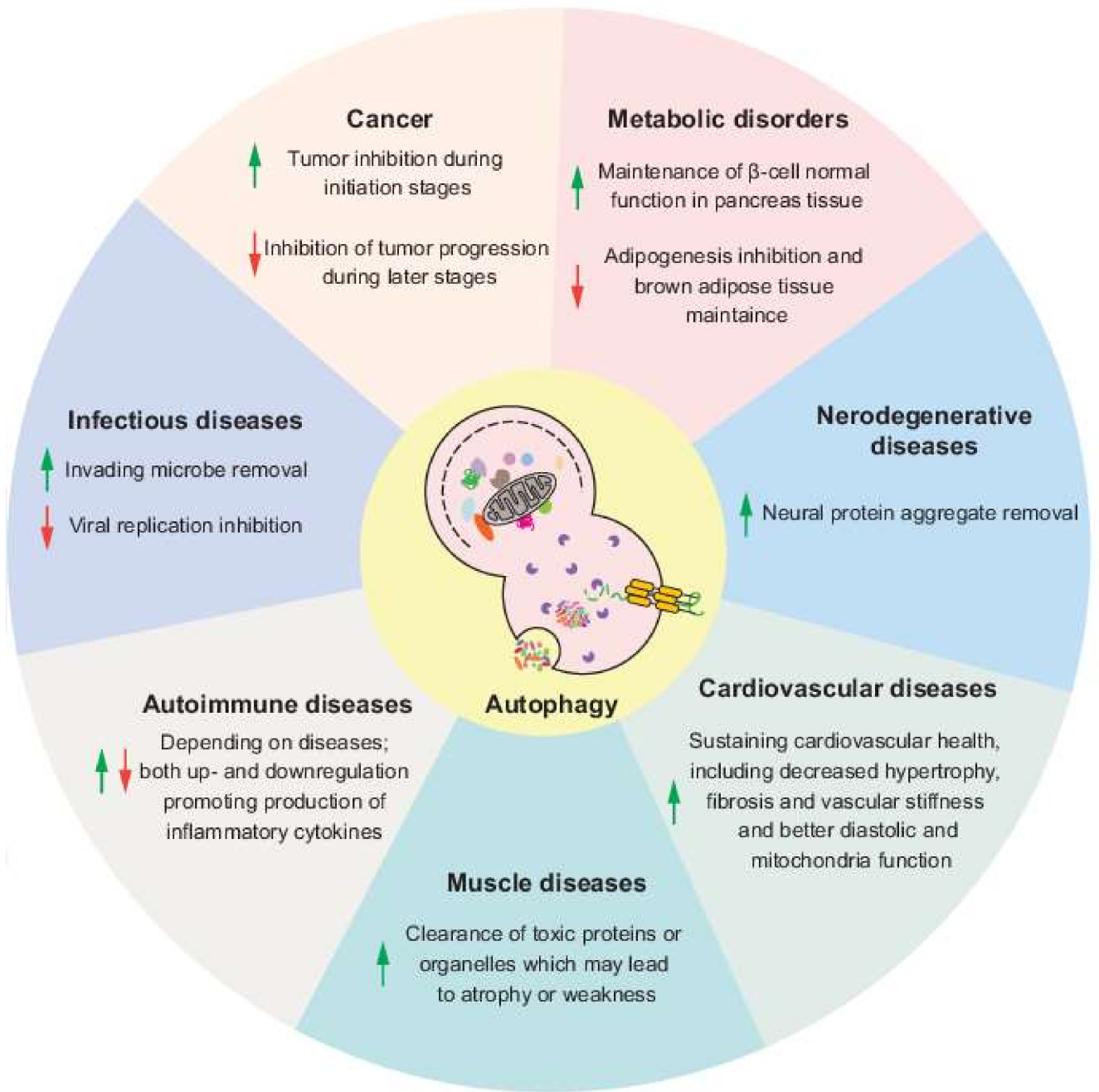

Figure 4. Potential effects of autophagy modulation in different human diseases. Arrows indicate the upregulation or downregulation of autophagy. Because the role of autophagy within one particular disease may be complicated and there are typically studies with controversial conclusions, we only summarize the effect reported from the majority of studies.

Finally, the optimal autophagic markers in the mouse model or human beings are unclear. We have well established guidelines for measuring autophagy in cells [421], but there are few good markers to study autophagy in mouse models and the existing ones have limitations; the situation with humans is even more problematic. These markers are critical for determining how autophagy affects disease initiation or progression and for evaluating the efficiency of autophagy-targeting compounds, especially in a tissue-specific and temporal manner.

Overall, current studies have provided substantial information revealing the emerging roles of autophagy in human diseases. With a deeper understanding of the mechanism of autophagy, we will learn more about how autophagy is associated with human diseases, which will aid in therapy design.

Author Contributions: Writing—original draft preparation: Y.L., D.J.K.; writing—review and editing: Y.L., D.J.K. All authors have read and agreed to the published version of the manuscript.

Funding: This research was funded by the National Institutes of Health grant GM131919.

Conflicts of Interest: The authors declare no conflict of interest. 


$\begin{array}{ll}\text { Abbreviations } \\ \text { AD } & \text { Alzheimer disease } \\ \text { ATG } & \text { autophagy related } \\ \text { BAT } & \text { brown adipose tissue } \\ \text { CQ } & \text { chloroquine } \\ \text { CoV } & \text { coronavirus } \\ \text { CSCs } & \text { cancer stem cells } \\ \text { ECM } & \text { extracellular matrix } \\ \text { FA } & \text { focal adhesion } \\ \text { GWAS } & \text { genome-wide association studies } \\ \text { HCQ } & \text { hydroxychloroquine } \\ \text { HD } & \text { Huntington disease } \\ \text { LAMs } & \text { LIR-motif associated mutations } \\ \text { LIR } & \text { LC3-interacting region } \\ \text { MHC-I } & \text { major histocompability complex class I } \\ \text { mHTT } & \text { mutant HTT (huntingtin) } \\ \text { MSI } & \text { microsatellite instability } \\ \text { MTORC1 } & \text { MTOR complex 1 } \\ \text { OMM } & \text { outer mitochondrial membrane } \\ \text { PD } & \text { Parkinson disease } \\ \text { polyQ } & \text { polyglutamine } \\ \text { PtdIns3K } & \text { phosphatidylinositol 3-kinase } \\ \text { PtdIns3P } & \text { phosphatidylinositol-3-phosphate } \\ \text { ROS } & \text { reactive oxygen species } \\ \text { SCV } & \text { Salmonella-containing vacuole } \\ \text { T2DM } & \text { type 2 diabetes mellitus } \\ \text { WAT } & \text { white adipose tissue } \\ & \end{array}$

\section{References}

1. Wong, P.M.; Puente, C.; Ganley, I.G.; Jiang, X. The ULK1 complex: Sensing nutrient signals for autophagy activation. Autophagy 2013, 9, 124-137. [CrossRef]

2. Nascimbeni, A.C.; Codogno, P.; Morel, E. Phosphatidylinositol-3-phosphate in the regulation of autophagy membrane dynamics. FEBS J. 2017, 284, 1267-1278. [CrossRef] [PubMed]

3. Graef, M.; Friedman, J.R.; Graham, C.; Babu, M.; Nunnari, J. ER exit sites are physical and functional core autophagosome biogenesis components. Mol. Biol. Cell. 2013, 24, 2918-2931. [CrossRef]

4. Hamasaki, M.; Furuta, N.; Matsuda, A.; Nezu, A.; Yamamoto, A.; Fujita, N.; Oomori, H.; Noda, T.; Haraguchi, T.; Hiraoka, Y.; et al. Autophagosomes form at ER-mitochondria contact sites. Nature 2013, 495, 389-393. [CrossRef] [PubMed]

5. Ravikumar, B.; Moreau, K.; Jahreiss, L.; Puri, C.; Rubinsztein, D.C. Plasma membrane contributes to the formation of preautophagosomal structures. Nat. Cell. Biol. 2010, 12, 747-757. [CrossRef] [PubMed]

6. Puri, C.; Renna, M.; Bento, C.F.; Moreau, K.; Rubinsztein, D.C. Diverse autophagosome membrane sources coalesce in recycling endosomes. Cell 2013, 154, 1285-1299. [CrossRef]

7. Puri, C.; Vicinanza, M.; Ashkenazi, A.; Gratian, M.J.; Zhang, Q.; Bento, C.F.; Renna, M.; Menzies, F.M.; Rubinsztein, D.C. The RAB11A-Positive Compartment Is a Primary Platform for Autophagosome Assembly Mediated by WIPI2 Recognition of PI3P-RAB11A. Dev. Cell. 2018, 45, 114-131. [CrossRef] [PubMed]

8. Yin, Z.; Popelka, H.; Lei, Y.; Yang, Y.; Klionsky, D.J. The Roles of Ubiquitin in Mediating Autophagy. Cells 2020, 9, 2025. [CrossRef]

9. Dooley, H.C.; Razi, M.; Polson, H.E.; Girardin, S.E.; Wilson, M.I.; Tooze, S.A. WIPI2 links LC3 conjugation with PI3P, autophagosome formation, and pathogen clearance by recruiting Atg12-5-16L1. Mol. Cell. 2014, 55, 238-252. [CrossRef] [PubMed]

10. Diao, J.; Liu, R.; Rong, Y.; Zhao, M.; Zhang, J.; Lai, Y.; Zhou, Q.; Wilz, L.M.; Li, J.; Vivona, S.; et al. ATG14 promotes membrane tethering and fusion of autophagosomes to endolysosomes. Nature 2015, 520, 563-566. [CrossRef]

11. Gatica, D.; Lahiri, V.; Klionsky, D.J. Cargo recognition and degradation by selective autophagy. Nat. Cell. Biol. 2018, 20, 233-242. [CrossRef] [PubMed]

12. Bakula, D.; Scheibye-Knudsen, M. MitophAging: Mitophagy in Aging and Disease. Front. Cell. Dev. Biol. 2020, 8, 239. [CrossRef] [PubMed]

13. Okamoto, K.; Kondo-Okamoto, N.; Ohsumi, Y. Mitochondria-anchored receptor Atg32 mediates degradation of mitochondria via selective autophagy. Dev. Cell. 2009, 17, 87-97. [CrossRef] [PubMed]

14. Kanki, T.; Wang, K.; Cao, Y.; Baba, M.; Klionsky, D.J. Atg32 is a mitochondrial protein that confers selectivity during mitophagy. Dev. Cell. 2009, 17, 98-109. [CrossRef] [PubMed] 
15. Kondo-Okamoto, N.; Noda, N.N.; Suzuki, S.W.; Nakatogawa, H.; Takahashi, I.; Matsunami, M.; Hashimoto, A.; Inagaki, F.; Ohsumi, Y.; Okamoto, K. Autophagy-related protein 32 acts as autophagic degron and directly initiates mitophagy. J. Biol. Chem. 2012, 287, 10631-10638. [CrossRef] [PubMed]

16. Huang, Y.J.; Klionsky, D.J. Yeast mitophagy: Unanswered questions. Biochim. Biophys. Acta. Gen. Subj. 2021, $1865,129932$. [CrossRef]

17. Sandoval, H.; Thiagarajan, P.; Dasgupta, S.K.; Schumacher, A.; Prchal, J.T.; Chen, M.; Wang, J. Essential role for Nix in autophagic maturation of erythroid cells. Nature 2008, 454, 232-235. [CrossRef] [PubMed]

18. Jin, S.M.; Lazarou, M.; Wang, C.; Kane, L.A.; Narendra, D.P.; Youle, R.J. Mitochondrial membrane potential regulates PINK1 import and proteolytic destabilization by PARL. J. Cell. Biol. 2010, 191, 933-942. [CrossRef] [PubMed]

19. Narendra, D.P.; Jin, S.M.; Tanaka, A.; Suen, D.F.; Gautier, C.A.; Shen, J.; Cookson, M.R.; Youle, R.J. PINK1 is selectively stabilized on impaired mitochondria to activate Parkin. PLoS Biol. 2010, 8, e1000298. [CrossRef] [PubMed]

20. Trempe, J.F.; Sauvé, V.; Grenier, K.; Seirafi, M.; Tang, M.Y.; Ménade, M.; Al-Abdul-Wahid, S.; Krett, J.; Wong, K.; Kozlov, G.; et al. Structure of parkin reveals mechanisms for ubiquitin ligase activation. Science 2013, 340, 1451-1455. [CrossRef]

21. Kondapalli, C.; Kazlauskaite, A.; Zhang, N.; Woodroof, H.I.; Campbell, D.G.; Gourlay, R.; Burchell, L.; Walden, H.; Macartney, T.J.; Deak, M.; et al. PINK1 is activated by mitochondrial membrane potential depolarization and stimulates Parkin E3 ligase activity by phosphorylating Serine 65. Open Biol. 2012, 2, 120080. [CrossRef]

22. Kane, L.A.; Lazarou, M.; Fogel, A.I.; Li, Y.; Yamano, K.; Sarraf, S.A.; Banerjee, S.; Youle, R.J. PINK1 phosphorylates ubiquitin to activate Parkin E3 ubiquitin ligase activity. J. Cell. Biol. 2014, 205, 143-153. [CrossRef] [PubMed]

23. Iguchi, M.; Kujuro, Y.; Okatsu, K.; Koyano, F.; Kosako, H.; Kimura, M.; Suzuki, N.; Uchiyama, S.; Tanaka, K.; Matsuda, N. Parkin-catalyzed ubiquitin-ester transfer is triggered by PINK1-dependent phosphorylation. J. Biol. Chem. 2013, 288, 22019-22032. [CrossRef] [PubMed]

24. Koyano, F.; Okatsu, K.; Kosako, H.; Tamura, Y.; Go, E.; Kimura, M.; Kimura, Y.; Tsuchiya, H.; Yoshihara, H.; Hirokawa, T.; et al. Ubiquitin is phosphorylated by PINK1 to activate parkin. Nature 2014, 510, 162-166. [CrossRef] [PubMed]

25. Heo, J.M.; Ordureau, A.; Paulo, J.A.; Rinehart, J.; Harper, J.W. The PINK1-PARKIN Mitochondrial Ubiquitylation Pathway Drives a Program of OPTN/NDP52 Recruitment and TBK1 Activation to Promote Mitophagy. Mol. Cell. 2015, 60, 7-20. [CrossRef]

26. Lazarou, M.; Sliter, D.A.; Kane, L.A.; Sarraf, S.A.; Wang, C.; Burman, J.L.; Sideris, D.P.; Fogel, A.I.; Youle, R.J. The ubiquitin kinase PINK1 recruits autophagy receptors to induce mitophagy. Nature 2015, 524, 309-314. [CrossRef]

27. Wong, Y.C.; Holzbaur, E.L. Optineurin is an autophagy receptor for damaged mitochondria in parkin-mediated mitophagy that is disrupted by an ALS-linked mutation. Proc. Natl. Acad. Sci. USA 2014, 111, E4439-E4448. [CrossRef]

28. Richter, B.; Sliter, D.A.; Herhaus, L.; Stolz, A.; Wang, C.; Beli, P.; Zaffagnini, G.; Wild, P.; Martens, S.; Wagner, S.A.; et al. Phosphorylation of OPTN by TBK1 enhances its binding to Ub chains and promotes selective autophagy of damaged mitochondria. Proc. Natl. Acad. Sci. USA 2016, 113, 4039-4044. [CrossRef] [PubMed]

29. Novak, I.; Kirkin, V.; McEwan, D.G.; Zhang, J.; Wild, P.; Rozenknop, A.; Rogov, V.; Löhr, F.; Popovic, D.; Occhipinti, A.; et al. Nix is a selective autophagy receptor for mitochondrial clearance. EMBO Rep. 2010, 11, 45-51. [CrossRef]

30. Liu, L.; Feng, D.; Chen, G.; Chen, M.; Zheng, Q.; Song, P.; Ma, Q.; Zhu, C.; Wang, R.; Qi, W.; et al. Mitochondrial outer-membrane protein FUNDC1 mediates hypoxia-induced mitophagy in mammalian cells. Nat. Cell Biol. 2012, 14, 177-185. [CrossRef]

31. Oku, M.; Sakai, Y. Three Distinct Types of Microautophagy Based on Membrane Dynamics and Molecular Machineries. Bioessays 2018, 40, e1800008. [CrossRef] [PubMed]

32. Schuck, S. Microautophagy - distinct molecular mechanisms handle cargoes of many sizes. J. Cell. Sci. 2020, 133. [CrossRef] [PubMed]

33. Kaushik, S.; Cuervo, A.M. The coming of age of chaperone-mediated autophagy. Nat. Rev. Mol. Cell Biol. 2018, 19, 365-381. [CrossRef] [PubMed]

34. Cuervo, A.M.; Wong, E. Chaperone-mediated autophagy: Roles in disease and aging. Cell Res. 2014, 24, 92-104. [CrossRef]

35. Alfaro, I.E.; Albornoz, A.; Molina, A.; Moreno, J.; Cordero, K.; Criollo, A.; Budini, M. Chaperone Mediated Autophagy in the Crosstalk of Neurodegenerative Diseases and Metabolic Disorders. Front. Endocrinol. 2018, 9, 778. [CrossRef]

36. Allen, E.A.; Baehrecke, E.H. Autophagy in animal development. Cell. Death. Differ. 2020, 27, 903-918. [CrossRef]

37. Chen, X.; He, Y.; Lu, F. Autophagy in Stem Cell Biology: A Perspective on Stem Cell Self-Renewal and Differentiation. Stem Cells Int. 2018, 2018, 9131397. [CrossRef] [PubMed]

38. Dong, S.; Wang, Q.; Kao, Y.R.; Diaz, A.; Tasset, I.; Kaushik, S.; Thiruthuvanathan, V.; Zintiridou, A.; Nieves, E.; Dzieciatkowska, M.; et al. Chaperone-mediated autophagy sustains haematopoietic stem-cell function. Nature 2021, 591, 117-123. [CrossRef]

39. Germic, N.; Frangez, Z.; Yousefi, S.; Simon, H.U. Regulation of the innate immune system by autophagy: Monocytes, macrophages, dendritic cells and antigen presentation. Cell. Death. Differ. 2019, 26, 715-727. [CrossRef]

40. Liang, X.H.; Jackson, S.; Seaman, M.; Brown, K.; Kempkes, B.; Hibshoosh, H.; Levine, B. Induction of autophagy and inhibition of tumorigenesis by beclin 1. Nature 1999, 402, 672-676. [CrossRef]

41. Ding, Z.B.; Shi, Y.H.; Zhou, J.; Qiu, S.J.; Xu, Y.; Dai, Z.; Shi, G.M.; Wang, X.Y.; Ke, A.W.; Wu, B.; et al. Association of autophagy defect with a malignant phenotype and poor prognosis of hepatocellular carcinoma. Cancer Res. 2008, 68, 9167-9175. [CrossRef] [PubMed] 
42. Zhou, W.H.; Tang, F.; Xu, J.; Wu, X.; Yang, S.B.; Feng, Z.Y.; Ding, Y.G.; Wan, X.B.; Guan, Z.; Li, H.G.; et al. Low expression of Beclin 1, associated with high Bcl-xL, predicts a malignant phenotype and poor prognosis of gastric cancer. Autophagy 2012, 8, 389-400. [CrossRef] [PubMed]

43. Nicotra, G.; Mercalli, F.; Peracchio, C.; Castino, R.; Follo, C.; Valente, G.; Isidoro, C. Autophagy-active beclin-1 correlates with favourable clinical outcome in non-Hodgkin lymphomas. Mod. Pathol. 2010, 23, 937-950. [CrossRef]

44. Qu, X.; Yu, J.; Bhagat, G.; Furuya, N.; Hibshoosh, H.; Troxel, A.; Rosen, J.; Eskelinen, E.L.; Mizushima, N.; Ohsumi, Y.; et al. Promotion of tumorigenesis by heterozygous disruption of the beclin 1 autophagy gene. J. Clin. Invest. 2003, 112, 1809-1820. [CrossRef] [PubMed]

45. Yue, Z.; Jin, S.; Yang, C.; Levine, A.J.; Heintz, N. Beclin 1, an autophagy gene essential for early embryonic development, is a haploinsufficient tumor suppressor. Proc. Natl. Acad. Sci. USA 2003, 100, 15077-15082. [CrossRef] [PubMed]

46. He, C.; Levine, B. The Beclin 1 interactome. Curr. Opin. Cell Biol. 2010, 22, 140-149. [CrossRef]

47. Kim, M.S.; Jeong, E.G.; Ahn, C.H.; Kim, S.S.; Lee, S.H.; Yoo, N.J. Frameshift mutation of UVRAG, an autophagy-related gene, in gastric carcinomas with microsatellite instability. Hum. Pathol. 2008, 39, 1059-1063. [CrossRef] [PubMed]

48. He, S.; Zhao, Z.; Yang, Y.; O'Connell, D.; Zhang, X.; Oh, S.; Ma, B.; Lee, J.H.; Zhang, T.; Varghese, B.; et al. Truncating mutation in the autophagy gene UVRAG confers oncogenic properties and chemosensitivity in colorectal cancers. Nat. Commun. 2015, 6, 7839. [CrossRef] [PubMed]

49. Takahashi, Y.; Coppola, D.; Matsushita, N.; Cualing, H.D.; Sun, M.; Sato, Y.; Liang, C.; Jung, J.U.; Cheng, J.Q.; Mulé, J.J.; et al. Bif-1 interacts with Beclin 1 through UVRAG and regulates autophagy and tumorigenesis. Nat. Cell Biol. 2007, 9, 1142-1151. [CrossRef]

50. Fimia, G.M.; Di Bartolomeo, S.; Piacentini, M.; Cecconi, F. Unleashing the Ambra1-Beclin 1 complex from dynein chains: Ulk1 sets Ambra1 free to induce autophagy. Autophagy 2011, 7, 115-117. [CrossRef]

51. Cianfanelli, V.; Fuoco, C.; Lorente, M.; Salazar, M.; Quondamatteo, F.; Gherardini, P.F.; De Zio, D.; Nazio, F.; Antonioli, M.; D'Orazio, M.; et al. AMBRA1 links autophagy to cell proliferation and tumorigenesis by promoting c-Myc dephosphorylation and degradation. Nat. Cell Biol. 2015, 17, 706. [CrossRef]

52. Maiani, E.; Milletti, G.; Nazio, F.; Holdgaard, S.G.; Bartkova, J.; Rizza, S.; Cianfanelli, V.; Lorente, M.; Simoneschi, D.; Di Marco, M.; et al. AMBRA1 regulates cyclin D to guard S-phase entry and genomic integrity. Nature 2021, 592, 799-803. [CrossRef] [PubMed]

53. Velho, S.; Fernandes, M.S.; Leite, M.; Figueiredo, C.; Seruca, R. Causes and consequences of microsatellite instability in gastric carcinogenesis. World J. Gastroenterol. 2014, 20, 16433-16442. [CrossRef] [PubMed]

54. Kang, M.R.; Kim, M.S.; Oh, J.E.; Kim, Y.R.; Song, S.Y.; Kim, S.S.; Ahn, C.H.; Yoo, N.J.; Lee, S.H. Frameshift mutations of autophagy-related genes ATG2B, ATG5, ATG9B and ATG12 in gastric and colorectal cancers with microsatellite instability. J. Pathol. 2009, 217, 702-706. [CrossRef] [PubMed]

55. Jiang, P.; Nishimura, T.; Sakamaki, Y.; Itakura, E.; Hatta, T.; Natsume, T.; Mizushima, N. The HOPS complex mediates autophagosome-lysosome fusion through interaction with syntaxin 17. Mol. Biol. Cell. 2014, 25, 1327-1337. [CrossRef]

56. An, C.H.; Kim, Y.R.; Kim, H.S.; Kim, S.S.; Yoo, N.J.; Lee, S.H. Frameshift mutations of vacuolar protein sorting genes in gastric and colorectal cancers with microsatellite instability. Hum. Pathol. 2012, 43, 40-47. [CrossRef]

57. Wible, D.J.; Chao, H.P.; Tang, D.G.; Bratton, S.B. Cancer mutations and alternative mRNA splicing reveal a conjugation switch that regulates ATG12-ATG5-ATG16L1 complex assembly and autophagy. Cell Discov. 2019, 5, 42. [CrossRef] [PubMed]

58. Lebovitz, C.B.; Robertson, A.G.; Goya, R.; Jones, S.J.; Morin, R.D.; Marra, M.A.; Gorski, S.M. Cross-cancer profiling of molecular alterations within the human autophagy interaction network. Autophagy 2015, 11, 1668-1687. [CrossRef]

59. Takamura, A.; Komatsu, M.; Hara, T.; Sakamoto, A.; Kishi, C.; Waguri, S.; Eishi, Y.; Hino, O.; Tanaka, K.; Mizushima, N. Autophagy-deficient mice develop multiple liver tumors. Genes Dev. 2011, 25, 795-800. [CrossRef]

60. Yang, A.; Rajeshkumar, N.V.; Wang, X.; Yabuuchi, S.; Alexander, B.M.; Chu, G.C.; Von Hoff, D.D.; Maitra, A.; Kimmelman, A.C. Autophagy is critical for pancreatic tumor growth and progression in tumors with p53 alterations. Cancer Discov. 2014, 4, 905-913. [CrossRef]

61. Guo, J.Y.; Karsli-Uzunbas, G.; Mathew, R.; Aisner, S.C.; Kamphorst, J.J.; Strohecker, A.M.; Chen, G.; Price, S.; Lu, W.; Teng, X.; et al. Autophagy suppresses progression of K-ras-induced lung tumors to oncocytomas and maintains lipid homeostasis. Genes Dev. 2013, 27, 1447-1461. [CrossRef] [PubMed]

62. Karsli-Uzunbas, G.; Guo, J.Y.; Price, S.; Teng, X.; Laddha, S.V.; Khor, S.; Kalaany, N.Y.; Jacks, T.; Chan, C.S.; Rabinowitz, J.D.; et al. Autophagy is required for glucose homeostasis and lung tumor maintenance. Cancer Discov. 2014, 4, 914-927. [CrossRef]

63. Han, Z.; Zhang, W.; Ning, W.; Wang, C.; Deng, W.; Li, Z.; Shang, Z.; Shen, X.; Liu, X.; Baba, O.; et al. Model-based analysis uncovers mutations altering autophagy selectivity in human cancer. Nat. Commun. 2021, 12, 3258. [CrossRef] [PubMed]

64. Zaman, A.; Wu, W.; Bivona, T.G. Targeting Oncogenic BRAF: Past, Present, and Future. Cancers 2019, 11, 1197. [CrossRef]

65. Yoshioka, A.; Miyata, H.; Doki, Y.; Yamasaki, M.; Sohma, I.; Gotoh, K.; Takiguchi, S.; Fujiwara, Y.; Uchiyama, Y.; Monden, M. LC3, an autophagosome marker, is highly expressed in gastrointestinal cancers. Int. J. Oncol. 2008, 33, 461-468. [CrossRef]

66. Perera, R.M.; Stoykova, S.; Nicolay, B.N.; Ross, K.N.; Fitamant, J.; Boukhali, M.; Lengrand, J.; Deshpande, V.; Selig, M.K.; Ferrone, C.R.; et al. Transcriptional control of autophagy-lysosome function drives pancreatic cancer metabolism. Nature 2015, 524, 361-365. [CrossRef]

67. Yang, S.; Wang, X.; Contino, G.; Liesa, M.; Sahin, E.; Ying, H.; Bause, A.; Li, Y.; Stommel, J.M.; Dell'antonio, G.; et al. Pancreatic cancers require autophagy for tumor growth. Genes Dev. 2011, 25, 717-729. [CrossRef] [PubMed] 
68. Wei, H.; Wei, S.; Gan, B.; Peng, X.; Zou, W.; Guan, J.L. Suppression of autophagy by FIP200 deletion inhibits mammary tumorigenesis. Genes Dev. 2011, 25, 1510-1527. [CrossRef] [PubMed]

69. Wei, H.; Wang, C.; Croce, C.M.; Guan, J.L. p62/SQSTM1 synergizes with autophagy for tumor growth in vivo. Genes Dev. 2014, 28, 1204-1216. [CrossRef] [PubMed]

70. Gammoh, N.; Fraser, J.; Puente, C.; Syred, H.M.; Kang, H.; Ozawa, T.; Lam, D.; Acosta, J.C.; Finch, A.J.; Holland, E.; et al. Suppression of autophagy impedes glioblastoma development and induces senescence. Autophagy 2016, 12, 1431-1439. [CrossRef] [PubMed]

71. Lévy, J.; Cacheux, W.; Bara, M.A.; L’Hermitte, A.; Lepage, P.; Fraudeau, M.; Trentesaux, C.; Lemarchand, J.; Durand, A.; Crain, A.M.; et al. Intestinal inhibition of Atg7 prevents tumour initiation through a microbiome-influenced immune response and suppresses tumour growth. Nat. Cell Biol. 2015, 17, 1062-1073. [CrossRef]

72. Santanam, U.; Banach-Petrosky, W.; Abate-Shen, C.; Shen, M.M.; White, E.; DiPaola, R.S. Atg7 cooperates with Pten loss to drive prostate cancer tumor growth. Genes Dev. 2016, 30, 399-407. [CrossRef] [PubMed]

73. Poillet-Perez, L.; White, E. Role of tumor and host autophagy in cancer metabolism. Genes Dev. 2019, 33, 610-619. [CrossRef] [PubMed]

74. Guo, J.Y.; Chen, H.Y.; Mathew, R.; Fan, J.; Strohecker, A.M.; Karsli-Uzunbas, G.; Kamphorst, J.J.; Chen, G.; Lemons, J.M.; Karantza, V.; et al. Activated Ras requires autophagy to maintain oxidative metabolism and tumorigenesis. Genes Dev. 2011, 25, 460-470. [CrossRef] [PubMed]

75. Strohecker, A.M.; Guo, J.Y.; Karsli-Uzunbas, G.; Price, S.M.; Chen, G.J.; Mathew, R.; McMahon, M.; White, E. Autophagy sustains mitochondrial glutamine metabolism and growth of BrafV600E-driven lung tumors. Cancer Discov. 2013, 3, 1272-1285. [CrossRef] [PubMed]

76. Guo, J.Y.; Teng, X.; Laddha, S.V.; Ma, S.; Van Nostrand, S.C.; Yang, Y.; Khor, S.; Chan, C.S.; Rabinowitz, J.D.; White, E. Autophagy provides metabolic substrates to maintain energy charge and nucleotide pools in Ras-driven lung cancer cells. Genes Dev 2016, 30, 1704-1717. [CrossRef] [PubMed]

77. Bhatt, V.; Khayati, K.; Hu, Z.S.; Lee, A.; Kamran, W.; Su, X.; Guo, J.Y. Autophagy modulates lipid metabolism to maintain metabolic flexibility for. Genes Dev. 2019, 33, 150-165. [CrossRef]

78. Huo, Y.; Cai, H.; Teplova, I.; Bowman-Colin, C.; Chen, G.; Price, S.; Barnard, N.; Ganesan, S.; Karantza, V.; White, E.; et al Autophagy opposes p53-mediated tumor barrier to facilitate tumorigenesis in a model of PALB2-associated hereditary breast cancer. Cancer Discov. 2013, 3, 894-907. [CrossRef] [PubMed]

79. Rao, S.; Tortola, L.; Perlot, T.; Wirnsberger, G.; Novatchkova, M.; Nitsch, R.; Sykacek, P.; Frank, L.; Schramek, D.; Komnenovic, V.; et al. A dual role for autophagy in a murine model of lung cancer. Nat. Commun. 2014, 5, 3056. [CrossRef]

80. Rosenfeldt, M.T.; O’Prey, J.; Morton, J.P.; Nixon, C.; MacKay, G.; Mrowinska, A.; Au, A.; Rai, T.S.; Zheng, L.; Ridgway, R.; et al. p53 status determines the role of autophagy in pancreatic tumour development. Nature 2013, 504, 296-300. [CrossRef] [PubMed]

81. Fares, J.; Fares, M.Y.; Khachfe, H.H.; Salhab, H.A.; Fares, Y. Molecular principles of metastasis: A hallmark of cancer revisited. Signal Transduct. Target. Ther. 2020, 5, 28. [CrossRef]

82. Lazova, R.; Camp, R.L.; Klump, V.; Siddiqui, S.F.; Amaravadi, R.K.; Pawelek, J.M. Punctate LC3B expression is a common feature of solid tumors and associated with proliferation, metastasis, and poor outcome. Clin. Cancer Res. 2012, 18, 370-379. [CrossRef]

83. Zhao, H.; Yang, M.; Zhao, J.; Wang, J.; Zhang, Y.; Zhang, Q. High expression of LC3B is associated with progression and poor outcome in triple-negative breast cancer. Med. Oncol. 2013, 30, 475. [CrossRef]

84. Nagano, M.; Hoshino, D.; Koshikawa, N.; Akizawa, T.; Seiki, M. Turnover of focal adhesions and cancer cell migration. Int. J. Cell. Biol. 2012, 2012, 310616. [CrossRef]

85. Chang, C.H.; Bijian, K.; Qiu, D.; Su, J.; Saad, A.; Dahabieh, M.S.; Miller, W.H.; Alaoui-Jamali, M.A. Endosomal sorting and c-Cbl targeting of paxillin to autophagosomes regulate cell-matrix adhesion turnover in human breast cancer cells. Oncotarget 2017, 8, 31199-31214. [CrossRef]

86. Sharifi, M.N.; Mowers, E.E.; Drake, L.E.; Collier, C.; Chen, H.; Zamora, M.; Mui, S.; Macleod, K.F. Autophagy Promotes Focal Adhesion Disassembly and Cell Motility of Metastatic Tumor Cells through the Direct Interaction of Paxillin with LC3. Cell. Rep. 2016, 15, 1660-1672. [CrossRef]

87. Assar, E.A.; Tumbarello, D.A. Loss of the Essential Autophagy Regulators FIP200 or Atg5 Leads to Distinct Effects on Focal Adhesion Composition and Organization. Front. Cell. Dev. Biol. 2020, 8, 733. [CrossRef] [PubMed]

88. Caino, M.C.; Chae, Y.C.; Vaira, V.; Ferrero, S.; Nosotti, M.; Martin, N.M.; Weeraratna, A.; O'Connell, M.; Jernigan, D.; Fatatis, A.; et al. Metabolic stress regulates cytoskeletal dynamics and metastasis of cancer cells. J. Clin. Invest. 2013, 123, 2907-2920. [CrossRef]

89. Kenific, C.M.; Stehbens, S.J.; Goldsmith, J.; Leidal, A.M.; Faure, N.; Ye, J.; Wittmann, T.; Debnath, J. NBR1 enables autophagydependent focal adhesion turnover. J. Cell. Biol. 2016, 212, 577-590. [CrossRef] [PubMed]

90. Marsh, T.; Kenific, C.M.; Suresh, D.; Gonzalez, H.; Shamir, E.R.; Mei, W.; Tankka, A.; Leidal, A.M.; Kalavacherla, S.; Woo, K.; et al. Autophagic Degradation of NBR1 Restricts Metastatic Outgrowth during Mammary Tumor Progression. Dev. Cell. 2020, 52, 591-604. [CrossRef]

91. Peng, Y.F.; Shi, Y.H.; Shen, Y.H.; Ding, Z.B.; Ke, A.W.; Zhou, J.; Qiu, S.J.; Fan, J. Promoting colonization in metastatic HCC cells by modulation of autophagy. PLoS ONE 2013, 8, e74407. [CrossRef] [PubMed] 
92. Sanchez-Martin, P.; Sou, Y.S.; Kageyama, S.; Koike, M.; Waguri, S.; Komatsu, M. NBR1-mediated p62-liquid droplets enhance the Keap1-Nrf2 system. EMBO Rep. 2020, 21, e48902. [CrossRef]

93. Saito, T.; Ichimura, Y.; Taguchi, K.; Suzuki, T.; Mizushima, T.; Takagi, K.; Hirose, Y.; Nagahashi, M.; Iso, T.; Fukutomi, T.; et al. p62/Sqstm1 promotes malignancy of HCV-positive hepatocellular carcinoma through Nrf2-dependent metabolic reprogramming. Nat. Commun. 2016, 7, 12030. [CrossRef]

94. Taguchi, K.; Yamamoto, M. The KEAP1-NRF2 System in Cancer. Front. Oncol. 2017, 7, 85. [CrossRef] [PubMed]

95. Valastyan, S.; Weinberg, R.A. Tumor metastasis: Molecular insights and evolving paradigms. Cell 2011, 147, 275-292. [CrossRef]

96. Li, J.; Yang, B.; Zhou, Q.; Wu, Y.; Shang, D.; Guo, Y.; Song, Z.; Zheng, Q.; Xiong, J. Autophagy promotes hepatocellular carcinoma cell invasion through activation of epithelial-mesenchymal transition. Carcinogenesis 2013, 34, 1343-1351. [CrossRef] [PubMed]

97. Kim, Y.H.; Baek, S.H.; Kim, E.K.; Ha, J.M.; Jin, S.Y.; Lee, H.S.; Ha, H.K.; Song, S.H.; Kim, S.J.; Shin, H.K.; et al. Uncoordinated 51-like kinase 2 signaling pathway regulates epithelial-mesenchymal transition in A549 lung cancer cells. FEBS Lett. 2016, 590, 1365-1374. [CrossRef]

98. Zhang, W.; Yuan, W.; Song, J.; Wang, S.; Gu, X. LncRNA CPS1-IT1 suppresses EMT and metastasis of colorectal cancer by inhibiting hypoxia-induced autophagy through inactivation of HIF-1 $\alpha$. Biochimie 2018, 144, 21-27. [CrossRef]

99. Ren, T.; Zheng, B.; Huang, Y.; Wang, S.; Bao, X.; Liu, K.; Guo, W. Osteosarcoma cell intrinsic PD-L2 signals promote invasion and metastasis via the RhoA-ROCK-LIMK2 and autophagy pathways. Cell. Death Dis. 2019, 10, 261. [CrossRef] [PubMed]

100. Alizadeh, J.; Glogowska, A.; Thliveris, J.; Kalantari, F.; Shojaei, S.; Hombach-Klonisch, S.; Klonisch, T.; Ghavami, S. Autophagy modulates transforming growth factor beta 1 induced epithelial to mesenchymal transition in non-small cell lung cancer cells. Biochim. Biophys. Acta Mol. Cell Res. 2018, 1865, 749-768. [CrossRef]

101. Kiyono, K.; Suzuki, H.I.; Matsuyama, H.; Morishita, Y.; Komuro, A.; Kano, M.R.; Sugimoto, K.; Miyazono, K. Autophagy is activated by TGF-beta and potentiates TGF-beta-mediated growth inhibition in human hepatocellular carcinoma cells. Cancer Res. 2009, 69, 8844-8852. [CrossRef]

102. Lv, Q.; Wang, W.; Xue, J.; Hua, F.; Mu, R.; Lin, H.; Yan, J.; Lv, X.; Chen, X.; Hu, Z.W. DEDD interacts with PI3KC3 to activate autophagy and attenuate epithelial-mesenchymal transition in human breast cancer. Cancer Res. 2012, 72, 3238-3250. [CrossRef]

103. Grassi, G.; Di Caprio, G.; Santangelo, L.; Fimia, G.M.; Cozzolino, A.M.; Komatsu, M.; Ippolito, G.; Tripodi, M.; Alonzi, T. Autophagy regulates hepatocyte identity and epithelial-to-mesenchymal and mesenchymal-to-epithelial transitions promoting Snail degradation. Cell Death Dis. 2015, 6, e1880. [CrossRef] [PubMed]

104. Qiang, L.; Zhao, B.; Ming, M.; Wang, N.; He, T.C.; Hwang, S.; Thorburn, A.; He, Y.Y. Regulation of cell proliferation and migration by 62 through stabilization of Twist1. Proc. Natl. Acad. Sci. USA 2014, 111, 9241-9246. [CrossRef] [PubMed]

105. Karimi Roshan, M.; Soltani, A.; Soleimani, A.; Rezaie Kahkhaie, K.; Afshari, A.R.; Soukhtanloo, M. Role of AKT and mTOR signaling pathways in the induction of epithelial-mesenchymal transition (EMT) process. Biochimie 2019, 165, 229-234. [CrossRef]

106. Dower, C.M.; Wills, C.A.; Frisch, S.M.; Wang, H.G. Mechanisms and context underlying the role of autophagy in cancer metastasis. Autophagy 2018, 14, 1110-1128. [CrossRef] [PubMed]

107. Gilmore, A.P. Anoikis. Cell Death Differ. 2005, 12 (Suppl. 2), 1473-1477. [CrossRef]

108. Avivar-Valderas, A.; Salas, E.; Bobrovnikova-Marjon, E.; Diehl, J.A.; Nagi, C.; Debnath, J.; Aguirre-Ghiso, J.A. PERK integrates autophagy and oxidative stress responses to promote survival during extracellular matrix detachment. Mol. Cell. Biol. 2011, 31, 3616-3629. [CrossRef] [PubMed]

109. Avivar-Valderas, A.; Bobrovnikova-Marjon, E.; Alan Diehl, J.; Bardeesy, N.; Debnath, J.; Aguirre-Ghiso, J.A. Regulation of autophagy during ECM detachment is linked to a selective inhibition of mTORC1 by PERK. Oncogene 2013, 32, 4932-4940. [CrossRef] [PubMed]

110. Fung, C.; Lock, R.; Gao, S.; Salas, E.; Debnath, J. Induction of autophagy during extracellular matrix detachment promotes cell survival. Mol. Biol. Cell. 2008, 19, 797-806. [CrossRef]

111. Chen, N.; Debnath, J. IкB kinase complex (IKK) triggers detachment-induced autophagy in mammary epithelial cells independently of the PI3K-AKT-MTORC1 pathway. Autophagy 2013, 9, 1214-1227. [CrossRef]

112. Zhu, H.D.; Liu, L.; Deng, H.; Li, Z.B.; Sheng, J.Q.; He, X.X.; Tian, D.A.; Li, P.Y. Astrocyte elevated gene 1 (AEG-1) promotes anoikis resistance and metastasis by inducing autophagy in hepatocellular carcinoma. J. Cell. Physiol. 2020, 235, 5084-5095. [CrossRef]

113. Paoli, P.; Giannoni, E.; Chiarugi, P. Anoikis molecular pathways and its role in cancer progression. Biochim. Biophys. Acta 2013, 1833, 3481-3498. [CrossRef] [PubMed]

114. Zhou, F.; Yang, Y.; Xing, D. Bcl-2 and Bcl-xL play important roles in the crosstalk between autophagy and apoptosis. FEBS J. 2011, 278, 403-413. [CrossRef]

115. Buchheit, C.L.; Angarola, B.L.; Steiner, A.; Weigel, K.J.; Schafer, Z.T. Anoikis evasion in inflammatory breast cancer cells is mediated by Bim-EL sequestration. Cell Death Differ. 2015, 22, 1275-1286. [CrossRef] [PubMed]

116. Reginato, M.J.; Mills, K.R.; Paulus, J.K.; Lynch, D.K.; Sgroi, D.C.; Debnath, J.; Muthuswamy, S.K.; Brugge, J.S. Integrins and EGFR coordinately regulate the pro-apoptotic protein Bim to prevent anoikis. Nat. Cell Biol. 2003, 5, 733-740. [CrossRef]

117. Martinez-Lopez, N.; Athonvarangkul, D.; Mishall, P.; Sahu, S.; Singh, R. Autophagy proteins regulate ERK phosphorylation. Nat. Commun. 2013, 4, 2799. [CrossRef]

118. Chaffer, C.L.; Weinberg, R.A. A perspective on cancer cell metastasis. Science 2011, 331, 1559-1564. [CrossRef] [PubMed] 
119. Gong, C.; Bauvy, C.; Tonelli, G.; Yue, W.; Deloménie, C.; Nicolas, V.; Zhu, Y.; Domergue, V.; Marin-Esteban, V.; Tharinger, H.; et al. Beclin 1 and autophagy are required for the tumorigenicity of breast cancer stem-like/progenitor cells. Oncogene 2013, 32, 2261-2272. [CrossRef] [PubMed]

120. Buccarelli, M.; Marconi, M.; Pacioni, S.; De Pascalis, I.; D’Alessandris, Q.G.; Martini, M.; Ascione, B.; Malorni, W.; Larocca, L.M.; Pallini, R.; et al. Inhibition of autophagy increases susceptibility of glioblastoma stem cells to temozolomide by igniting ferroptosis. Cell. Death Dis. 2018, 9, 841. [CrossRef] [PubMed]

121. Zhang, D.; Zhao, Q.; Sun, H.; Yin, L.; Wu, J.; Xu, J.; He, T.; Yang, C.; Liang, C. Defective autophagy leads to the suppression of stem-like features of CD271. J. Biomed. Sci. 2016, 23, 82. [CrossRef] [PubMed]

122. Huang, C.K.; Yang, C.Y.; Jeng, Y.M.; Chen, C.L.; Wu, H.H.; Chang, Y.C.; Ma, C.; Kuo, W.H.; Chang, K.J.; Shew, J.Y.; et al. Autocrine/paracrine mechanism of interleukin-17B receptor promotes breast tumorigenesis through NF-kB-mediated antiapoptotic pathway. Oncogene 2014, 33, 2968-2977. [CrossRef] [PubMed]

123. Bie, Q.; Song, H.; Chen, X.; Yang, X.; Shi, S.; Zhang, L.; Zhao, R.; Wei, L.; Zhang, B.; Xiong, H. IL-17B/IL-17RB signaling cascade contributes to self-renewal and tumorigenesis of cancer stem cells by regulating Beclin-1 ubiquitination. Oncogene 2021, 40, 2200-2216. [CrossRef] [PubMed]

124. Bortnik, S.; Tessier-Cloutier, B.; Leung, S.; Xu, J.; Asleh, K.; Burugu, S.; Magrill, J.; Greening, K.; Derakhshan, F.; Yip, S.; et al. Differential expression and prognostic relevance of autophagy-related markers ATG4B, GABARAP, and LC3B in breast cancer. Breast Cancer Res. Treat. 2020, 183, 525-547. [CrossRef] [PubMed]

125. Wang, J.; Liu, D.; Sun, Z.; Ye, T.; Li, J.; Zeng, B.; Zhao, Q.; Rosie Xing, H. Autophagy augments the self-renewal of lung cancer stem cells by the degradation of ubiquitinated p53. Cell. Death Dis. 2021, 12, 98. [CrossRef] [PubMed]

126. Maycotte, P.; Jones, K.L.; Goodall, M.L.; Thorburn, J.; Thorburn, A. Autophagy Supports Breast Cancer Stem Cell Maintenance by Regulating IL6 Secretion. Mol. Cancer Res. 2015, 13, 651-658. [CrossRef] [PubMed]

127. Iliopoulos, D.; Hirsch, H.A.; Wang, G.; Struhl, K. Inducible formation of breast cancer stem cells and their dynamic equilibrium with non-stem cancer cells via IL6 secretion. Proc. Natl. Acad. Sci. USA 2011, 108, 1397-1402. [CrossRef] [PubMed]

128. Yeo, S.K.; Wen, J.; Chen, S.; Guan, J.L. Autophagy Differentially Regulates Distinct Breast Cancer Stem-like Cells in Murine Models via EGFR/Stat3 and Tgf $\beta /$ Smad Signaling. Cancer Res. 2016, 76, 3397-3410. [CrossRef] [PubMed]

129. Peng, Q.; Qin, J.; Zhang, Y.; Cheng, X.; Wang, X.; Lu, W.; Xie, X.; Zhang, S. Autophagy maintains the stemness of ovarian cancer stem cells by FOXA2. J. Exp. Clin. Cancer Res. 2017, 36, 171. [CrossRef] [PubMed]

130. Perez-Balaguer, A.; Ortiz-Martínez, F.; García-Martínez, A.; Pomares-Navarro, C.; Lerma, E.; Peiró, G. FOXA2 mRNA expression is associated with relapse in patients with Triple-Negative/Basal-like breast carcinoma. Breast Cancer Res. Treat. 2015, 153, 465-474. [CrossRef]

131. Ghatak, D.; Das Ghosh, D.; Roychoudhury, S. Cancer Stemness: p53 at the Wheel. Front Oncol. 2020, 10, 604124. [CrossRef]

132. Sharif, T.; Martell, E.; Dai, C.; Kennedy, B.E.; Murphy, P.; Clements, D.R.; Kim, Y.; Lee, P.W.; Gujar, S.A. Autophagic homeostasis is required for the pluripotency of cancer stem cells. Autophagy 2017, 13, 264-284. [CrossRef] [PubMed]

133. Sosa, M.S.; Bragado, P.; Aguirre-Ghiso, J.A. Mechanisms of disseminated cancer cell dormancy: An awakening field. Nat. Rev. Cancer 2014, 14, 611-622. [CrossRef] [PubMed]

134. Yeh, A.C.; Ramaswamy, S. Mechanisms of Cancer Cell Dormancy-Another Hallmark of Cancer? Cancer Res. 2015, 75, 5014-5022. [CrossRef] [PubMed]

135. Phan, T.G.; Croucher, P.I. The dormant cancer cell life cycle. Nat. Rev. Cancer 2020, 20, 398-411. [CrossRef]

136. Akkoc, Y.; Peker, N.; Akcay, A.; Gozuacik, D. Autophagy and Cancer Dormancy. Front. Oncol. 2021, 11, 627023. [CrossRef] [PubMed]

137. Stewart, C.; Ralyea, C.; Lockwood, S. Ovarian Cancer: An Integrated Review. Semin. Oncol. Nurs. 2019, 35, 151-156. [CrossRef] [PubMed]

138. Lu, Z.; Baquero, M.T.; Yang, H.; Yang, M.; Reger, A.S.; Kim, C.; Levine, D.A.; Clarke, C.H.; Liao, W.S.; Bast, R.C. DIRAS3 regulates the autophagosome initiation complex in dormant ovarian cancer cells. Autophagy 2014, 10, 1071-1092. [CrossRef] [PubMed]

139. Lu, Z.; Luo, R.Z.; Lu, Y.; Zhang, X.; Yu, Q.; Khare, S.; Kondo, S.; Kondo, Y.; Yu, Y.; Mills, G.B.; et al. The tumor suppressor gene ARHI regulates autophagy and tumor dormancy in human ovarian cancer cells. J. Clin. Investig. 2008, 118, 3917-3929. [CrossRef]

140. Correa, R.J.; Valdes, Y.R.; Peart, T.M.; Fazio, E.N.; Bertrand, M.; McGee, J.; Préfontaine, M.; Sugimoto, A.; DiMattia, G.E.; Shepherd, T.G. Combination of AKT inhibition with autophagy blockade effectively reduces ascites-derived ovarian cancer cell viability. Carcinogenesis 2014, 35, 1951-1961. [CrossRef]

141. Washington, M.N.; Suh, G.; Orozco, A.F.; Sutton, M.N.; Yang, H.; Wang, Y.; Mao, W.; Millward, S.; Ornelas, A.; Atkinson, N.; et al. ARHI (DIRAS3)-mediated autophagy-associated cell death enhances chemosensitivity to cisplatin in ovarian cancer cell lines and xenografts. Cell. Death Dis. 2015, 6, e1836. [CrossRef]

142. La Belle Flynn, A.; Calhoun, B.C.; Sharma, A.; Chang, J.C.; Almasan, A.; Schiemann, W.P. Autophagy inhibition elicits emergence from metastatic dormancy by inducing and stabilizing Pfkfb3 expression. Nat. Commun. 2019, 10, 3668. [CrossRef]

143. Vera-Ramirez, L.; Vodnala, S.K.; Nini, R.; Hunter, K.W.; Green, J.E. Autophagy promotes the survival of dormant breast cancer cells and metastatic tumour recurrence. Nat. Commun. 2018, 9, 1944. [CrossRef]

144. Wang, L.; Shang, Z.; Zhou, Y.; Hu, X.; Chen, Y.; Fan, Y.; Wei, X.; Wu, L.; Liang, Q.; Zhang, J.; et al. Autophagy mediates glucose starvation-induced glioblastoma cell quiescence and chemoresistance through coordinating cell metabolism, cell cycle, and survival. Cell. Death Dis. 2018, 9, 213. [CrossRef] 
145. Aqbi, H.F.; Tyutyunyk-Massey, L.; Keim, R.C.; Butler, S.E.; Thekkudan, T.; Joshi, S.; Smith, T.M.; Bandyopadhyay, D.; Idowu, M.O.; Bear, H.D.; et al. Autophagy-deficient breast cancer shows early tumor recurrence and escape from dormancy. Oncotarget 2018, 9, 22113-22122. [CrossRef]

146. Shi, L.; Pan, H.; Liu, Z.; Xie, J.; Han, W. Roles of PFKFB3 in cancer. Signal Transduct. Target. Ther. 2017, 2, 17044. [CrossRef]

147. Ueda, S.; Takanashi, M.; Sudo, K.; Kanekura, K.; Kuroda, M. miR-27a ameliorates chemoresistance of breast cancer cells by disruption of reactive oxygen species homeostasis and impairment of autophagy. Lab. Investig. 2020, 100, 863-873. [CrossRef] [PubMed]

148. Blessing, A.M.; Santiago-O’Farrill, J.M.; Mao, W.; Pang, L.; Ning, J.; Pak, D.; Bollu, L.R.; Rask, P.; Iles, L.; Yang, H.; et al. Elimination of dormant, autophagic ovarian cancer cells and xenografts through enhanced sensitivity to anaplastic lymphoma kinase inhibition. Cancer 2020, 126, 3579-3592. [CrossRef] [PubMed]

149. Mauthe, M.; Orhon, I.; Rocchi, C.; Zhou, X.; Luhr, M.; Hijlkema, K.J.; Coppes, R.P.; Engedal, N.; Mari, M.; Reggiori, F. Chloroquine inhibits autophagic flux by decreasing autophagosome-lysosome fusion. Autophagy 2018, 14, 1435-1455. [CrossRef]

150. Hu, T.; Li, P.; Luo, Z.; Chen, X.; Zhang, J.; Wang, C.; Chen, P.; Dong, Z. Chloroquine inhibits hepatocellular carcinoma cell growth in vitro and in vivo. Oncol Rep 2016, 35, 43-49. [CrossRef]

151. Zheng, Y.; Zhao, Y.L.; Deng, X.; Yang, S.; Mao, Y.; Li, Z.; Jiang, P.; Zhao, X.; Wei, Y. Chloroquine inhibits colon cancer cell growth in vitro and tumor growth in vivo via induction of apoptosis. Cancer Investig. 2009, 27, 286-292. [CrossRef] [PubMed]

152. Verbaanderd, C.; Maes, H.; Schaaf, M.B.; Sukhatme, V.P.; Pantziarka, P.; Sukhatme, V.; Agostinis, P.; Bouche, G. Repurposing Drugs in Oncology (ReDO)-chloroquine and hydroxychloroquine as anti-cancer agents. Ecancermedicalscience 2017, $11,781$. [CrossRef] [PubMed]

153. Dikic, I.; Elazar, Z. Mechanism and medical implications of mammalian autophagy. Nat. Rev. Mol. Cell. Biol. 2018, 19, 349-364. [CrossRef] [PubMed]

154. Rangwala, R.; Leone, R.; Chang, Y.C.; Fecher, L.A.; Schuchter, L.M.; Kramer, A.; Tan, K.S.; Heitjan, D.F.; Rodgers, G.; Gallagher, M.; et al. Phase I trial of hydroxychloroquine with dose-intense temozolomide in patients with advanced solid tumors and melanoma. Autophagy 2014, 10, 1369-1379. [CrossRef]

155. Vogl, D.T.; Stadtmauer, E.A.; Tan, K.S.; Heitjan, D.F.; Davis, L.E.; Pontiggia, L.; Rangwala, R.; Piao, S.; Chang, Y.C.; Scott, E.C.; et al. Combined autophagy and proteasome inhibition: a phase 1 trial of hydroxychloroquine and bortezomib in patients with relapsed/refractory myeloma. Autophagy 2014, 10, 1380-1390. [CrossRef] [PubMed]

156. Boone, B.A.; Bahary, N.; Zureikat, A.H.; Moser, A.J.; Normolle, D.P.; Wu, W.C.; Singhi, A.D.; Bao, P.; Bartlett, D.L.; Liotta, L.A.; et al. Safety and Biologic Response of Pre-operative Autophagy Inhibition in Combination with Gemcitabine in Patients with Pancreatic Adenocarcinoma. Ann. Surg. Oncol. 2015, 22, 4402-4410. [CrossRef]

157. Maes, H.; Kuchnio, A.; Peric, A.; Moens, S.; Nys, K.; De Bock, K.; Quaegebeur, A.; Schoors, S.; Georgiadou, M.; Wouters, J.; et al. Tumor vessel normalization by chloroquine independent of autophagy. Cancer Cell 2014, 26, 190-206. [CrossRef] [PubMed]

158. Pellegrini, P.; Strambi, A.; Zipoli, C.; Hägg-Olofsson, M.; Buoncervello, M.; Linder, S.; De Milito, A. Acidic extracellular pH neutralizes the autophagy-inhibiting activity of chloroquine: Implications for cancer therapies. Autophagy 2014, 10, 562-571. [CrossRef] [PubMed]

159. Maycotte, P.; Gearheart, C.M.; Barnard, R.; Aryal, S.; Mulcahy Levy, J.M.; Fosmire, S.P.; Hansen, R.J.; Morgan, M.J.; Porter, C.C.; Gustafson, D.L.; et al. STAT3-mediated autophagy dependence identifies subtypes of breast cancer where autophagy inhibition can be efficacious. Cancer Res. 2014, 74, 2579-2590. [CrossRef] [PubMed]

160. Tang, F.; Hu, P.; Yang, Z.; Xue, C.; Gong, J.; Sun, S.; Shi, L.; Zhang, S.; Li, Z.; Yang, C.; et al. SBI0206965, a novel inhibitor of Ulk1, suppresses non-small cell lung cancer cell growth by modulating both autophagy and apoptosis pathways. Oncol. Rep. 2017, 37, 3449-3458. [CrossRef] [PubMed]

161. Ronan, B.; Flamand, O.; Vescovi, L.; Dureuil, C.; Durand, L.; Fassy, F.; Bachelot, M.F.; Lamberton, A.; Mathieu, M.; Bertrand, T.; et al. A highly potent and selective Vps34 inhibitor alters vesicle trafficking and autophagy. Nat. Chem. Biol. 2014, 10, 1013-1019. [CrossRef]

162. Dyczynski, M.; Yu, Y.; Otrocka, M.; Parpal, S.; Braga, T.; Henley, A.B.; Zazzi, H.; Lerner, M.; Wennerberg, K.; Viklund, J.; et al. Targeting autophagy by small molecule inhibitors of vacuolar protein sorting 34 (Vps34) improves the sensitivity of breast cancer cells to Sunitinib. Cancer Lett. 2018, 435, 32-43. [CrossRef]

163. Kurdi, A.; Cleenewerck, M.; Vangestel, C.; Lyssens, S.; Declercq, W.; Timmermans, J.P.; Stroobants, S.; Augustyns, K.; De Meyer, G.R.Y.; Van Der Veken, P.; et al. ATG4B inhibitors with a benzotropolone core structure block autophagy and augment efficiency of chemotherapy in mice. Biochem. Pharmacol. 2017, 138, 150-162. [CrossRef] [PubMed]

164. Akin, D.; Wang, S.K.; Habibzadegah-Tari, P.; Law, B.; Ostrov, D.; Li, M.; Yin, X.M.; Kim, J.S.; Horenstein, N.; Dunn, W.A. A novel ATG4B antagonist inhibits autophagy and has a negative impact on osteosarcoma tumors. Autophagy 2014, 10, $2021-2035$. [CrossRef] [PubMed]

165. Fu, Y.; Hong, L.; Xu, J.; Zhong, G.; Gu, Q.; Guan, Y.; Zheng, X.; Dai, Q.; Luo, X.; Liu, C.; et al. Discovery of a small molecule targeting autophagy via ATG4B inhibition and cell death of colorectal cancer cells in vitro and in vivo. Autophagy 2019, 15, 295-311. [CrossRef] [PubMed]

166. Tian, T.; Li, X.; Zhang, J. mTOR Signaling in Cancer and mTOR Inhibitors in Solid Tumor Targeting Therapy. Int. J. Mol. Sci. 2019, 20, 755. [CrossRef]

167. Law, B.K. Rapamycin: An anti-cancer immunosuppressant? Crit. Rev. Oncol. Hematol. 2005, 56, 47-60. [CrossRef] [PubMed] 
168. Hsieh, F.S.; Chen, Y.L.; Hung, M.H.; Chu, P.Y.; Tsai, M.H.; Chen, L.J.; Hsiao, Y.J.; Shih, C.T.; Chang, M.J.; Chao, T.I.; et al. Palbociclib induces activation of AMPK and inhibits hepatocellular carcinoma in a CDK4/6-independent manner. Mol. Oncol. 2017, 11, 1035-1049. [CrossRef] [PubMed]

169. Ohashi, Y.; Tremel, S.; Williams, R.L. VPS34 complexes from a structural perspective. J. Lipid. Res. 2019, 60, 229-241. [CrossRef]

170. Pavlinov, I.; Salkovski, M.; Aldrich, L.N. Beclin 1-ATG14L Protein-Protein Interaction Inhibitor Selectively Inhibits Autophagy through Disruption of VPS34 Complex I. J. Am. Chem. Soc. 2020, 142, 8174-8182. [CrossRef]

171. Xia, H.; Green, D.R.; Zou, W. Autophagy in tumour immunity and therapy. Nat. Rev. Cancer 2021, 21, 281-297. [CrossRef] [PubMed]

172. Bustos, S.O.; Antunes, F.; Rangel, M.C.; Chammas, R. Emerging Autophagy Functions Shape the Tumor Microenvironment and Play a Role in Cancer Progression - Implications for Cancer Therapy. Front Oncol. 2020, 10, 606436. [CrossRef] [PubMed]

173. Towers, C.G.; Fitzwalter, B.E.; Regan, D.; Goodspeed, A.; Morgan, M.J.; Liu, C.W.; Gustafson, D.L.; Thorburn, A. Cancer Cells Upregulate NRF2 Signaling to Adapt to Autophagy Inhibition. Dev. Cell. 2019, 50, 690-703. [CrossRef] [PubMed]

174. Kerins, M.J.; Liu, P.; Tian, W.; Mannheim, W.; Zhang, D.D.; Ooi, A. Genome-Wide CRISPR Screen Reveals Autophagy Disruption as the Convergence Mechanism That Regulates the NRF2 Transcription Factor. Mol. Cell. Biol. 2019, 39. [CrossRef] [PubMed]

175. Meade, R.M.; Fairlie, D.P.; Mason, J.M. Alpha-synuclein structure and Parkinson's disease - lessons and emerging principles. Mol. Neurodegener. 2019, 14, 29. [CrossRef] [PubMed]

176. Nalls, M.A.; Blauwendraat, C.; Vallerga, C.L.; Heilbron, K.; Bandres-Ciga, S.; Chang, D.; Tan, M.; Kia, D.A.; Noyce, A.J.; Xue, A.; et al. Identification of novel risk loci, causal insights, and heritable risk for Parkinson's disease: a meta-analysis of genome-wide association studies. Lancet. Neurol. 2019, 18, 1091-1102. [CrossRef]

177. Chang, D.; Nalls, M.A.; Hallgrímsdóttir, I.B.; Hunkapiller, J.; van der Brug, M.; Cai, F.; Kerchner, G.A.; Ayalon, G.; Bingol, B.; Sheng, M.; et al. A meta-analysis of genome-wide association studies identifies 17 new Parkinson's disease risk loci. Nat. Genet. 2017, 49, 1511-1516. [CrossRef]

178. Vogiatzi, T.; Xilouri, M.; Vekrellis, K.; Stefanis, L. Wild type alpha-synuclein is degraded by chaperone-mediated autophagy and macroautophagy in neuronal cells. J. Biol. Chem. 2008, 283, 23542-23556. [CrossRef] [PubMed]

179. Xilouri, M.; Brekk, O.R.; Landeck, N.; Pitychoutis, P.M.; Papasilekas, T.; Papadopoulou-Daifoti, Z.; Kirik, D.; Stefanis, L. Boosting chaperone-mediated autophagy in vivo mitigates $\alpha$-synuclein-induced neurodegeneration. Brain 2013, 136, 2130-2146. [CrossRef]

180. Cuervo, A.M.; Stefanis, L.; Fredenburg, R.; Lansbury, P.T.; Sulzer, D. Impaired degradation of mutant alpha-synuclein by chaperone-mediated autophagy. Science 2004, 305, 1292-1295. [CrossRef] [PubMed]

181. Xilouri, M.; Vogiatzi, T.; Vekrellis, K.; Park, D.; Stefanis, L. Abberant alpha-synuclein confers toxicity to neurons in part through inhibition of chaperone-mediated autophagy. PLoS ONE 2009, 4, e5515. [CrossRef] [PubMed]

182. Alvarez-Erviti, L.; Rodriguez-Oroz, M.C.; Cooper, J.M.; Caballero, C.; Ferrer, I.; Obeso, J.A.; Schapira, A.H. Chaperone-mediated autophagy markers in Parkinson disease brains. Arch. Neurol. 2010, 67, 1464-1472. [CrossRef] [PubMed]

183. Wu, G.; Wang, X.; Feng, X.; Zhang, A.; Li, J.; Gu, K.; Huang, J.; Pang, S.; Dong, H.; Gao, H.; et al. Altered expression of autophagic genes in the peripheral leukocytes of patients with sporadic Parkinson's disease. Brain Res. 2011, 1394, 105-111. [CrossRef] [PubMed]

184. Murphy, K.E.; Gysbers, A.M.; Abbott, S.K.; Spiro, A.S.; Furuta, A.; Cooper, A.; Garner, B.; Kabuta, T.; Halliday, G.M. Lysosomalassociated membrane protein 2 isoforms are differentially affected in early Parkinson's disease. Mov. Disord. 2015, 30, 1639-1647. [CrossRef]

185. Kabuta, T.; Furuta, A.; Aoki, S.; Furuta, K.; Wada, K. Aberrant interaction between Parkinson disease-associated mutant UCH-L1 and the lysosomal receptor for chaperone-mediated autophagy. J. Biol. Chem. 2008, 283, 23731-23738. [CrossRef] [PubMed]

186. Choi, I.; Zhang, Y.; Seegobin, S.P.; Pruvost, M.; Wang, Q.; Purtell, K.; Zhang, B.; Yue, Z. Microglia clear neuron-released $\alpha$-synuclein via selective autophagy and prevent neurodegeneration. Nat. Commun. 2020, 11, 1386. [CrossRef] [PubMed]

187. Winslow, A.R.; Chen, C.W.; Corrochano, S.; Acevedo-Arozena, A.; Gordon, D.E.; Peden, A.A.; Lichtenberg, M.; Menzies, F.M.; Ravikumar, B.; Imarisio, S.; et al. $\alpha$-Synuclein impairs macroautophagy: Implications for Parkinson's disease. J. Cell. Biol. 2010, 190, 1023-1037. [CrossRef]

188. Yan, J.Q.; Yuan, Y.H.; Gao, Y.N.; Huang, J.Y.; Ma, K.L.; Gao, Y.; Zhang, W.Q.; Guo, X.F.; Chen, N.H. Overexpression of human E46K mutant $\alpha$-synuclein impairs macroautophagy via inactivation of JNK1-Bcl-2 pathway. Mol. Neurobiol. 2014, 50, 685-701. [CrossRef]

189. Sarkar, S.; Olsen, A.L.; Sygnecka, K.; Lohr, K.M.; Feany, M.B. $\alpha$-synuclein impairs autophagosome maturation through abnormal actin stabilization. PLoS Genet. 2021, 17, e1009359. [CrossRef]

190. Tanik, S.A.; Schultheiss, C.E.; Volpicelli-Daley, L.A.; Brunden, K.R.; Lee, V.M. Lewy body-like $\alpha$-synuclein aggregates resist degradation and impair macroautophagy. J. Biol. Chem. 2013, 288, 15194-15210. [CrossRef] [PubMed]

191. Danzer, K.M.; Kranich, L.R.; Ruf, W.P.; Cagsal-Getkin, O.; Winslow, A.R.; Zhu, L.; Vanderburg, C.R.; McLean, P.J. Exosomal cell-to-cell transmission of alpha synuclein oligomers. Mol. Neurodegener. 2012, 7, 42. [CrossRef]

192. Fussi, N.; Höllerhage, M.; Chakroun, T.; Nykänen, N.P.; Rösler, T.W.; Koeglsperger, T.; Wurst, W.; Behrends, C.; Höglinger, G.U. Exosomal secretion of $\alpha$-synuclein as protective mechanism after upstream blockage of macroautophagy. Cell. Death Dis. 2018, 9, 757. [CrossRef] 
193. Minakaki, G.; Menges, S.; Kittel, A.; Emmanouilidou, E.; Schaeffner, I.; Barkovits, K.; Bergmann, A.; Rockenstein, E.; Adame, A.; Marxreiter, F.; et al. Autophagy inhibition promotes SNCA/alpha-synuclein release and transfer via extracellular vesicles with a hybrid autophagosome-exosome-like phenotype. Autophagy 2018, 14, 98-119. [CrossRef] [PubMed]

194. Poehler, A.M.; Xiang, W.; Spitzer, P.; May, V.E.; Meixner, H.; Rockenstein, E.; Chutna, O.; Outeiro, T.F.; Winkler, J.; Masliah, E.; et al. Autophagy modulates SNCA/ $\alpha$-synuclein release, thereby generating a hostile microenvironment. Autophagy 2014, 10, 2171-2192. [CrossRef]

195. Angot, E.; Steiner, J.A.; Lema Tomé, C.M.; Ekström, P.; Mattsson, B.; Björklund, A.; Brundin, P. Alpha-synuclein cell-to-cell transfer and seeding in grafted dopaminergic neurons in vivo. PLoS ONE 2012, 7, e39465. [CrossRef] [PubMed]

196. Tolosa, E.; Vila, M.; Klein, C.; Rascol, O. LRRK2 in Parkinson disease: Challenges of clinical trials. Nat. Rev. Neurol. 2020, 16, 97-107. [CrossRef] [PubMed]

197. Orenstein, S.J.; Kuo, S.H.; Tasset, I.; Arias, E.; Koga, H.; Fernandez-Carasa, I.; Cortes, E.; Honig, L.S.; Dauer, W.; Consiglio, A.; et al. Interplay of LRRK2 with chaperone-mediated autophagy. Nat. Neurosci. 2013, 16, 394-406. [CrossRef]

198. Ho, P.W.; Leung, C.T.; Liu, H.; Pang, S.Y.; Lam, C.S.; Xian, J.; Li, L.; Kung, M.H.; Ramsden, D.B.; Ho, S.L. Age-dependent accumulation of oligomeric SNCA / $\alpha$-synuclein from impaired degradation in mutant LRRK2 knockin mouse model of Parkinson disease: Role for therapeutic activation of chaperone-mediated autophagy (CMA). Autophagy 2020, 16, 347-370. [CrossRef] [PubMed]

199. Manzoni, C.; Mamais, A.; Roosen, D.A.; Dihanich, S.; Soutar, M.P.; Plun-Favreau, H.; Bandopadhyay, R.; Hardy, J.; Tooze, S.A.; Cookson, M.R.; et al. mTOR independent regulation of macroautophagy by Leucine Rich Repeat Kinase 2 via Beclin-1. Sci. Rep. 2016, 6, 35106. [CrossRef] [PubMed]

200. Obergasteiger, J.; Frapporti, G.; Lamonaca, G.; Pizzi, S.; Picard, A.; Lavdas, A.A.; Pischedda, F.; Piccoli, G.; Hilfiker, S.; Lobbestael, E.; et al. Kinase inhibition of G2019S-LRRK2 enhances autolysosome formation and function to reduce endogenous alpha-synuclein intracellular inclusions. Cell. Death Discov. 2020, 6, 45. [CrossRef] [PubMed]

201. Bravo-San Pedro, J.M.; Niso-Santano, M.; Gómez-Sánchez, R.; Pizarro-Estrella, E.; Aiastui-Pujana, A.; Gorostidi, A.; Climent, V.; López de Maturana, R.; Sanchez-Pernaute, R.; López de Munain, A.; et al. The LRRK2 G2019S mutant exacerbates basal autophagy through activation of the MEK/ERK pathway. Cell. Mol. Life Sci. 2013, 70, 121-136. [CrossRef] [PubMed]

202. Giaime, E.; Tong, Y.; Wagner, L.K.; Yuan, Y.; Huang, G.; Shen, J. Age-Dependent Dopaminergic Neurodegeneration and Impairment of the Autophagy-Lysosomal Pathway in LRRK-Deficient Mice. Neuron 2017, 96, 796-807. [CrossRef] [PubMed]

203. Malpartida, A.B.; Williamson, M.; Narendra, D.P.; Wade-Martins, R.; Ryan, B.J. Mitochondrial Dysfunction and Mitophagy in Parkinson's Disease: From Mechanism to Therapy. Trends Biochem. Sci. 2021, 46, 329-343. [CrossRef] [PubMed]

204. Moore, D.J.; West, A.B.; Dawson, V.L.; Dawson, T.M. Molecular pathophysiology of Parkinson's disease. Annu. Rev. Neurosci. 2005, 28, 57-87. [CrossRef] [PubMed]

205. Geisler, S.; Holmström, K.M.; Treis, A.; Skujat, D.; Weber, S.S.; Fiesel, F.C.; Kahle, P.J.; Springer, W. The PINK1/Parkin-mediated mitophagy is compromised by PD-associated mutations. Autophagy 2010, 6, 871-878. [CrossRef] [PubMed]

206. Ganjam, G.K.; Bolte, K.; Matschke, L.A.; Neitemeier, S.; Dolga, A.M.; Höllerhage, M.; Höglinger, G.U.; Adamczyk, A.; Decher, N.; Oertel, W.H.; et al. Mitochondrial damage by $\alpha$-synuclein causes cell death in human dopaminergic neurons. Cell Death Dis. 2019, 10, 865. [CrossRef] [PubMed]

207. Di Maio, R.; Barrett, P.J.; Hoffman, E.K.; Barrett, C.W.; Zharikov, A.; Borah, A.; Hu, X.; McCoy, J.; Chu, C.T.; Burton, E.A.; et al. $\alpha$-Synuclein binds to TOM20 and inhibits mitochondrial protein import in Parkinson's disease. Sci. Transl. Med. 2016, 8, 342-378. [CrossRef] [PubMed]

208. Little, D.; Luft, C.; Mosaku, O.; Lorvellec, M.; Yao, Z.; Paillusson, S.; Kriston-Vizi, J.; Gandhi, S.; Abramov, A.Y.; Ketteler, R.; et al. A single cell high content assay detects mitochondrial dysfunction in iPSC-derived neurons with mutations in SNCA. Sci. Rep. 2018, 8, 9033. [CrossRef] [PubMed]

209. Park, J.H.; Burgess, J.D.; Faroqi, A.H.; DeMeo, N.N.; Fiesel, F.C.; Springer, W.; Delenclos, M.; McLean, P.J. Alpha-synucleininduced mitochondrial dysfunction is mediated via a sirtuin 3-dependent pathway. Mol. Neurodegener. 2020, 15, 5. [CrossRef] [PubMed]

210. Sampaio-Marques, B.; Felgueiras, C.; Silva, A.; Rodrigues, M.; Tenreiro, S.; Franssens, V.; Reichert, A.S.; Outeiro, T.F.; Winderickx, J.; Ludovico, P. SNCA ( $\alpha$-synuclein)-induced toxicity in yeast cells is dependent on sirtuin 2 (Sir2)-mediated mitophagy. Autophagy 2012, 8, 1494-1509. [CrossRef]

211. Hsieh, C.H.; Shaltouki, A.; Gonzalez, A.E.; Bettencourt da Cruz, A.; Burbulla, L.F.; St Lawrence, E.; Schüle, B.; Krainc, D.; Palmer, T.D.; Wang, X. Functional Impairment in Miro Degradation and Mitophagy Is a Shared Feature in Familial and Sporadic Parkinson's Disease. Cell Stem. Cell. 2016, 19, 709-724. [CrossRef]

212. Bonello, F.; Hassoun, S.M.; Mouton-Liger, F.; Shin, Y.S.; Muscat, A.; Tesson, C.; Lesage, S.; Beart, P.M.; Brice, A.; Krupp, J.; et al. LRRK2 impairs PINK1/Parkin-dependent mitophagy via its kinase activity: Pathologic insights into Parkinson's disease. Hum. Mol. Genet. 2019, 28, 1645-1660. [CrossRef] [PubMed]

213. Wauters, F.; Cornelissen, T.; Imberechts, D.; Martin, S.; Koentjoro, B.; Sue, C.; Vangheluwe, P.; Vandenberghe, W. Mutations impair depolarization-induced mitophagy through inhibition of mitochondrial accumulation of RAB10. Autophagy 2020, 16, $203-222$. [CrossRef] [PubMed] 
214. Du, T.T.; Wang, L.; Duan, C.L.; Lu, L.L.; Zhang, J.L.; Gao, G.; Qiu, X.B.; Wang, X.M.; Yang, H. GBA deficiency promotes SNCA/ $\alpha$ synuclein accumulation through autophagic inhibition by inactivated PPP2A. Autophagy 2015, 11, 1803-1820. [CrossRef] [PubMed]

215. Li, H.; Ham, A.; Ma, T.C.; Kuo, S.H.; Kanter, E.; Kim, D.; Ko, H.S.; Quan, Y.; Sardi, S.P.; Li, A.; et al. Mitochondrial dysfunction and mitophagy defect triggered by heterozygous GBA mutations. Autophagy 2019, 15, 113-130. [CrossRef]

216. Lesage, S.; Drouet, V.; Majounie, E.; Deramecourt, V.; Jacoupy, M.; Nicolas, A.; Cormier-Dequaire, F.; Hassoun, S.M.; Pujol, C.; Ciura, S.; et al. Loss of VPS13C Function in Autosomal-Recessive Parkinsonism Causes Mitochondrial Dysfunction and Increases PINK1/Parkin-Dependent Mitophagy. Am. J. Hum. Genet. 2016, 98, 500-513. [CrossRef] [PubMed]

217. Zavodszky, E.; Seaman, M.N.; Moreau, K.; Jimenez-Sanchez, M.; Breusegem, S.Y.; Harbour, M.E.; Rubinsztein, D.C. Mutation in VPS35 associated with Parkinson's disease impairs WASH complex association and inhibits autophagy. Nat. Commun. 2014, 5, 3828. [CrossRef] [PubMed]

218. Tang, F.L.; Erion, J.R.; Tian, Y.; Liu, W.; Yin, D.M.; Ye, J.; Tang, B.; Mei, L.; Xiong, W.C. VPS35 in Dopamine Neurons Is Required for Endosome-to-Golgi Retrieval of Lamp2a, a Receptor of Chaperone-Mediated Autophagy That Is Critical for $\alpha$-Synuclein Degradation and Prevention of Pathogenesis of Parkinson's Disease. J. Neurosci. 2015, 35, 10613-10628. [CrossRef]

219. Ma, K.Y.; Fokkens, M.R.; Reggiori, F.; Mari, M.; Verbeek, D.S. Parkinson's disease-associated VPS35 mutant reduces mitochondrial membrane potential and impairs PINK1/Parkin-mediated mitophagy. Transl. Neurodegener. 2021, 10, 19. [CrossRef] [PubMed]

220. Nash, Y.; Schmukler, E.; Trudler, D.; Pinkas-Kramarski, R.; Frenkel, D. DJ-1 deficiency impairs autophagy and reduces alphasynuclein phagocytosis by microglia. J. Neurochem. 2017, 143, 584-594. [CrossRef] [PubMed]

221. Xu, C.Y.; Kang, W.Y.; Chen, Y.M.; Jiang, T.F.; Zhang, J.; Zhang, L.N.; Ding, J.Q.; Liu, J.; Chen, S.D. DJ-1 Inhibits $\alpha-S y n u c l e i n$ Aggregation by Regulating Chaperone-Mediated Autophagy. Front Aging Neurosci. 2017, 9, 308. [CrossRef] [PubMed]

222. Hao, L.Y.; Giasson, B.I.; Bonini, N.M. DJ-1 is critical for mitochondrial function and rescues PINK1 loss of function. Proc. Natl. Acad. Sci. USA 2010, 107, 9747-9752. [CrossRef] [PubMed]

223. Ivatt, R.M.; Sanchez-Martinez, A.; Godena, V.K.; Brown, S.; Ziviani, E.; Whitworth, A.J. Genome-wide RNAi screen identifies the Parkinson disease GWAS risk locus SREBF1 as a regulator of mitophagy. Proc. Natl. Acad. Sci. USA 2014, 111, 8494-8499. [CrossRef] [PubMed]

224. Burchell, V.S.; Nelson, D.E.; Sanchez-Martinez, A.; Delgado-Camprubi, M.; Ivatt, R.M.; Pogson, J.H.; Randle, S.J.; Wray, S.; Lewis, P.A.; Houlden, H.; et al. The Parkinson's disease-linked proteins Fbxo7 and Parkin interact to mediate mitophagy. Nat. Neurosci. 2013, 16, 1257-1265. [CrossRef]

225. Zhou, Z.D.; Xie, S.P.; Sathiyamoorthy, S.; Saw, W.T.; Sing, T.Y.; Ng, S.H.; Chua, H.P.; Tang, A.M.; Shaffra, F.; Li, Z.; et al. F-box protein 7 mutations promote protein aggregation in mitochondria and inhibit mitophagy. Hum. Mol. Genet. 2015, 24, 6314-6330. [CrossRef] [PubMed]

226. Jinn, S.; Drolet, R.E.; Cramer, P.E.; Wong, A.H.; Toolan, D.M.; Gretzula, C.A.; Voleti, B.; Vassileva, G.; Disa, J.; Tadin-Strapps, M.; et al. TMEM175 deficiency impairs lysosomal and mitochondrial function and increases $\alpha$-synuclein aggregation. Proc. Natl. Acad. Sci. USA 2017, 114, 2389-2394. [CrossRef]

227. Jinn, S.; Blauwendraat, C.; Toolan, D.; Gretzula, C.A.; Drolet, R.E.; Smith, S.; Nalls, M.A.; Marcus, J.; Singleton, A.B.; Stone, D.J. Functionalization of the TMEM175 p.M393T variant as a risk factor for Parkinson disease. Hum. Mol. Genet. 2019, 28, 3244-3254. [CrossRef] [PubMed]

228. Meng, H.; Yamashita, C.; Shiba-Fukushima, K.; Inoshita, T.; Funayama, M.; Sato, S.; Hatta, T.; Natsume, T.; Umitsu, M.; Takagi, J.; et al. Loss of Parkinson's disease-associated protein $\mathrm{CHCHD} 2$ affects mitochondrial crista structure and destabilizes cytochrome c. Nat. Commun. 2017, 8, 15500. [CrossRef]

229. Grünewald, A.; Arns, B.; Seibler, P.; Rakovic, A.; Münchau, A.; Ramirez, A.; Sue, C.M.; Klein, C. ATP13A2 mutations impair mitochondrial function in fibroblasts from patients with Kufor-Rakeb syndrome. Neurobiol. Aging 2012, 33, 1841-1843. [CrossRef]

230. Ramonet, D.; Podhajska, A.; Stafa, K.; Sonnay, S.; Trancikova, A.; Tsika, E.; Pletnikova, O.; Troncoso, J.C.; Glauser, L.; Moore, D.J. PARK9-associated ATP13A2 localizes to intracellular acidic vesicles and regulates cation homeostasis and neuronal integrity. Hum. Mol. Genet. 2012, 21, 1725-1743. [CrossRef]

231. Hunn, B.H.M.; Vingill, S.; Threlfell, S.; Alegre-Abarrategui, J.; Magdelyns, M.; Deltheil, T.; Bengoa-Vergniory, N.; Oliver, P.L.; Cioroch, M.; Doig, N.M.; et al. Impairment of Macroautophagy in Dopamine Neurons Has Opposing Effects on Parkinsonian Pathology and Behavior. Cell Rep. 2019, 29, 920-931. [CrossRef] [PubMed]

232. Rosenberg, R.N.; Lambracht-Washington, D.; Yu, G.; Xia, W. Genomics of Alzheimer Disease: A Review. JAMA Neurol. 2016, 73, 867-874. [CrossRef]

233. Pickford, F.; Masliah, E.; Britschgi, M.; Lucin, K.; Narasimhan, R.; Jaeger, P.A.; Small, S.; Spencer, B.; Rockenstein, E.; Levine, B.; et al. The autophagy-related protein beclin 1 shows reduced expression in early Alzheimer disease and regulates amyloid beta accumulation in mice. J. Clin. Investig. 2008, 118, 2190-2199. [CrossRef]

234. Manczak, M.; Kandimalla, R.; Yin, X.; Reddy, P.H. Hippocampal mutant APP and amyloid beta-induced cognitive decline, dendritic spine loss, defective autophagy, mitophagy and mitochondrial abnormalities in a mouse model of Alzheimer's disease. Hum. Mol. Genet. 2018, 27, 1332-1342. [CrossRef]

235. Yu, W.H.; Cuervo, A.M.; Kumar, A.; Peterhoff, C.M.; Schmidt, S.D.; Lee, J.H.; Mohan, P.S.; Mercken, M.; Farmery, M.R.; Tjernberg, L.O.; et al. Macroautophagy-a novel Beta-amyloid peptide-generating pathway activated in Alzheimer's disease. J. Cell Biol. 2005, 171, 87-98. [CrossRef] [PubMed] 
236. Sanchez-Varo, R.; Trujillo-Estrada, L.; Sanchez-Mejias, E.; Torres, M.; Baglietto-Vargas, D.; Moreno-Gonzalez, I.; De Castro, V.; Jimenez, S.; Ruano, D.; Vizuete, M.; et al. Abnormal accumulation of autophagic vesicles correlates with axonal and synaptic pathology in young Alzheimer's mice hippocampus. Acta Neuropathol. 2012, 123, 53-70. [CrossRef] [PubMed]

237. Lee, J.H.; Yu, W.H.; Kumar, A.; Lee, S.; Mohan, P.S.; Peterhoff, C.M.; Wolfe, D.M.; Martinez-Vicente, M.; Massey, A.C.; Sovak, G.; et al. Lysosomal proteolysis and autophagy require presenilin 1 and are disrupted by Alzheimer-related PS1 mutations. Cell 2010, 141, 1146-1158. [CrossRef]

238. Coffey, E.E.; Beckel, J.M.; Laties, A.M.; Mitchell, C.H. Lysosomal alkalization and dysfunction in human fibroblasts with the Alzheimer's disease-linked presenilin 1 A246E mutation can be reversed with cAMP. Neuroscience 2014, 263, 111-124. [CrossRef] [PubMed]

239. Moreau, K.; Fleming, A.; Imarisio, S.; Lopez Ramirez, A.; Mercer, J.L.; Jimenez-Sanchez, M.; Bento, C.F.; Puri, C.; Zavodszky, E.; Siddiqi, F.; et al. PICALM modulates autophagy activity and tau accumulation. Nat. Commun. 2014, 5, 4998. [CrossRef]

240. Ando, K.; Tomimura, K.; Sazdovitch, V.; Suain, V.; Yilmaz, Z.; Authelet, M.; Ndjim, M.; Vergara, C.; Belkouch, M.; Potier, M.C.; et al. Level of PICALM, a key component of clathrin-mediated endocytosis, is correlated with levels of phosphotau and autophagy-related proteins and is associated with tau inclusions in AD, PSP and Pick disease. Neurobiol. Dis. 2016, 94, 32-43. [CrossRef]

241. Ando, K.; De Decker, R.; Vergara, C.; Yilmaz, Z.; Mansour, S.; Suain, V.; Sleegers, K.; de Fisenne, M.A.; Houben, S.; Potier, M.C.; et al. Picalm reduction exacerbates tau pathology in a murine tauopathy model. Acta Neuropathol. 2020, 139, 773-789. [CrossRef]

242. Lipinski, M.M.; Zheng, B.; Lu, T.; Yan, Z.; Py, B.F.; Ng, A.; Xavier, R.J.; Li, C.; Yankner, B.A.; Scherzer, C.R.; et al. Genome-wide analysis reveals mechanisms modulating autophagy in normal brain aging and in Alzheimer's disease. Proc. Natl. Acad. Sci. USA 2010, 107, 14164-14169. [CrossRef] [PubMed]

243. Bordi, M.; Berg, M.J.; Mohan, P.S.; Peterhoff, C.M.; Alldred, M.J.; Che, S.; Ginsberg, S.D.; Nixon, R.A. Autophagy flux in CA1 neurons of Alzheimer hippocampus: Increased induction overburdens failing lysosomes to propel neuritic dystrophy. Autophagy 2016, 12, 2467-2483. [CrossRef] [PubMed]

244. Luo, R.; Su, L.Y.; Li, G.; Yang, J.; Liu, Q.; Yang, L.X.; Zhang, D.F.; Zhou, H.; Xu, M.; Fan, Y.; et al. Activation of PPARA-mediated autophagy reduces Alzheimer disease-like pathology and cognitive decline in a murine model. Autophagy 2020, 16, 52-69. [CrossRef] [PubMed]

245. Tong, B.C.; Wu, A.J.; Huang, A.S.; Dong, R.; Malampati, S.; Iyaswamy, A.; Krishnamoorthi, S.; Sreenivasmurthy, S.G.; Zhu, Z.; $\mathrm{Su}, \mathrm{C}$; ; et al. Lysosomal TPCN (two pore segment channel) inhibition ameliorates beta-amyloid pathology and mitigates memory impairment in Alzheimer disease. Autophagy 2021, 1-19. [CrossRef]

246. Zheng, X.; Lin, W.; Jiang, Y.; Lu, K.; Wei, W.; Huo, Q.; Cui, S.; Yang, X.; Li, M.; Xu, N.; et al. Electroacupuncture ameliorates beta-amyloid pathology and cognitive impairment in Alzheimer disease via a novel mechanism involving activation of TFEB (transcription factor EB). Autophagy 2021, 1-15. [CrossRef] [PubMed]

247. Chen, M.L.; Hong, C.G.; Yue, T.; Li, H.M.; Duan, R.; Hu, W.B.; Cao, J.; Wang, Z.X.; Chen, C.Y.; Hu, X.K.; et al. Inhibition of miR-331-3p and miR-9-5p ameliorates Alzheimer's disease by enhancing autophagy. Theranostics 2021, 11, 2395-2409. [CrossRef] [PubMed]

248. Nilsson, P.; Loganathan, K.; Sekiguchi, M.; Matsuba, Y.; Hui, K.; Tsubuki, S.; Tanaka, M.; Iwata, N.; Saito, T.; Saido, T.C. A $\beta$ secretion and plaque formation depend on autophagy. Cell Rep. 2013, 5, 61-69. [CrossRef] [PubMed]

249. Benito-Cuesta, I.; Ordóñez-Gutiérrez, L.; Wandosell, F. AMPK activation does not enhance autophagy in neurons in contrast to MTORC1 inhibition: Different impact on $\beta$-amyloid clearance. Autophagy 2021, 17, 656-671. [CrossRef]

250. Park, J.S.; Kim, D.H.; Yoon, S.Y. Regulation of amyloid precursor protein processing by its KFERQ motif. BMB Rep. 2016, 49, 337-342. [CrossRef] [PubMed]

251. Jiang, S.; Bhaskar, K. Degradation and Transmission of Tau by Autophagic-Endolysosomal Networks and Potential Therapeutic Targets for Tauopathy. Front Mol. Neurosci. 2020, 13, 586731. [CrossRef] [PubMed]

252. Caballero, B.; Wang, Y.; Diaz, A.; Tasset, I.; Juste, Y.R.; Stiller, B.; Mandelkow, E.M.; Mandelkow, E.; Cuervo, A.M. Interplay of pathogenic forms of human tau with different autophagic pathways. Aging Cell 2018, 17, e12692. [CrossRef] [PubMed]

253. Silva, M.C.; Nandi, G.A.; Tentarelli, S.; Gurrell, I.K.; Jamier, T.; Lucente, D.; Dickerson, B.C.; Brown, D.G.; Brandon, N.J.; Haggarty, S.J. Prolonged tau clearance and stress vulnerability rescue by pharmacological activation of autophagy in tauopathy neurons. Nat. Commun. 2020, 11, 3258. [CrossRef]

254. Bourdenx, M.; Martín-Segura, A.; Scrivo, A.; Rodriguez-Navarro, J.A.; Kaushik, S.; Tasset, I.; Diaz, A.; Storm, N.J.; Xin, Q.; Juste, Y.R.; et al. Chaperone-mediated autophagy prevents collapse of the neuronal metastable proteome. Cell 2021, 184, $2696-2714$. [CrossRef]

255. Chakravorty, A.; Jetto, C.T.; Manjithaya, R. Dysfunctional Mitochondria and Mitophagy as Drivers of Alzheimer's Disease Pathogenesis. Front Aging Neurosci. 2019, 11, 311. [CrossRef]

256. Fang, E.F.; Hou, Y.; Palikaras, K.; Adriaanse, B.A.; Kerr, J.S.; Yang, B.; Lautrup, S.; Hasan-Olive, M.M.; Caponio, D.; Dan, X.; et al. Mitophagy inhibits amyloid- $\beta$ and tau pathology and reverses cognitive deficits in models of Alzheimer's disease. Nat. Neurosci. 2019, 22, 401-412. [CrossRef]

257. Ye, X.; Sun, X.; Starovoytov, V.; Cai, Q. Parkin-mediated mitophagy in mutant hAPP neurons and Alzheimer's disease patient brains. Hum. Mol. Genet. 2015, 24, 2938-2951. [CrossRef] 
258. Martín-Maestro, P.; Gargini, R.; Perry, G.; Avila, J.; García-Escudero, V. PARK2 enhancement is able to compensate mitophagy alterations found in sporadic Alzheimer's disease. Hum. Mol. Genet. 2016, 25, 792-806. [CrossRef] [PubMed]

259. Cummins, N.; Tweedie, A.; Zuryn, S.; Bertran-Gonzalez, J.; Götz, J. Disease-associated tau impairs mitophagy by inhibiting Parkin translocation to mitochondria. EMBO J. 2019, 38. [CrossRef]

260. Hu, Y.; Li, X.C.; Wang, Z.H.; Luo, Y.; Zhang, X.; Liu, X.P.; Feng, Q.; Wang, Q.; Yue, Z.; Chen, Z.; et al. Tau accumulation impairs mitophagy via increasing mitochondrial membrane potential and reducing mitochondrial Parkin. Oncotarget 2016, 7, 17356-17368. [CrossRef]

261. Reddy, P.H.; Oliver, D.M. Amyloid Beta and Phosphorylated Tau-Induced Defective Autophagy and Mitophagy in Alzheimer's Disease. Cells 2019, 8, 488. [CrossRef] [PubMed]

262. Nopoulos, P.C. Huntington disease: a single-gene degenerative disorder of the striatum. Dialogues Clin. Neurosci. 2016, 18, 91-98.

263. Bjørkøy, G.; Lamark, T.; Brech, A.; Outzen, H.; Perander, M.; Overvatn, A.; Stenmark, H.; Johansen, T. p62/SQSTM1 forms protein aggregates degraded by autophagy and has a protective effect on huntingtin-induced cell death. J. Cell Biol. 2005, 171, 603-614. [CrossRef]

264. Shen, W.C.; Li, H.Y.; Chen, G.C.; Chern, Y.; Tu, P.H. Mutations in the ubiquitin-binding domain of OPTN/optineurin interfere with autophagy-mediated degradation of misfolded proteins by a dominant-negative mechanism. Autophagy 2015, 11, 685-700. [CrossRef]

265. Kurosawa, M.; Matsumoto, G.; Kino, Y.; Okuno, M.; Kurosawa-Yamada, M.; Washizu, C.; Taniguchi, H.; Nakaso, K.; Yanagawa, T.; Warabi, E.; et al. Depletion of p62 reduces nuclear inclusions and paradoxically ameliorates disease phenotypes in Huntington's model mice. Hum. Mol. Genet. 2015, 24, 1092-1105. [CrossRef] [PubMed]

266. Martin, D.D.; Ladha, S.; Ehrnhoefer, D.E.; Hayden, M.R. Autophagy in Huntington disease and huntingtin in autophagy. Trends Neurosci. 2015, 38, 26-35. [CrossRef] [PubMed]

267. Martinez-Vicente, M.; Talloczy, Z.; Wong, E.; Tang, G.; Koga, H.; Kaushik, S.; de Vries, R.; Arias, E.; Harris, S.; Sulzer, D.; et al. Cargo recognition failure is responsible for inefficient autophagy in Huntington's disease. Nat. Neurosci. 2010, 13, 567-576. [CrossRef] [PubMed]

268. Wold, M.S.; Lim, J.; Lachance, V.; Deng, Z.; Yue, Z. ULK1-mediated phosphorylation of ATG14 promotes autophagy and is impaired in Huntington's disease models. Mol. Neurodegener. 2016, 11, 76. [CrossRef] [PubMed]

269. Ravikumar, B.; Vacher, C.; Berger, Z.; Davies, J.E.; Luo, S.; Oroz, L.G.; Scaravilli, F.; Easton, D.F.; Duden, R.; O’Kane, C.J.; et al. Inhibition of mTOR induces autophagy and reduces toxicity of polyglutamine expansions in fly and mouse models of Huntington disease. Nat. Genet. 2004, 36, 585-595. [CrossRef] [PubMed]

270. Sarkar, S.; Ravikumar, B.; Floto, R.A.; Rubinsztein, D.C. Rapamycin and mTOR-independent autophagy inducers ameliorate toxicity of polyglutamine-expanded huntingtin and related proteinopathies. Cell Death Differ. 2009, 16, 46-56. [CrossRef]

271. Jiang, W.; Wei, W.; Gaertig, M.A.; Li, S.; Li, X.J. Therapeutic Effect of Berberine on Huntington's Disease Transgenic Mouse Model. PLoS ONE 2015, 10, e0134142. [CrossRef]

272. Feng, X.; Luo, S.; Lu, B. Conformation Polymorphism of Polyglutamine Proteins. Trends Biochem. Sci. 2018, 43, 424-435. [CrossRef]

273. Fu, Y.; Wu, P.; Pan, Y.; Sun, X.; Yang, H.; Difiglia, M.; Lu, B. A toxic mutant huntingtin species is resistant to selective autophagy. Nat Chem Biol 2017, 13, 1152-1154. [CrossRef]

274. Ochaba, J.; Lukacsovich, T.; Csikos, G.; Zheng, S.; Margulis, J.; Salazar, L.; Mao, K.; Lau, A.L.; Yeung, S.Y.; Humbert, S.; et al. Potential function for the Huntingtin protein as a scaffold for selective autophagy. Proc. Natl. Acad. Sci. USA 2014, 111, 16889-16894. [CrossRef] [PubMed]

275. Rui, Y.N.; Xu, Z.; Patel, B.; Chen, Z.; Chen, D.; Tito, A.; David, G.; Sun, Y.; Stimming, E.F.; Bellen, H.J.; et al. Huntingtin functions as a scaffold for selective macroautophagy. Nat. Cell Biol. 2015, 17, 262-275. [CrossRef] [PubMed]

276. Djajadikerta, A.; Keshri, S.; Pavel, M.; Prestil, R.; Ryan, L.; Rubinsztein, D.C. Autophagy Induction as a Therapeutic Strategy for Neurodegenerative Diseases. J. Mol. Biol. 2020, 432, 2799-2821. [CrossRef] [PubMed]

277. Ozcelik, S.; Fraser, G.; Castets, P.; Schaeffer, V.; Skachokova, Z.; Breu, K.; Clavaguera, F.; Sinnreich, M.; Kappos, L.; Goedert, M.; et al. Rapamycin attenuates the progression of tau pathology in P301S tau transgenic mice. PLoS ONE 2013, 8, e62459. [CrossRef] [PubMed]

278. Jiang, T.; Yu, J.T.; Zhu, X.C.; Zhang, Q.Q.; Cao, L.; Wang, H.F.; Tan, M.S.; Gao, Q.; Qin, H.; Zhang, Y.D.; et al. Temsirolimus attenuates tauopathy in vitro and in vivo by targeting tau hyperphosphorylation and autophagic clearance. Neuropharmacology 2014, 85, 121-130. [CrossRef] [PubMed]

279. Bai, X.; Wey, M.C.; Fernandez, E.; Hart, M.J.; Gelfond, J.; Bokov, A.F.; Rani, S.; Strong, R. Rapamycin improves motor function, reduces 4-hydroxynonenal adducted protein in brain, and attenuates synaptic injury in a mouse model of synucleinopathy. Pathobiol. Aging Age Relat. Dis. 2015, 5, 28743. [CrossRef] [PubMed]

280. Masini, D.; Bonito-Oliva, A.; Bertho, M.; Fisone, G. Inhibition of mTORC1 Signaling Reverts Cognitive and Affective Deficits in a Mouse Model of Parkinson's Disease. Front Neurol. 2018, 9, 208. [CrossRef] [PubMed]

281. He, Q.; Koprich, J.B.; Wang, Y.; Yu, W.B.; Xiao, B.G.; Brotchie, J.M.; Wang, J. Treatment with Trehalose Prevents Behavioral and Neurochemical Deficits Produced in an AAV alpha-Synuclein Rat Model of Parkinson's Disease. Mol. Neurobiol. 2016, 53, 2258-2268. [CrossRef] [PubMed]

282. Tanaka, M.; Machida, Y.; Niu, S.; Ikeda, T.; Jana, N.R.; Doi, H.; Kurosawa, M.; Nekooki, M.; Nukina, N. Trehalose alleviates polyglutamine-mediated pathology in a mouse model of Huntington disease. Nat. Med. 2004, 10, 148-154. [CrossRef] 
283. Pupyshev, A.B.; Tikhonova, M.A.; Akopyan, A.A.; Tenditnik, M.V.; Dubrovina, N.I.; Korolenko, T.A. Therapeutic activation of autophagy by combined treatment with rapamycin and trehalose in a mouse MPTP-induced model of Parkinson's disease. Pharmacol. Biochem. Behav. 2019, 177, 1-11. [CrossRef] [PubMed]

284. Siddiqi, F.H.; Menzies, F.M.; Lopez, A.; Stamatakou, E.; Karabiyik, C.; Ureshino, R.; Ricketts, T.; Jimenez-Sanchez, M.; Esteban, M.A.; Lai, L.; et al. Felodipine induces autophagy in mouse brains with pharmacokinetics amenable to repurposing. Nat. Commun. 2019, 10, 1817. [CrossRef] [PubMed]

285. Han, K.; Jia, N.; Zhong, Y.; Shang, X. S14G-humanin alleviates insulin resistance and increases autophagy in neurons of APP/PS1 transgenic mouse. J. Cell Biochem. 2018, 119, 3111-3117. [CrossRef]

286. Luengo, E.; Buendia, I.; Fernandez-Mendivil, C.; Trigo-Alonso, P.; Negredo, P.; Michalska, P.; Hernandez-Garcia, B.; SanchezRamos, C.; Bernal, J.A.; Ikezu, T.; et al. Pharmacological doses of melatonin impede cognitive decline in tau-related Alzheimer models, once tauopathy is initiated, by restoring the autophagic flux. J. Pineal Res. 2019, 67, e12578. [CrossRef] [PubMed]

287. Forlenza, O.V.; Radanovic, M.; Talib, L.L.; Gattaz, W.F. Clinical and biological effects of long-term lithium treatment in older adults with amnestic mild cognitive impairment: Randomised clinical trial. Br. J. Psych. 2019, 215, 668-674. [CrossRef] [PubMed]

288. Luchsinger, J.A.; Perez, T.; Chang, H.; Mehta, P.; Steffener, J.; Pradabhan, G.; Ichise, M.; Manly, J.; Devanand, D.P.; Bagiella, E. Metformin in Amnestic Mild Cognitive Impairment: Results of a Pilot Randomized Placebo Controlled Clinical Trial. J. Alzheimers. Dis. 2016, 51, 501-514. [CrossRef]

289. Pagan, F.; Hebron, M.; Valadez, E.H.; Torres-Yaghi, Y.; Huang, X.; Mills, R.R.; Wilmarth, B.M.; Howard, H.; Dunn, C.; Carlson, A.; et al. Nilotinib Effects in Parkinson's disease and Dementia with Lewy bodies. J. Parkinsons. Dis. 2016, 6, 503-517. [CrossRef] [PubMed]

290. Cen, X.; Chen, Y.; Xu, X.; Wu, R.; He, F.; Zhao, Q.; Sun, Q.; Yi, C.; Wu, J.; Najafov, A.; et al. Pharmacological targeting of MCL-1 promotes mitophagy and improves disease pathologies in an Alzheimer's disease mouse model. Nat. Commun. 2020, $11,5731$. [CrossRef]

291. Bauer, P.O.; Goswami, A.; Wong, H.K.; Okuno, M.; Kurosawa, M.; Yamada, M.; Miyazaki, H.; Matsumoto, G.; Kino, Y.; Nagai, Y.; et al. Harnessing chaperone-mediated autophagy for the selective degradation of mutant huntingtin protein. Nat. Biotechnol. 2010, 28, 256-263. [CrossRef] [PubMed]

292. Li, Z.; Wang, C.; Wang, Z.; Zhu, C.; Li, J.; Sha, T.; Ma, L.; Gao, C.; Yang, Y.; Sun, Y.; et al. Allele-selective lowering of mutant HTT protein by HTT-LC3 linker compounds. Nature 2019, 575, 203-209. [CrossRef]

293. Dou, J.; Su, P.; Xu, C.; Wen, Z.; Mao, Z.; Li, W. Targeting Hsc70-based autophagy to eliminate amyloid $\beta$ oligomers. Biochem Biophys Res Commun 2020, 524, 923-928. [CrossRef] [PubMed]

294. Majumder, S.; Richardson, A.; Strong, R.; Oddo, S. Inducing autophagy by rapamycin before, but not after, the formation of plaques and tangles ameliorates cognitive deficits. PLOS ONE 2011, 6, e25416. [CrossRef] [PubMed]

295. Bauckman, K.A.; Owusu-Boaitey, N.; Mysorekar, I.U. Selective autophagy: Xenophagy. Methods 2015, 75, 120-127. [CrossRef] [PubMed]

296. Sharma, V.; Verma, S.; Seranova, E.; Sarkar, S.; Kumar, D. Selective Autophagy and Xenophagy in Infection and Disease. Front. Cell Dev. Biol. 2018, 6, 147. [CrossRef]

297. Xu, Y.; Zhou, P.; Cheng, S.; Lu, Q.; Nowak, K.; Hopp, A.K.; Li, L.; Shi, X.; Zhou, Z.; Gao, W.; et al. A Bacterial Effector Reveals the V-ATPase-ATG16L1 Axis that Initiates Xenophagy. Cell 2019, 178, 552-566. [CrossRef]

298. Thurston, T.L.; Wandel, M.P.; von Muhlinen, N.; Foeglein, A.; Randow, F. Galectin 8 targets damaged vesicles for autophagy to defend cells against bacterial invasion. Nature 2012, 482, 414-418. [CrossRef] [PubMed]

299. Watson, R.O.; Manzanillo, P.S.; Cox, J.S. Extracellular M. tuberculosis DNA targets bacteria for autophagy by activating the host DNA-sensing pathway. Cell 2012, 150, 803-815. [CrossRef]

300. Chai, Q.; Wang, X.; Qiang, L.; Zhang, Y.; Ge, P.; Lu, Z.; Zhong, Y.; Li, B.; Wang, J.; Zhang, L.; et al. A Mycobacterium tuberculosis surface protein recruits ubiquitin to trigger host xenophagy. Nat. Commun. 2019, 10, 1973. [CrossRef]

301. Nakagawa, I.; Amano, A.; Mizushima, N.; Yamamoto, A.; Yamaguchi, H.; Kamimoto, T.; Nara, A.; Funao, J.; Nakata, M.; Tsuda, K.; et al. Autophagy defends cells against invading group A Streptococcus. Science 2004, 306, 1037-1040. [CrossRef]

302. Sakurai, A.; Maruyama, F.; Funao, J.; Nozawa, T.; Aikawa, C.; Okahashi, N.; Shintani, S.; Hamada, S.; Ooshima, T.; Nakagawa, I. Specific behavior of intracellular Streptococcus pyogenes that has undergone autophagic degradation is associated with bacterial streptolysin O and host small G proteins Rab5 and Rab7. J. Biol. Chem. 2010, 285, 22666-22675. [CrossRef] [PubMed]

303. Nozawa, T.; Aikawa, C.; Goda, A.; Maruyama, F.; Hamada, S.; Nakagawa, I. The small GTPases Rab9A and Rab23 function at distinct steps in autophagy during Group A Streptococcus infection. Cell Microbiol. 2012, 14, 1149-1165. [CrossRef]

304. Losier, T.T.; Akuma, M.; McKee-Muir, O.C.; LeBlond, N.D.; Suk, Y.; Alsaadi, R.M.; Guo, Z.; Reshke, R.; Sad, S.; Campbell-Valois, F.X.; et al. AMPK Promotes Xenophagy through Priming of Autophagic Kinases upon Detection of Bacterial Outer Membrane Vesicles. Cell Rep. 2019, 26, 2150-2165. [CrossRef]

305. Ganesan, R.; Hos, N.J.; Gutierrez, S.; Fischer, J.; Stepek, J.M.; Daglidu, E.; Krönke, M.; Robinson, N. Salmonella Typhimurium disrupts Sirt1/AMPK checkpoint control of mTOR to impair autophagy. PLoS Pathog. 2017, 13, e1006227. [CrossRef]

306. Choy, A.; Dancourt, J.; Mugo, B.; O'Connor, T.J.; Isberg, R.R.; Melia, T.J.; Roy, C.R. The Legionella effector RavZ inhibits host autophagy through irreversible Atg8 deconjugation. Science 2012, 338, 1072-1076. [CrossRef]

307. Dong, N.; Zhu, Y.; Lu, Q.; Hu, L.; Zheng, Y.; Shao, F. Structurally distinct bacterial TBC-like GAPs link Arf GTPase to Rab1 inactivation to counteract host defenses. Cell 2012, 150, 1029-1041. [CrossRef] 
308. Ao, X.; Zou, L.; Wu, Y. Regulation of autophagy by the Rab GTPase network. Cell Death Differ. 2014, 21, 348-358. [CrossRef]

309. Feng, Z.Z.; Jiang, A.J.; Mao, A.W.; Feng, Y.; Wang, W.; Li, J.; Zhang, X.; Xing, K.; Peng, X. The. J. Biol. Chem. 2018, $293,9662-9673$. [CrossRef]

310. Romagnoli, A.; Etna, M.P.; Giacomini, E.; Pardini, M.; Remoli, M.E.; Corazzari, M.; Falasca, L.; Goletti, D.; Gafa, V.; Simeone, R.; et al. ESX-1 dependent impairment of autophagic flux by Mycobacterium tuberculosis in human dendritic cells. Autophagy 2012, 8, 1357-1370. [CrossRef]

311. Raju, D.; Hussey, S.; Ang, M.; Terebiznik, M.R.; Sibony, M.; Galindo-Mata, E.; Gupta, V.; Blanke, S.R.; Delgado, A.; Romero-Gallo, J.; et al. Vacuolating cytotoxin and variants in Atg16L1 that disrupt autophagy promote Helicobacter pylori infection in humans. Gastroenterology 2012, 142, 1160-1171. [CrossRef]

312. Huang, J.; Brumell, J.H. Bacteria-autophagy interplay: a battle for survival. Nat. Rev. Microbiol. 2014, 12, 101-114. [CrossRef] [PubMed]

313. Ahmad, L.; Mostowy, S.; Sancho-Shimizu, V. Autophagy-Virus Interplay: From Cell Biology to Human Disease. Front. Cell Dev. Biol. 2018, 6, 155. [CrossRef]

314. Staring, J.; von Castelmur, E.; Blomen, V.A.; van den Hengel, L.G.; Brockmann, M.; Baggen, J.; Thibaut, H.J.; Nieuwenhuis, J.; Janssen, H.; van Kuppeveld, F.J.; et al. PLA2G16 represents a switch between entry and clearance of Picornaviridae. Nature 2017, 541, 412-416. [CrossRef] [PubMed]

315. Kim, N.; Kim, M.J.; Sung, P.S.; Bae, Y.C.; Shin, E.C.; Yoo, J.Y. Interferon-inducible protein SCOTIN interferes with HCV replication through the autolysosomal degradation of NS5A. Nat. Commun. 2016, 7, 10631. [CrossRef] [PubMed]

316. Choi, Y.; Bowman, J.W.; Jung, J.U. Autophagy during viral infection - a double-edged sword. Nat. Rev. Microbiol. 2018, 16, 341-354. [CrossRef]

317. Jackson, W.T.; Giddings, T.H.; Taylor, M.P.; Mulinyawe, S.; Rabinovitch, M.; Kopito, R.R.; Kirkegaard, K. Subversion of cellular autophagosomal machinery by RNA viruses. PLoS Biol. 2005, 3, e156. [CrossRef]

318. Guévin, C.; Manna, D.; Bélanger, C.; Konan, K.V.; Mak, P.; Labonté, P. Autophagy protein ATG5 interacts transiently with the hepatitis C virus RNA polymerase (NS5B) early during infection. Virology 2010, 405, 1-7. [CrossRef] [PubMed]

319. Wang, L.; Tian, Y.; Ou, J.H. HCV induces the expression of Rubicon and UVRAG to temporally regulate the maturation of autophagosomes and viral replication. PLoS Pathog. 2015, 11, e1004764. [CrossRef]

320. Zhou, Z.; Jiang, X.; Liu, D.; Fan, Z.; Hu, X.; Yan, J.; Wang, M.; Gao, G.F. Autophagy is involved in influenza A virus replication. Autophagy 2009, 5, 321-328. [CrossRef]

321. Zhao, Z.; Lu, K.; Mao, B.; Liu, S.; Trilling, M.; Huang, A.; Lu, M.; Lin, Y. The interplay between emerging human coronavirus infections and autophagy. Emerg. Microbes. Infect. 2021, 10, 196-205. [CrossRef]

322. Carmona-Gutierrez, D.; Bauer, M.A.; Zimmermann, A.; Kainz, K.; Hofer, S.J.; Kroemer, G.; Madeo, F. Digesting the crisis: Autophagy and coronaviruses. Microb. Cell 2020, 7, 119-128. [CrossRef] [PubMed]

323. Chen, X.; Wang, K.; Xing, Y.; Tu, J.; Yang, X.; Zhao, Q.; Li, K.; Chen, Z. Coronavirus membrane-associated papain-like proteases induce autophagy through interacting with Beclin1 to negatively regulate antiviral innate immunity. Protein Cell 2014, 5, 912-927. [CrossRef]

324. Gassen, N.C.; Niemeyer, D.; Muth, D.; Corman, V.M.; Martinelli, S.; Gassen, A.; Hafner, K.; Papies, J.; Mösbauer, K.; Zellner, A.; et al. SKP2 attenuates autophagy through Beclin1-ubiquitination and its inhibition reduces MERS-Coronavirus infection. Nat. Commun. 2019, 10, 5770. [CrossRef] [PubMed]

325. Delorme-Axford, E.; Klionsky, D.J. Highlights in the fight against COVID-19: Does autophagy play a role in SARS-CoV-2 infection? Autophagy 2020, 16, 2123-2127. [CrossRef]

326. Brest, P.; Benzaquen, J.; Klionsky, D.J.; Hofman, P.; Mograbi, B. Open questions for harnessing autophagy-modulating drugs in the SARS-CoV-2 war: Hope or hype? Autophagy 2020, 16, 2267-2270. [CrossRef]

327. Singh, K.; Chen, Y.C.; Hassanzadeh, S.; Han, K.; Judy, J.T.; Seifuddin, F.; Tunc, I.; Sack, M.N.; Pirooznia, M. Network Analysis and Transcriptome Profiling Identify Autophagic and Mitochondrial Dysfunctions in SARS-CoV-2 Infection. Front Genet. 2021, 12, 599261. [CrossRef] [PubMed]

328. Stukalov, A.; Girault, V.; Grass, V.; Karayel, O.; Bergant, V.; Urban, C.; Haas, D.A.; Huang, Y.; Oubraham, L.; Wang, A.; et al. Multilevel proteomics reveals host perturbations by SARS-CoV-2 and SARS-CoV. Nature 2021, 594, 246-252. [CrossRef]

329. Hayn, M.; Hirschenberger, M.; Koepke, L.; Nchioua, R.; Straub, J.H.; Klute, S.; Hunszinger, V.; Zech, F.; Prelli Bozzo, C.; Aftab, W.; et al. Systematic functional analysis of SARS-CoV-2 proteins uncovers viral innate immune antagonists and remaining vulnerabilities. Cell Rep. 2021, 35, 109126. [CrossRef]

330. Miao, G.; Zhao, H.; Li, Y.; Ji, M.; Chen, Y.; Shi, Y.; Bi, Y.; Wang, P.; Zhang, H. ORF3a of the COVID-19 virus SARS-CoV-2 blocks HOPS complex-mediated assembly of the SNARE complex required for autolysosome formation. Dev. Cell 2021, 56, 427-442. [CrossRef] [PubMed]

331. Zhang, Y.; Sun, H.; Pei, R.; Mao, B.; Zhao, Z.; Li, H.; Lin, Y.; Lu, K. The SARS-CoV-2 protein ORF3a inhibits fusion of autophagosomes with lysosomes. Cell Discov. 2021, 7, 31. [CrossRef]

332. Qu, Y.; Wang, X.; Zhu, Y.; Wang, W.; Wang, Y.; Hu, G.; Liu, C.; Li, J.; Ren, S.; Xiao, M.Z.X.; et al. ORF3a-Mediated Incomplete Autophagy Facilitates Severe Acute Respiratory Syndrome Coronavirus-2 Replication. Front Cell. Dev. Biol. 2021, 9, 716208. [CrossRef] 
333. Wang, R.; Simoneau, C.R.; Kulsuptrakul, J.; Bouhaddou, M.; Travisano, K.A.; Hayashi, J.M.; Carlson-Stevermer, J.; Zengel, J.R.; Richards, C.M.; Fozouni, P.; et al. Genetic Screens Identify Host Factors for SARS-CoV-2 and Common Cold Coronaviruses. Cell 2021, 184, 106-119. [CrossRef]

334. Daniloski, Z.; Jordan, T.X.; Wessels, H.H.; Hoagland, D.A.; Kasela, S.; Legut, M.; Maniatis, S.; Mimitou, E.P.; Lu, L.; Geller, E.; et al. Identification of Required Host Factors for SARS-CoV-2 Infection in Human Cells. Cell 2021, 184, 92-105. [CrossRef]

335. Schneider, W.M.; Luna, J.M.; Hoffmann, H.H.; Sánchez-Rivera, F.J.; Leal, A.A.; Ashbrook, A.W.; Le Pen, J.; Ricardo-Lax, I.; Michailidis, E.; Peace, A.; et al. Genome-Scale Identification of SARS-CoV-2 and Pan-coronavirus Host Factor Networks. Cell 2021, 184, 120-132. [CrossRef] [PubMed]

336. Bailey, A.L.; Diamond, M.S. A Crisp(r) New Perspective on SARS-CoV-2 Biology. Cell 2021, 184, 15-17. [CrossRef]

337. Yuen, C.K.; Wong, W.M.; Mak, L.F.; Wang, X.; Chu, H.; Yuen, K.Y.; Kok, K.H. Suppression of SARS-CoV-2 infection in ex-vivo human lung tissues by targeting class III phosphoinositide 3-kinase. J. Med. Virol. 2021, 93, 2076-2083. [CrossRef]

338. Trimarco, J.D.; Heaton, B.E.; Chaparian, R.R.; Burke, K.N.; Binder, R.A.; Gray, G.C.; Smith, C.M.; Menachery, V.D.; Heaton, N.S. TMEM41B is a host factor required for the replication of diverse coronaviruses including SARS-CoV-2. PLoS Pathog. 2021, 17, e1009599. [CrossRef]

339. Morita, K.; Hama, Y.; Izume, T.; Tamura, N.; Ueno, T.; Yamashita, Y.; Sakamaki, Y.; Mimura, K.; Morishita, H.; Shihoya, W.; et al. Genome-wide CRISPR screen identifies. J. Cell Biol. 2018, 217, 3817-3828. [CrossRef] [PubMed]

340. Moretti, F.; Bergman, P.; Dodgson, S.; Marcellin, D.; Claerr, I.; Goodwin, J.M.; DeJesus, R.; Kang, Z.; Antczak, C.; Begue, D.; et al. TMEM41B is a novel regulator of autophagy and lipid mobilization. EMBO Rep. 2018, 19. [CrossRef]

341. Shoemaker, C.J.; Huang, T.Q.; Weir, N.R.; Polyakov, N.J.; Schultz, S.W.; Denic, V. CRISPR screening using an expanded toolkit of autophagy reporters identifies TMEM41B as a novel autophagy factor. PLoS Biol. 2019, 17, e2007044. [CrossRef]

342. Snijder, E.J.; Limpens, R.W.A.L.; de Wilde, A.H.; de Jong, A.W.M.; Zevenhoven-Dobbe, J.C.; Maier, H.J.; Faas, F.F.G.A.; Koster, A.J.; Bárcena, M. A unifying structural and functional model of the coronavirus replication organelle: Tracking down RNA synthesis. PLoS Biol. 2020, 18, e3000715. [CrossRef]

343. Wolff, G.; Limpens, R.W.A.L.; Zevenhoven-Dobbe, J.C.; Laugks, U.; Zheng, S.; de Jong, A.W.M.; Koning, R.I.; Agard, D.A.; Grünewald, K.; Koster, A.J.; et al. A molecular pore spans the double membrane of the coronavirus replication organelle. Science 2020, 369, 1395-1398. [CrossRef]

344. Mészáros, B.; Sámano-Sánchez, H.; Alvarado-Valverde, J.; Čalyševa, J.; Martínez-Pérez, E.; Alves, R.; Shields, D.C.; Kumar, M.; Rippmann, F.; Chemes, L.B.; et al. Short linear motif candidates in the cell entry system used by SARS-CoV-2 and their potential therapeutic implications. Sci. Signal 2021, 14, abd0334. [CrossRef]

345. Liu, J.; Cao, R.; Xu, M.; Wang, X.; Zhang, H.; Hu, H.; Li, Y.; Hu, Z.; Zhong, W.; Wang, M. Hydroxychloroquine, a less toxic derivative of chloroquine, is effective in inhibiting SARS-CoV-2 infection in vitro. Cell Discov. 2020, 6, 16. [CrossRef]

346. Wang, M.; Cao, R.; Zhang, L.; Yang, X.; Liu, J.; Xu, M.; Shi, Z.; Hu, Z.; Zhong, W.; Xiao, G. Remdesivir and chloroquine effectively inhibit the recently emerged novel coronavirus (2019-nCoV) in vitro. Cell Res. 2020, 30, 269-271. [CrossRef] [PubMed]

347. Hui, X.; Zhang, L.; Cao, L.; Huang, K.; Zhao, Y.; Zhang, Y.; Chen, X.; Lin, X.; Chen, M.; Jin, M. SARS-CoV-2 promote autophagy to suppress type I interferon response. Signal Transduct. Target Ther. 2021, 6, 180. [CrossRef]

348. Zhang, Y.; Chen, Y.; Li, Y.; Huang, F.; Luo, B.; Yuan, Y.; Xia, B.; Ma, X.; Yang, T.; Yu, F.; et al. The ORF8 protein of SARS-CoV-2 mediates immune evasion through down-regulating MHC-I. Proc. Natl. Acad. Sci. USA 2021, 118, e2024202118. [CrossRef]

349. Ghosh, S.; Dellibovi-Ragheb, T.A.; Kerviel, A.; Pak, E.; Qiu, Q.; Fisher, M.; Takvorian, P.M.; Bleck, C.; Hsu, V.W.; Fehr, A.R.; et al. $\beta$-Coronaviruses Use Lysosomes for Egress Instead of the Biosynthetic Secretory Pathway. Cell 2020, 183, 1520-1535. [CrossRef]

350. Gassen, N.C.; Papies, J.; Bajaj, T.; Emanuel, J.; Dethloff, F.; Chua, R.L.; Trimpert, J.; Heinemann, N.; Niemeyer, C.; Weege, F.; et al. SARS-CoV-2-mediated dysregulation of metabolism and autophagy uncovers host-targeting antivirals. Nat. Commun. 2021, 12, 3818. [CrossRef] [PubMed]

351. Zhang, Y.; Sowers, J.R.; Ren, J. Targeting autophagy in obesity: From pathophysiology to management. Nat. Rev. Endocrinol. 2018, 14, 356-376. [CrossRef] [PubMed]

352. Yang, L.; Li, P.; Fu, S.; Calay, E.S.; Hotamisligil, G.S. Defective hepatic autophagy in obesity promotes ER stress and causes insulin resistance. Cell Metab. 2010, 11, 467-478. [CrossRef] [PubMed]

353. López-Vicario, C.; Alcaraz-Quiles, J.; García-Alonso, V.; Rius, B.; Hwang, S.H.; Titos, E.; Lopategi, A.; Hammock, B.D.; Arroyo, V.; Clària, J. Inhibition of soluble epoxide hydrolase modulates inflammation and autophagy in obese adipose tissue and liver: Role for omega-3 epoxides. Proc. Natl. Acad. Sci. USA 2015, 112, 536-541. [CrossRef]

354. Kovsan, J.; Blüher, M.; Tarnovscki, T.; Klöting, N.; Kirshtein, B.; Madar, L.; Shai, I.; Golan, R.; Harman-Boehm, I.; Schön, M.R.; et al. Altered autophagy in human adipose tissues in obesity. J. Clin. Endocrinol. Metab. 2011, 96, E268-E277. [CrossRef] [PubMed]

355. Kosacka, J.; Kern, M.; Klöting, N.; Paeschke, S.; Rudich, A.; Haim, Y.; Gericke, M.; Serke, H.; Stumvoll, M.; Bechmann, I.; et al. Autophagy in adipose tissue of patients with obesity and type 2 diabetes. Mol. Cell Endocrinol. 2015, 409, 21-32. [CrossRef] [PubMed]

356. Aijälä, M.; Malo, E.; Ukkola, O.; Bloigu, R.; Lehenkari, P.; Autio-Harmainen, H.; Santaniemi, M.; Kesäniemi, Y.A. Long-term fructose feeding changes the expression of leptin receptors and autophagy genes in the adipose tissue and liver of male rats: A possible link to elevated triglycerides. Genes Nutr. 2013, 8, 623-635. [CrossRef] [PubMed]

357. Ahmed, M.; Nguyen, H.Q.; Hwang, J.S.; Zada, S.; Lai, T.H.; Kang, S.S.; Kim, D.R. Systematic characterization of autophagy-related genes during the adipocyte differentiation using public-access data. Oncotarget 2018, 9, 15526-15541. [CrossRef] [PubMed] 
358. Baerga, R.; Zhang, Y.; Chen, P.H.; Goldman, S.; Jin, S. Targeted deletion of autophagy-related 5 (atg5) impairs adipogenesis in a cellular model and in mice. Autophagy 2009, 5, 1118-1130. [CrossRef]

359. Zhang, C.; He, Y.; Okutsu, M.; Ong, L.C.; Jin, Y.; Zheng, L.; Chow, P.; Yu, S.; Zhang, M.; Yan, Z. Autophagy is involved in adipogenic differentiation by repressesing proteasome-dependent PPAR 2 degradation. Am. J. Physiol. Endocrinol. Metab. 2013, 305, E530-E539. [CrossRef]

360. Guo, L.; Huang, J.X.; Liu, Y.; Li, X.; Zhou, S.R.; Qian, S.W.; Zhu, H.; Huang, H.Y.; Dang, Y.J.; Tang, Q.Q. Transactivation of Atg4b by C/EBP $\beta$ promotes autophagy to facilitate adipogenesis. Mol. Cell Biol. 2013, 33, 3180-3190. [CrossRef]

361. He, B.; Wang, X.; Jin, X.; Xue, Z.; Zhu, J.; Wang, C.; Jin, Y.; Fu, Z. $\beta$-Cypermethrin promotes the adipogenesis of 3T3-L1 cells via inducing autophagy and shaping an adipogenesis-friendly microenvironment. Acta Biochim. Biophys. Sin. 2020, 52, 821-831. [CrossRef] [PubMed]

362. Skop, V.; Cahova, M.; Dankova, H.; Papackova, Z.; Palenickova, E.; Svoboda, P.; Zidkova, J.; Kazdova, L. Autophagy inhibition in early but not in later stages prevents 3T3-L1 differentiation: Effect on mitochondrial remodeling. Differentiation 2014, 87, 220-229. [CrossRef] [PubMed]

363. Yamamuro, T.; Kawabata, T.; Fukuhara, A.; Saita, S.; Nakamura, S.; Takeshita, H.; Fujiwara, M.; Enokidani, Y.; Yoshida, G.; Tabata, K.; et al. Age-dependent loss of adipose Rubicon promotes metabolic disorders via excess autophagy. Nat. Commun. 2020, 11, 4150. [CrossRef]

364. Zoico, E.; Rubele, S.; De Caro, A.; Nori, N.; Mazzali, G.; Fantin, F.; Rossi, A.; Zamboni, M. Brown and Beige Adipose Tissue and Aging. Front. Endocrinol. (Lausanne) 2019, 10, 368. [CrossRef] [PubMed]

365. Altshuler-Keylin, S.; Shinoda, K.; Hasegawa, Y.; Ikeda, K.; Hong, H.; Kang, Q.; Yang, Y.; Perera, R.M.; Debnath, J.; Kajimura, S. Beige Adipocyte Maintenance Is Regulated by Autophagy-Induced Mitochondrial Clearance. Cell Metab. 2016, 24, 402-419. [CrossRef]

366. Deng, J.; Guo, Y.; Yuan, F.; Chen, S.; Yin, H.; Jiang, X.; Jiao, F.; Wang, F.; Ji, H.; Hu, G.; et al. Autophagy inhibition prevents glucocorticoid-increased adiposity via suppressing BAT whitening. Autophagy 2020, 16, 451-465. [CrossRef] [PubMed]

367. Lu, X.; Altshuler-Keylin, S.; Wang, Q.; Chen, Y.; Henrique Sponton, C.; Ikeda, K.; Maretich, P.; Yoneshiro, T.; Kajimura, S. Mitophagy controls beige adipocyte maintenance through a Parkin-dependent and UCP1-independent mechanism. Sci. Signal 2018, 11. [CrossRef]

368. Taylor, D.; Gottlieb, R.A. Parkin-mediated mitophagy is downregulated in browning of white adipose tissue. Obesity 2017, 25, 704-712. [CrossRef]

369. Cairó, M.; Villarroya, J.; Cereijo, R.; Campderrós, L.; Giralt, M.; Villarroya, F. Thermogenic activation represses autophagy in brown adipose tissue. Int. J. Obes. 2016, 40, 1591-1599. [CrossRef]

370. Ro, S.H.; Jang, Y.; Bae, J.; Kim, I.M.; Schaecher, C.; Shomo, Z.D. Autophagy in Adipocyte Browning: Emerging Drug Target for Intervention in Obesity. Front Physiol. 2019, 10, 22. [CrossRef] [PubMed]

371. Lim, Y.M.; Lim, H.; Hur, K.Y.; Quan, W.; Lee, H.Y.; Cheon, H.; Ryu, D.; Koo, S.H.; Kim, H.L.; Kim, J.; et al. Systemic autophagy insufficiency compromises adaptation to metabolic stress and facilitates progression from obesity to diabetes. Nat. Commun. 2014, 5, 4934. [CrossRef]

372. Liu, Y.; Takahashi, Y.; Desai, N.; Zhang, J.; Serfass, J.M.; Shi, Y.G.; Lynch, C.J.; Wang, H.G. Bif-1 deficiency impairs lipid homeostasis and causes obesity accompanied by insulin resistance. Sci. Rep. 2016, 6, 20453. [CrossRef]

373. He, C.; Wei, Y.; Sun, K.; Li, B.; Dong, X.; Zou, Z.; Liu, Y.; Kinch, L.N.; Khan, S.; Sinha, S.; et al. Beclin 2 functions in autophagy, degradation of $G$ protein-coupled receptors, and metabolism. Cell 2013, 154, 1085-1099. [CrossRef] [PubMed]

374. Fernández, Á.; Bárcena, C.; Martínez-García, G.G.; Tamargo-Gómez, I.; Suárez, M.F.; Pietrocola, F.; Castoldi, F.; Esteban, L.; Sierra-Filardi, E.; Boya, P.; et al. Autophagy couteracts weight gain, lipotoxicity and pancreatic $\beta$-cell death upon hypercaloric pro-diabetic regimens. Cell. Death. Dis. 2017, 8, e2970. [CrossRef] [PubMed]

375. Pyo, J.O.; Yoo, S.M.; Ahn, H.H.; Nah, J.; Hong, S.H.; Kam, T.I.; Jung, S.; Jung, Y.K. Overexpression of Atg5 in mice activates autophagy and extends lifespan. Nat. Commun. 2013, 4, 2300. [CrossRef] [PubMed]

376. Yamamoto, S.; Kuramoto, K.; Wang, N.; Situ, X.; Priyadarshini, M.; Zhang, W.; Cordoba-Chacon, J.; Layden, B.T.; He, C. Autophagy Differentially Regulates Insulin Production and Insulin Sensitivity. Cell. Rep. 2018, 23, 3286-3299. [CrossRef]

377. Zhang, Y.; Goldman, S.; Baerga, R.; Zhao, Y.; Komatsu, M.; Jin, S. Adipose-specific deletion of autophagy-related gene 7 (atg7) in mice reveals a role in adipogenesis. Proc. Natl. Acad. Sci. USA 2009, 106, 19860-19865. [CrossRef]

378. Singh, R.; Xiang, Y.; Wang, Y.; Baikati, K.; Cuervo, A.M.; Luu, Y.K.; Tang, Y.; Pessin, J.E.; Schwartz, G.J.; Czaja, M.J. Autophagy regulates adipose mass and differentiation in mice. J.Clin. Invest. 2009, 119, 3329-3339. [CrossRef] [PubMed]

379. Wang, X.; Wu, R.; Liu, Y.; Zhao, Y.; Bi, Z.; Yao, Y.; Liu, Q.; Shi, H.; Wang, F.; Wang, Y. m6A mRNA methylation controls autophagy and adipogenesis by targeting Atg5 and Atg7. Autophagy 2020, 16, 1221-1235. [CrossRef]

380. Cai, J.; Pires, K.M.; Ferhat, M.; Chaurasia, B.; Buffolo, M.A.; Smalling, R.; Sargsyan, A.; Atkinson, D.L.; Summers, S.A.; Graham, T.E.; et al. Autophagy Ablation in Adipocytes Induces Insulin Resistance and Reveals Roles for Lipid Peroxide and Nrf2 Signaling in Adipose-Liver Crosstalk. Cell. Rep. 2018, 25, 1708-1717. [CrossRef]

381. Jin, Y.; Ji, Y.; Song, Y.; Choe, S.S.; Jeon, Y.G.; Na, H.; Nam, T.W.; Kim, H.J.; Nahmgoong, H.; Kim, S.M.; et al. Depletion of Adipocyte. Diabetes 2021, 70, 182-195. [CrossRef] [PubMed] 
382. Settembre, C.; De Cegli, R.; Mansueto, G.; Saha, P.K.; Vetrini, F.; Visvikis, O.; Huynh, T.; Carissimo, A.; Palmer, D.; Klisch, T.J.; et al. TFEB controls cellular lipid metabolism through a starvation-induced autoregulatory loop. Nat. Cell Biol. 2013, 15, 647-658. [CrossRef]

383. Jaber, N.; Dou, Z.; Chen, J.S.; Catanzaro, J.; Jiang, Y.P.; Ballou, L.M.; Selinger, E.; Ouyang, X.; Lin, R.Z.; Zhang, J.; et al. Class III PI3K Vps34 plays an essential role in autophagy and in heart and liver function. Proc. Natl. Acad. Sci. USA 2012, 109, $2003-2008$. [CrossRef] [PubMed]

384. Ebato, C.; Uchida, T.; Arakawa, M.; Komatsu, M.; Ueno, T.; Komiya, K.; Azuma, K.; Hirose, T.; Tanaka, K.; Kominami, E.; et al. Autophagy is important in islet homeostasis and compensatory increase of beta cell mass in response to high-fat diet. Cell Metab. 2008, 8, 325-332. [CrossRef] [PubMed]

385. Aoyagi, K.; Ohara-Imaizumi, M.; Itakura, M.; Torii, S.; Akimoto, Y.; Nishiwaki, C.; Nakamichi, Y.; Kishimoto, T.; Kawakami, H.; Harada, A.; et al. VAMP7 Regulates Autophagy to Maintain Mitochondrial Homeostasis and to Control Insulin Secretion in Pancreatic $\beta$-Cells. Diabetes 2016, 65, 1648-1659. [CrossRef] [PubMed]

386. Kim, K.H.; Jeong, Y.T.; Oh, H.; Kim, S.H.; Cho, J.M.; Kim, Y.N.; Kim, S.S.; Kim, D.H.; Hur, K.Y.; Kim, H.K.; et al. Autophagy deficiency leads to protection from obesity and insulin resistance by inducing Fgf21 as a mitokine. Nat. Med. 2013, 19, 83-92. [CrossRef] [PubMed]

387. Quan, W.; Kim, H.K.; Moon, E.Y.; Kim, S.S.; Choi, C.S.; Komatsu, M.; Jeong, Y.T.; Lee, M.K.; Kim, K.W.; Kim, M.S.; et al. Role of hypothalamic proopiomelanocortin neuron autophagy in the control of appetite and leptin response. Endocrinology 2012, 153, 1817-1826. [CrossRef] [PubMed]

388. Lee, H.Y.; Kim, J.; Quan, W.; Lee, J.C.; Kim, M.S.; Kim, S.H.; Bae, J.W.; Hur, K.Y.; Lee, M.S. Autophagy deficiency in myeloid cells increases susceptibility to obesity-induced diabetes and experimental colitis. Autophagy 2016, 12, 1390-1403. [CrossRef]

389. DeFronzo, R.A.; Ferrannini, E.; Groop, L.; Henry, R.R.; Herman, W.H.; Holst, J.J.; Hu, F.B.; Kahn, C.R.; Raz, I.; Shulman, G.I.; et al. Type 2 diabetes mellitus. Nat. Rev. Dis. Primers. 2015, 1, 15019. [CrossRef]

390. Yao, D.; GangYi, Y.; QiNan, W. Autophagic dysfunction of $\beta$ cell dysfunction in type 2 diabetes, a double-edged sword. Genes Dis. 2021, 8, 438-447. [CrossRef]

391. Shigihara, N.; Fukunaka, A.; Hara, A.; Komiya, K.; Honda, A.; Uchida, T.; Abe, H.; Toyofuku, Y.; Tamaki, M.; Ogihara, T.; et al. Human IAPP-induced pancreatic $\beta$ cell toxicity and its regulation by autophagy. J. Clin. Invest. 2014, 124, 3634-3644. [CrossRef]

392. Rivera, J.F.; Costes, S.; Gurlo, T.; Glabe, C.G.; Butler, P.C. Autophagy defends pancreatic $\beta$ cells from human islet amyloid polypeptide-induced toxicity. J. Clin. Investig. 2014, 124, 3489-3500. [CrossRef] [PubMed]

393. Kim, J.; Park, K.; Kim, M.J.; Lim, H.; Kim, K.H.; Kim, S.W.; Lee, E.S.; Kim, H.H.; Kim, S.J.; Hur, K.Y.; et al. An autophagy enhancer ameliorates diabetes of human IAPP-transgenic mice through clearance of amyloidogenic oligomer. Nat. Commun. 2021, 12, 183. [CrossRef] [PubMed]

394. Kong, F.J.; Wu, J.H.; Sun, S.Y.; Zhou, J.Q. The endoplasmic reticulum stress/autophagy pathway is involved in cholesterol-induced pancreatic $\beta$-cell injury. Sci. Rep. 2017, 7, 44746. [CrossRef]

395. Bugliani, M.; Mossuto, S.; Grano, F.; Suleiman, M.; Marselli, L.; Boggi, U.; De Simone, P.; Eizirik, D.L.; Cnop, M.; Marchetti, P.; et al. Modulation of Autophagy Influences the Function and Survival of Human Pancreatic Beta Cells Under Endoplasmic Reticulum Stress Conditions and in Type 2 Diabetes. Front Endocrinol. 2019, 10, 52. [CrossRef]

396. Quan, W.; Hur, K.Y.; Lim, Y.; Oh, S.H.; Lee, J.C.; Kim, K.H.; Kim, G.H.; Kim, S.W.; Kim, H.L.; Lee, M.K.; et al. Autophagy deficiency in beta cells leads to compromised unfolded protein response and progression from obesity to diabetes in mice. Diabetologia 2012, 55, 392-403. [CrossRef] [PubMed]

397. Leloup, C.; Tourrel-Cuzin, C.; Magnan, C.; Karaca, M.; Castel, J.; Carneiro, L.; Colombani, A.L.; Ktorza, A.; Casteilla, L.; Pénicaud, L. Mitochondrial reactive oxygen species are obligatory signals for glucose-induced insulin secretion. Diabetes 2009, 58, 673-681. [CrossRef]

398. Sidarala, V.; Pearson, G.L.; Parekh, V.S.; Thompson, B.; Christen, L.; Gingerich, M.A.; Zhu, J.; Stromer, T.; Ren, J.; Reck, E.C.; et al. Mitophagy protects $\beta$ cells from inflammatory damage in diabetes. JCI Insight 2020, 5, e141138. [CrossRef]

399. Bhansali, S.; Bhansali, A.; Walia, R.; Saikia, U.N.; Dhawan, V. Alterations in Mitochondrial Oxidative Stress and Mitophagy in Subjects with Prediabetes and Type 2 Diabetes Mellitus. Front Endocrinol. 2017, 8, 347. [CrossRef]

400. Hoshino, A.; Ariyoshi, M.; Okawa, Y.; Kaimoto, S.; Uchihashi, M.; Fukai, K.; Iwai-Kanai, E.; Ikeda, K.; Ueyama, T.; Ogata, T.; et al. Inhibition of p53 preserves Parkin-mediated mitophagy and pancreatic $\beta$-cell function in diabetes. Proc. Natl. Acad. Sci. USA 2014, 111, 3116-3121. [CrossRef]

401. Hernández, M.G.; Aguilar, A.G.; Burillo, J.; Oca, R.G.; Manca, M.A.; Novials, A.; Alcarraz-Vizan, G.; Guillén, C.; Benito, M. Pancreatic $\beta$ cells overexpressing hIAPP impaired mitophagy and unbalanced mitochondrial dynamics. Cell Death Dis. 2018, 9, 481. [CrossRef] [PubMed]

402. Soleimanpour, S.A.; Ferrari, A.M.; Raum, J.C.; Groff, D.N.; Yang, J.; Kaufman, B.A.; Stoffers, D.A. Diabetes Susceptibility Genes Pdx1 and Clec16a Function in a Pathway Regulating Mitophagy in $\beta$-Cells. Diabetes 2015, 64, 3475-3484. [CrossRef] [PubMed]

403. Fujimoto, K.; Polonsky, K.S. Pdx1 and other factors that regulate pancreatic beta-cell survival. Diabetes Obes. Metab. 2009, 11 (Suppl. 4), 30-37. [CrossRef]

404. Guo, T.; Liu, T.; Sun, Y.; Liu, X.; Xiong, R.; Li, H.; Li, Z.; Zhang, Z.; Tian, Z.; Tian, Y. Sonodynamic therapy inhibits palmitateinduced beta cell dysfunction via PINK1/Parkin-dependent mitophagy. Cell Death Dis. 2019, 10, 457. [CrossRef] [PubMed] 
405. Muralidharan, C.; Conteh, A.M.; Marasco, M.R.; Crowder, J.J.; Kuipers, J.; de Boer, P.; Linnemann, A.K. Pancreatic beta cell autophagy is impaired in type 1 diabetes. Diabetologia 2021, 64, 865-877. [CrossRef]

406. Liu, Y.; Palanivel, R.; Rai, E.; Park, M.; Gabor, T.V.; Scheid, M.P.; Xu, A.; Sweeney, G. Adiponectin stimulates autophagy and reduces oxidative stress to enhance insulin sensitivity during high-fat diet feeding in mice. Diabetes 2015, 64, 36-48. [CrossRef] [PubMed]

407. Wang, H.; Zhu, Y.Y.; Wang, L.; Teng, T.; Zhou, M.; Wang, S.G.; Tian, Y.Z.; Du, L.; Yin, X.X.; Sun, Y. Mangiferin ameliorates fatty liver via modulation of autophagy and inflammation in high-fat-diet induced mice. Biomed. Pharmacother. 2017, 96, 328-335. [CrossRef] [PubMed]

408. He, Q.; Sha, S.; Sun, L.; Zhang, J.; Dong, M. GLP-1 analogue improves hepatic lipid accumulation by inducing autophagy via AMPK/mTOR pathway. Biochem. Biophys. Res. Commun. 2016, 476, 196-203. [CrossRef] [PubMed]

409. Lim, H.; Lim, Y.M.; Kim, K.H.; Jeon, Y.E.; Park, K.; Kim, J.; Hwang, H.Y.; Lee, D.J.; Pagire, H.; Kwon, H.J.; et al. A novel autophagy enhancer as a therapeutic agent against metabolic syndrome and diabetes. Nat. Commun. 2018, 9, 1438. [CrossRef] [PubMed]

410. Qiao, X.; Zhou, Z.C.; Niu, R.; Su, Y.T.; Sun, Y.; Liu, H.L.; Teng, J.L.; Ye, J.N.; Shi, H.; Yang, C.D.; et al. Hydroxychloroquine Improves Obesity-Associated Insulin Resistance and Hepatic Steatosis by Regulating Lipid Metabolism. Front. Pharmacol. 2019, 10, 855. [CrossRef]

411. Wasko, M.C.; McClure, C.K.; Kelsey, S.F.; Huber, K.; Orchard, T.; Toledo, F.G. Antidiabetogenic effects of hydroxychloroquine on insulin sensitivity and beta cell function: A randomised trial. Diabetologia 2015, 58, 2336-2343. [CrossRef] [PubMed]

412. Kounakis, K.; Chaniotakis, M.; Markaki, M.; Tavernarakis, N. Emerging Roles of Lipophagy in Health and Disease. Front. Cell Dev. Biol. 2019, 7, 185. [CrossRef]

413. Fu, Y.; Chen, N.; Wang, Z.; Luo, S.; Ding, Y.; Lu, B. Degradation of lipid droplets by chimeric autophagy-tethering compounds. Cell Res. 2021, 31, 965-979. [CrossRef]

414. Baumeier, C.; Kaiser, D.; Heeren, J.; Scheja, L.; John, C.; Weise, C.; Eravci, M.; Lagerpusch, M.; Schulze, G.; Joost, H.G.; et al. Caloric restriction and intermittent fasting alter hepatic lipid droplet proteome and diacylglycerol species and prevent diabetes in NZO mice. Biochim. Biophys. Acta 2015, 1851, 566-576. [CrossRef] [PubMed]

415. Anson, R.M.; Guo, Z.; de Cabo, R.; Iyun, T.; Rios, M.; Hagepanos, A.; Ingram, D.K.; Lane, M.A.; Mattson, M.P. Intermittent fasting dissociates beneficial effects of dietary restriction on glucose metabolism and neuronal resistance to injury from calorie intake. Proc. Natl. Acad. Sci. USA 2003, 100, 6216-6220. [CrossRef]

416. Sutton, E.F.; Beyl, R.; Early, K.S.; Cefalu, W.T.; Ravussin, E.; Peterson, C.M. Early Time-Restricted Feeding Improves Insulin Sensitivity, Blood Pressure, and Oxidative Stress Even without Weight Loss in Men with Prediabetes. Cell Metab. 2018, 27, 1212-1221. [CrossRef] [PubMed]

417. Byun, S.; Seok, S.; Kim, Y.C.; Zhang, Y.; Yau, P.; Iwamori, N.; Xu, H.E.; Ma, J.; Kemper, B.; Kemper, J.K. Fasting-induced FGF21 signaling activates hepatic autophagy and lipid degradation via JMJD3 histone demethylase. Nat. Commun. 2020, $11,807$. [CrossRef] [PubMed]

418. Liu, H.; Javaheri, A.; Godar, R.J.; Murphy, J.; Ma, X.; Rohatgi, N.; Mahadevan, J.; Hyrc, K.; Saftig, P.; Marshall, C.; et al. Intermittent fasting preserves beta-cell mass in obesity-induced diabetes via the autophagy-lysosome pathway. Autophagy 2017, 13, 1952-1968. [CrossRef]

419. Martinez-Lopez, N.; Tarabra, E.; Toledo, M.; Garcia-Macia, M.; Sahu, S.; Coletto, L.; Batista-Gonzalez, A.; Barzilai, N.; Pessin, J.E.; Schwartz, G.J.; et al. System-wide Benefits of Intermeal Fasting by Autophagy. Cell Metab. 2017, 26, 856-871. [CrossRef] [PubMed]

420. Khandia, R.; Dadar, M.; Munjal, A.; Dhama, K.; Karthik, K.; Tiwari, R.; Yatoo, M.I.; Iqbal, H.M.N.; Singh, K.P.; Joshi, S.K.; et al. A Comprehensive Review of Autophagy and Its Various Roles in Infectious, Non-Infectious, and Lifestyle Diseases: Current Knowledge and Prospects for Disease Prevention, Novel Drug Design, and Therapy. Cells 2019, 8, 674. [CrossRef]

421. Klionsky, D.J.; Abdel-Aziz, A.K.; Abdelfatah, S.; Abdellatif, M.; Abdoli, A.; Abel, S.; Abeliovich, H.; Abildgaard, M.H.; Abudu, Y.P.; Acevedo-Arozena, A.; et al. Guidelines for the use and interpretation of assays for monitoring autophagy (4th edition). Autophagy 2021, 17, 1-382. [CrossRef] [PubMed] 